\title{
AVALIAÇÃO DA RESISTÊNCIA À MICRO-TRAÇÃO DE REPAROS EM RESINA COMPOSTA, UTILIZANDO-SE DIFERENTES TRATAMENTOS DE SUPERFÍCIE
}

RODRIGO RICHARD DA SILVEIRA

Tese apresentada à Faculdade de Odontologia de Bauru, da Universidade de São Paulo, como parte dos requisitos para obtenção do título de Doutor em Odontologia - área de Dentística, opção Materiais Dentários

(Edição revisada)

\section{BAURU}




\section{AVALIAÇÃO DA RESISTÊNCIA À MICRO-TRAÇÃO DE REPAROS EM RESINA COMPOSTA, UTILIZANDO-SE DIFERENTES TRATAMENTOS DE SUPERFÍCIE}

RODRIGO RICHARD DA SILVEIRA

Tese apresentada à Faculdade de Odontologia de Bauru, da Universidade de São Paulo, como parte dos requisitos para obtenção do título de Doutor em Odontologia - área de Dentística, opção Materiais Dentários

Orientador: Prof. Dr. Paulo Afonso

Silveira Francisconi

\section{BAURU}




\section{Silveira, Rodrigo Richard da}

Si39a Avaliação da resistência à micro-tração de reparos em resina composta, utilizando-se diferentes tratamentos de superfície / Rodrigo Richard da Silveira. -- Bauru, 2003.

122 p. : il. ; $29,7 \mathrm{~cm}$

Tese. (Doutorado) -- Faculdade de Odontologia de Bauru. USP. Orientador: Prof. Dr. Paulo Afonso Silveira Francisconi.

Autorizo, exclusivamente para fins acadêmicos e científicos, a reprodução total ou parcial desta tese, através de processos fotocopiadores e/ou meios eletrônicos.

Assinatura do autor:

Data: 


\section{RODRIGO RICHARD DA SILVEIRA}

Filiação

Naturalidade

Nascimento

$1991-1995$

$1997-1998$

$1999-2003$

2001

Associações
Bolivar Boanerges da Silveira e Maria Enedina Carvalhais da Silveira.

Belo Horizonte - MG.

16 de outubro de 1971.

Graduação - Faculdade de Odontologia da Universidade Federal de Minas Gerais - UFMG.

Curso de Pós-Graduação, área de Dentística, opção Materiais Dentários, nível de Mestrado, na Faculdade de Odontologia de Bauru - Universidade de São Paulo.

Curso de Pós-Graduação, área de Dentística, opção Materiais Dentários, nível de Doutorado, na Faculdade de Odontologia de Bauru - Universidade de São Paulo.

Professor e Coordenador do Curso de Odontologia do Centro Universitário Newton Paiva (BH - MG).

- Associação Brasileira de Odontologia de Minas Gerais.

- Associação de Pós-Graduação da Faculdade de Odontologia de Bauru - USP.

- Grupo Brasileiro de Professores de Materiais Dentários.

- Grupo Brasileiro dos Professores de Dentística.

- IADR - International Association for Dental Research 
Este fruto só pode ser dedicado a uma pessoa: Bolivar Boanerges da Silveira, pai de Bernardo, Rodrigo, Isabela e marido de Enedina.

A cada dia que passa admiro mais ainda o legado deixado pelo meu pai que partiu no dia 02 de julho de 2002. Espelho-me nas suas ações, no seu modo de ser em todos os momentos. Agora compreendo todo o significado da palavra saudade... mas também efetivamente continuo a compreender os significados das palavras honestidade, honradez, justiça, amor, educação e inteligência. Pois respirei e vivi todos estes significados durante 30 anos de convivência com Bolivar Boanerges da Silveira, meu pai.

Peço desculpas à minha família, meus amigos, meu orientador, à FOB -USP, ao Centro Universitário Newton Paiva, à CAPES e a todos que por um motivo 
ou outro contribuíram para a efetivação deste trabalho por ter feito uma dedicatória exclusiva.

Que Deus abençoe àqueles que auxiliaram-me na confecção desta tese de doutorado. 


\section{SUMÁRIO}

LISTA DE ABREVIATURAS, SIGLAS E SÍMBOLOS ...................................................... vii

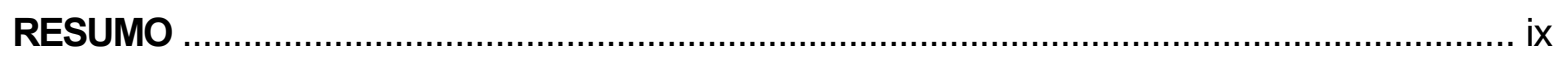

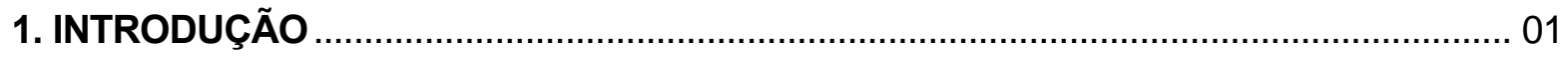

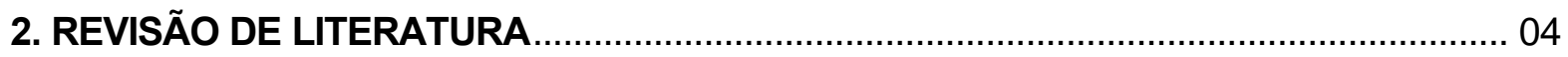

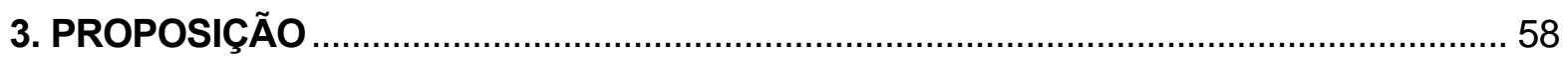

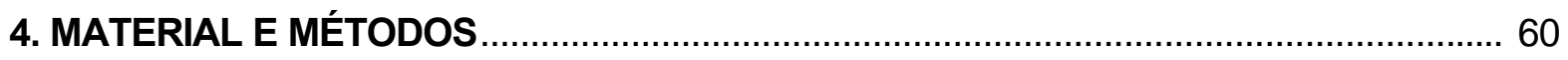

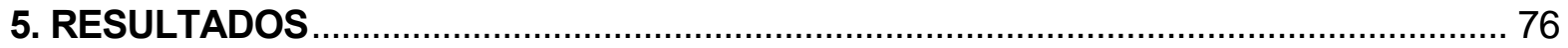

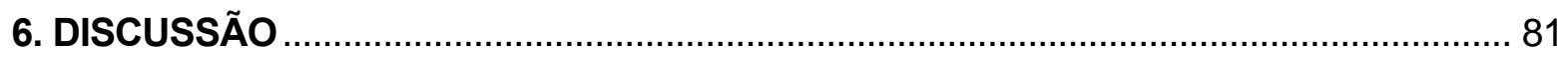

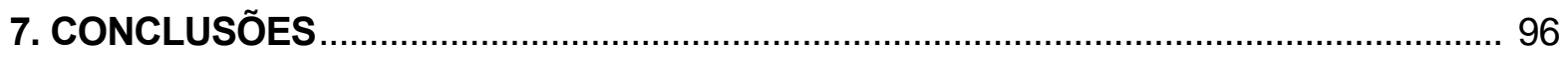

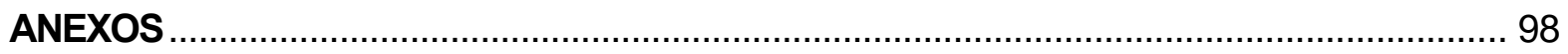

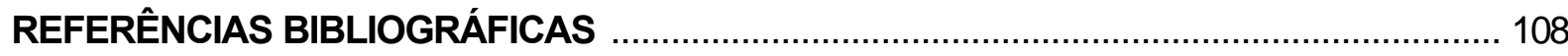

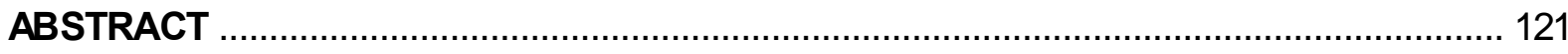




\section{LISTA DE ABREVIATURAS, SIGLAS E SÍMBOLOS}

$\%$

$\mu \mathrm{m}$

$\pm$

$\mathrm{mm} / \mathrm{min}$

ADA

Bis-GMA

CC

$\mathrm{cm}$

$\mathrm{cm}^{2}$

DMAEMA

DMPT

DP

9

HEMA

HR

in vitro (latim)

$\mathrm{Kg}$

$\min$.

$\mathrm{mm}$

$\mathrm{mm}^{2}$

$\mathrm{mW} / \mathrm{cm}^{2}$

$\mathrm{MPa}$

n..

$\mathrm{nm}$

$\stackrel{\circ}{C}$ porcentagem

micrometro

mais ou menos

milímetro por minuto

American Dental Association

bisfenol glicidil metacrilato

centímetro cúbico

centímetro

centímetro quadrado

dimetil-amino-etil metacrilato

dimetil-para-toluidina

desvio padrão

grama

2-hidroxi-etil metacrilato

número de dureza Rockwell

em laboratório

quilograma

minuto

milímetro

milímetro quadrado

miliwatts por centímetro quadrado

Mega pascal

número

nanômetro

grau Celsius 
probab.

seg.

TEGDMA/ TGDMA

UDMA/ UEDMA

$\mathrm{H}_{3} \mathrm{PO}_{4}$

$\mathrm{Al}_{2} \mathrm{O}_{3}$

$\mathrm{HF}$ probabilidade

segundos

trietileno glicol dimitacrilato

uretano dimetacrilato

ácido fosfórico

óxido de alumínio

ácido hidrofluoríd rico 


\section{RESUMO}

Este estudo teve como objetivo avaliar a adesão de reparos em resina composta utilizando-se o compósito Tetric Ceram, por meio de aplicação de forças de tração (micro-tração). Foram concebidos nove grupos sendo que no momento do reparo, cada grupo recebeu um tratamento de superfície específico: ácido fosfórico a 37\%, ácido fluorídrico a 10\% ou jateamento com partículas de óxido de alumínio de $50 \mu \mathrm{m}$. Tais tratamentos foram seguidos da aplicação de um agente adesivo (Heliobond) associado ou não a um agente silanizador (Monobond - S). Foram também confeccionados espécimes íntegros que não sofreram nenhum tipo de reparo e compunham o grupo controle. Os espécimes reparados e não reparados foram armazenados em água deionizada por 18 meses. Decorrido este período os corpos-de-prova foram levados a uma máquina de ensaios universal e realizados os testes de resistência à tração. Após análise dos resultados pôde-se verificar que os espécimes que não sofreram nenhum tipo de reparo (grupo controle) apresentaram resistência à tração estatisticamente superior em relação aos reparados independentemente do tratamento superficial empregado sobre os últimos. Observou-se ainda que o emprego do ácido fosfórico e posterior inserção do sistema adesivo, bem como a utilização do agente silanizador seguida da aplicação do sistema adesivo, apresentaram resultados estatisticamente semelhantes entre si e significantemente superiores em relação aos demais grupos reparados. O emprego do ácido hidrofluorídrico como agente condicionador resultou estatisticamente nos piores resultados de resistência à tração em relação aos demais tratamentos superficiais efetuados. 


\section{INTRODUÇÃO}




\section{INTRODUÇÃO}

Recentes avanços na área das restaurações estéticas têm contribuído para a utilização das resinas compostas como material restaurador não somente nos dentes anteriores, mas também em áreas de incidência de esforços oclusais. Porém as resinas compostas apresentam ainda limitações com relação a sua resistência ao desgaste diante das funções mastigatórias e a sua capacidade de manter uma união duradoura com a estrutura dentária. Além destes problemas, descoloração marginal, manchamentos, perda de contorno anatômico e pequenas fraturas têm sidos aspectos comumente encontrados nas restaurações de resinas compostas.

Invariavelmente quando realizamos a substituição de uma restauração tornamos maior as dimensões originais da cavidade preparada anteriormente, além de injuriarmos o complexo dentina-polpa ${ }^{46}$. Portanto o procedimento de reparo de uma restauração deve ser levado em consideração não somente pelos aspectos biológicos já salientados mas também em relação ao baixo custo que tal procedimento apresenta quando comparado à substituição tota ${ }^{44}$. Obviamente aspectos importantes devem nortear tal decisão como a presença ou não de lesão cariosa sob a restauração, a extensão do procedimento reparador, o padrão oclusal do elemento dentário envolvido e o risco em relação à cárie dentária apresentado pelo paciente ${ }^{62}$.

Porém apesar de todos os benefícios que o reparo de uma restauração de resina composta possa apresentar alguns questionamentos são feitos. Uma das grandes dúvidas é se após o emprego desta técnica teremos uma maior 
integridade e longevidade da restauração envolvida. Esta celeuma ocorre porque a superfície de uma restauração de resina composta fraturada é formada por uma matriz orgânica já polimerizada, sendo desta forma menos reativa, e por partículas de carga que muitas vezes podem estar sem a cobertura de silano, o que impede a formação de ligações químicas com a nova camada de resina composta ${ }^{83}$. Outro aspecto a ser salientado é que na maioria das vezes o profissional não tem conhecimento qual o tipo de resina composta foi empregado na confecção da restauração original. Este dado é importante, pois pode influenciar o aspecto estético da restauração devido à diferença de cor, textura e brilho das diversas marcas comerciais de resina composta, bem como a resistência final da restauração.

Diante de tais evidências uma série de estudos têm sido realizados no sentido de elucidar as dúvidas citadas bem como estabelecer um protocolo de execução de reparo de restaurações que envolvam resina composta, procurando estabelecer uma restauração reparada que apresente durabilidade, resistência, funcionalidade e estética.

Levando-se em consideração o uso cada vez mais contínuo e rotineiro da resina composta como material restaurador, das limitações conhecidas e apresentadas por este material e tendo em vista a validade da execução dos procedimentos de reparo o presente estudo tem por objetivo comparar, in vitro, a eficácia dos diferentes tratamentos superficiais de restaurações de resina composta que são passíveis de receberem tal procedimento reparador. 
2. REVISÃO DE LITERATURA 


\section{REVISÃO DE LITERATURA}

As resinas sintéticas são empregadas como materiais restauradores porque são insolúveis, estéticas, insensíveis a desidratação, de baixo custo e, relativamente, de fácil manipulação. Entretanto, logo após terem sido lançadas no final dos anos 40 e início dos anos 50, elas foram vistas com um certo ceticismo, uma vez que se enquadravam parcialmente no quesito estético, como material restaurador de dentes anteriores, no que se referia à sua durabilidade estética. Algumas características, tais como a similitude na coloração de dentes naturais e a insolubilidade aos fluidos bucais, as fizeram superiores aos cimentos de silicato, entretanto, sua alta contração de polimerização e seu alto coeficiente de expansão térmica as levavam a deficiências clínicas e fracassos prematuros. Assim, devido às contínuas deficiências apresentadas pelas resinas acrílicas, surgiram vários estudos a fim de que um material adesivo estético, de inserção direta, fosse desenvolvido e que este pudesse ser utilizado rotineiramente com segurança ${ }^{6}$.

$\mathrm{Na}$ década de 60, BOWEN ${ }^{12}$ desenvolveu a chamada "Resina de Bowen" ou Bis-GMA a partir de uma combinação entre a resina epóxica e a resina de metacrilato, unindo suas boas propriedades através da reação química entre bisfenol A e glicidil metacrilato. Bowen procurou extrair da resina epóxica, a baixa alteração dimensional e da resina de metacrilato, a rápida velocidade de polimerização.

A "Resina de Bowen", precursora das resinas compostas atuais, ainda possuía propriedades físicas deficientes, como baixa resistência ao desgaste e alta contração de polimerização. Em 1963, procurando aprimorar as propriedades físicas do material anteriormente citado, BOWEN ${ }^{13}$, desenvolveu um método de 
incorporação de partículas inorgânicas à matriz de polímero orgânico. O método utilizado por BOWEN ${ }^{13}$, baseava-se na cobertura da partícula de sílica com um agente anfótero vinil silano. Este agente promovia a adesão entre a fase orgânica e inorgânica da resina composta. O método de incorporação de partículas inorgânicas á matriz orgânica da reina de Bowen resultou em redução da contração de polimerização, redução do coeficiente de expansão térmica e aumento da resistência à compressão, módulo de elasticidade e resistência à edentação da resina composta quando comparada às resinas sem reforço de carga. Este novo material apresentou também baixas solubilidade e desintegração em água e maior resistência à tração que o cimento de silicato. A incorporação de partículas inorgânicas à fase orgânica da resina sem o tratamento superficial prévio com vinil silano, revelou propriedades inferiores depois de equivalente período de imersão em água.

As propriedades das resinas compostas foram amplamente discutidas em 1969, por PHILLIPS; SWARTZ; NORMAN ${ }^{70}$. Apontaram como vantagens dos compósitos, quando comparados às resinas acrílicas, a alta resistência à compressão e à abrasão, dureza superior, contração de polimerização e coeficiente de expansão térmica menores e maior facilidade de manipulação.

Em 1971, FORSTEN; VÄLIAHO ${ }^{38}$, realizaram um estudo comparativo avaliando a resistência ao cisalhamento de vários materiais restauradores entre eles, o cimento de silicato, a resina acrílica e sete resinas compostas. No mesmo estudo procuraram determinar a resistência de reparos realizados em resina acrílica e em resina composta, para isto os corpos-de-prova foram envelhecidos em água durante 6 a 12 semanas. Findado este tempo os espécimes foram abrasionados e posteriormente acoplados a uma matriz metálica para serem reparados. Quanto à 
resistência ao cisalhamento o cimento de silicato foi aquele que apresentou médias mais baixas e a resina composta foi o material que apresentou médias mais altas. A resina composta apresentou médias de resistência de até cinco vezes a resistência do cimento de silicato e duas vezes a da resina acrílica. Em relação aos reparos, tanto aqueles realizados em resina acrílica quanto em resina composta, exibiram médias de resistência menores quando comparados à espécimes não reparados do mesmo material, isto é, comparados à resistência coesiva do material. Os autores recomendaram ainda a necessidade de confecção de retenções mecânicas quando da realização de reparos em restaurações que envolvessem os materiais estéticos estudados.

Em 1971, REISBICK; BRODSKY ${ }^{74}$, testaram laboratorialmente a resistência de união entre resinas compostas reparadas ou não, polimerizadas sobre base de óxido de zinco e eugenol ou sobre uma placa de vidro. Os materiais utilizados foram quatro resinas com carga e como controle foi utilizada uma resina sem carga. Dez meio-espécimes de cada material foram confeccionados e reparados após 10 minutos ou após 24 horas de armazenamento em água. Após o reparo, as amostras foram armazenadas em água durante 7 dias e então submetidas ao teste de resistência transversa. Todos os materiais apresentaram redução na resistência depois de reparados, sendo esta redução significante tanto para o período de 10 minutos quanto para o de 24 horas. O estudo indicou ainda, que algumas resinas compostas sofrem uma redução significante na resistência flexural quando polimerizadas sobre bases de óxido de zinco e eugenol. Os autores sugeriram que a significância clínica dos dados obtidos ainda não era conhecida.

Em 1975 foi avaliada por CAUSTON ${ }^{20}$ a resistência ao cisalhamento de 
reparos realizados com diferentes resinas compostas. Neste estudo foram utilizados materiais que apresentavam diferentes viscosidades e características de polimerização. A importância de fatores como o conteúdo de água na resina envelhecida e o efeito da idade sobre a resistência adesiva dos reparos também foram analisados. Os resultados foram significantemente diferentes para cada material testado, assim como para resinas maturadas em água e a seco. Dos espécimes armazenados em água, somente uma das resinas compostas testadas demonstrou aumento da resistência após um período de 1 a 8 semanas, o que foi atribuído à baixa adsorsão de água do material, comparado com os outros compósitos utilizados no estudo, e à contínua polimerização da resina durante o período de 2 meses. As resinas menos viscosas forneceram valores maiores de resistência, quando comparadas às mais viscosas. Os resultados indicaram que as ligações formadas entre uma resina maturada e uma resina recém polimerizada foram duráveis em meio aquoso e adequadas clinicamente, desde que fossem evitadas camadas muito finas de material, e que a superfície fosse limpa e seca antes da aplicação do novo compósito.

BOWEN; REED ${ }^{14}$, em 1976, tentando ainda o aperfeiçoamento das propriedades físicas das resinas compostas realizaram um trabalho com objetivo de determinar quais das composições já conhecidas de resina composta seria capaz de formar duas fases contínuas interligadas com dimensões tão pequenas que não permitissem a visualização de dispersão de luz. Foram utilizadas partículas experimentais de carga que foram preparadas a partir do tratamento térmico de algumas composições vítreas, seguidas de trituração e condicionamento com ácido clorídrico a $3 N(10,4 \%)$ e ácido fosfórico a $3 N(9,3 \%)$. Através de microscópio óptico 
foram observadas zonas porosas se desenvolvendo internamente nas partículas de vidro após o condicionamento. Os autores concluíram que é possível desenvolver partículas vítreas em duas fases distintas e interligadas. Cada uma das fases foi dissolvida com o emprego de soluções ácidas fortes, resultando em uma zona porosa na superfície. Segundo os autores, esta superfície resultante, composta de um certo conteúdo de sílica, poderia receber um tratamento químico com um promotor de adesão silano e, consequentemente, aumentar a adesão entre as partículas de carga e a matriz resinosa pela interpenetração das fases orgânica e inorgânica da resina composta.

Em 1977, CARNEIRO et al. ${ }^{19}$, realizaram um trabalho em laboratório para verificar comparativamente a influência de reparos em amostras de resina composta, com e sem a aplicação de selante ou líquido catalisador, sobre resistências à tração dos corpos-de-prova. O controle foi representado por espécimes inteiros, isto é, não reparados. Para cada um dos dois materiais testados foram confeccionadas 120 amostras sem reparo, as quais foram armazenadas em água ou a seco durante $1 \mathrm{e}$ 24 horas, e amostras com reparo, com e sem aplicação de selante ou catalisador, armazenadas sob as mesmas condições dos corpos-de-prova não reparados. Decorridos os períodos de armazenamento, os espécimes foram submetidos ao teste resistência à tração em um aparelho especialmente desenvolvido para o estudo. Os autores observaram que a resistência à tração dos espécimes reparados foi menor que a dos não reparados. Quando um agente de união ou catalisador foi utilizado a resistência à tração dos corpos-de-prova reparados foi maior, comparada aos espécimes reparados sem aplicação prévia desses materiais, para qualquer um dos materiais testados. As amostras submetidas ao teste de tração após o período 
de armazenamento de 24 horas mostraram-se mais resistentes que aquelas testadas após 1 hora de armazenamento.

No fim dos anos 70 uma nova técnica restauradora foi sugerida para confecção de restaurações de Classe II de resina composta devido à dificuldade de adaptação na parede cervical. Esta técnica preconizava a inserção da resina no preparo em incrementos, sendo um proximal e outro oclusal. Esta nova forma de aplicação da resina composta apesar do objetivo de facilitar a acomodação do material restaurador na região cervical da cavidade originou uma restauração com "emenda". Visando verificar a efetividade desta técnica, CONSANI; STOLF; RUHNKE ${ }^{26}$, em 1977, mediram a resistência à tração de emendas em resinas compostas, assim como o aspecto fotomicrográfico e auto-radiográfico das zonas emendadas. Para tanto, foram confeccionados espécimes inteiros para cada resina composta quimicamente ativada empregada no estudo. Os espécimes emendados foram obtidos preenchendo somente metade da matriz e, após 15 minutos, reparados com outra porção de material. Cada grupo foi subdividido de acordo com o tempo de armazenamento em água destilada a $37^{\circ} \mathrm{C}$, ou seja, 15 minutos, 1 hora e 24 horas. A análise dos valores obtidos demonstrou que a resistência à tração, tanto dos espécimes inteiros quanto dos emendados, aumentou proporcionalmente ao tempo de armazenamento. Entretanto, a resistência dos espécimes sem emenda foi significantemente maior que a apresentada pelos espécimes com emenda. Apesar de menos resistentes, os espécimes emendados não apresentaram sinais de penetração do marcador na interface, segundo o teste auto-radiográfico. Do mesmo modo, as fotomicrografias das zonas de reparo não evidenciaram nenhum vestígio de solução de continuidade na interface. Os autores sugeriram que houve uma união 
química entre os incrementos de resina composta, porém, em uma condição diversa da normal, comprometendo o fator físico de resistência à tração.

Em 1978, BOYER; CHAN; TORNEY ${ }^{16}$, também desenvolveram um trabalho laboratorial para estudarem restaurações de resina confeccionadas por incrementos. Este estudo também teve como objetivos determinar o efeito do preparo da superfície e investigar métodos que levassem ao aperfeiçoamento da adesão às superfícies de resina composta. Amostras completas foram usadas como controles e testadas 24 horas após sua confecção. As amostras experimentais para reparo foram polimerizadas contra uma matriz plástica ou expostas ao ar. A segunda porção de compósito foi adicionada após períodos de tempo determinados. Os resultados foram analisados e demonstraram que a resistência dos espécimes polimerizados contra a matriz plástica foi semelhante à resistência coesiva do material, quando o reparo foi realizado após 7 e 30 minutos. Para os espécimes polimerizados expostos ao ar, quando a adição de resina foi feita após 30 minutos ou 24 horas, os valores de resistência foram inferiores ao controle. Quando um agente de união foi aplicado às superfícies desgastadas com brocas, houve um aumento considerável na resistência dos reparos. Os autores concluíram que superfícies de resina composta polimerizadas expostas ao ar ou em contato com uma matriz plástica foram excelentes substratos para adesão de nova resina quando a inserção desta era realizada até 30 minutos após a polimerização da última porção do material. Mas, nos casos de reparos, isto é, a inserção de novas camadas de resina sobre uma restauração realizada a mais de 30 minutos, a aplicação de uma fina camada de agente de união pode proporcionar maior resistência adesiva.

RUYTER; SVENDSEN ${ }^{77}$, em 1978, determinaram a quantidade de grupos 
metacrilato não reagidos remanescentes em resinas compostas polimerizadas, através de espectroscopia de reflexão interna múltipla. As medidas foram realizadas antes e depois da polimerização, repetidas vezes a $37^{\circ} \mathrm{C}$, durante 24 horas. A quantidade encontrada de grupamentos metacrilato remanescentes para as seis resinas utilizadas variou de $25 \%$ a $48 \%$ depois de 24 horas, o que demonstrou uma diferença no grau de conversão entre os materiais depois da polimerização. Segundo os autores estas diferenças poderiam estar relacionadas às diferentes formulações químicas dos materiais testados.

Em 1980, LLOYD; BAGRIE; JEFFREY ${ }^{77}$, buscaram determinar a resistência à tração de corpos-de-prova reparados confeccionados com diferentes resinas compostas. Cinco resinas com diferentes características químicas foram selecionadas para o estudo. Os corpos-de-prova foram divididos em grupos controle (sem reparo) e reparados. As amostras reparadas foram conseguidas de três diferentes formas: a primeira, o reparo foi realizado imediatamente após a confecção do corpo-de-prova não reparado; a segunda, o reparo foi realizado após contaminação da superfície a ser reparada por saliva; e por fim, foram confeccionados reparos em espécimes armazenados em água durante 7 (sete) dias (com e sem abrasionamento da superfície). A análise dos resultados demonstrou que não houve diferença entre a resistência coesiva (resistência dos espécimes inteiros) e a resistência adesiva dos reparos realizados imediatamente após a polimerização dos compósitos. Os reparos realizados nas amostras envelhecidas em água e nas contaminadas com saliva apresentaram valores de resistência significantemente menores que os reparos imediatos. Não houve diferença na resistência dos reparos realizados em compósitos maturados abrasionados ou não. 
YAFFE; ZALKIND ${ }^{96}$ em 1981, descreveram o efeito de uma solução de flúor acidulado sobre restaurações de resinas compostas, através de observação em microscópio eletrônico de varredura. Foram utilizados 160 dentes humanos extraídos. Foram confeccionadas cavidades de Classe $\mathrm{V}$ em todos os dentes e, então, os mesmos foram divididos em quatro grupos. Cada grupo restaurado com uma resina diferente. Após a restauração, os dentes foram imersos em uma solução de fluoreto de sódio a $2 \%$ durante 10 minutos e os controles foram imersos em solução salina pelo mesmo tempo. Em seguida, os espécimes foram preparados e observados em microscópio eletrônico de varredura. As superfícies das restaurações em resina composta submetidas à imersão em solução fluoretada demonstraram um aumento na rugosidade, quando comparadas aos controles, com exceção da resina convencional. Estes resultados foram justificados pela ação do ácido fluorídrico, que promoveu uma dissolução das partículas, resultando em superfícies mais rugosas.

Em 1982, VANKERCKHOVEN et al. ${ }^{92}$, avaliaram a influência de alguns fatores manipulativos sobre a concentração de grupamentos metacrilatos na superfície de resinas compostas através de espectroscopia de reflexão interna múltipla por infravermelho. O estudo tinha também o objetivo de investigar uma possível correlação entre os resultados de testes mecânicos e o grau de insaturação química dos materiais. Como parte da investigação química, a porcentagem de duplas ligações foi medida 30 minutos, 5 e 24 horas após o início da polimerização. Para a análise da influência da temperatura, os espécimes de 3 diferentes resinas foram armazenados a $37^{\circ} \mathrm{C}$ durante 15 dias e $55^{\circ} \mathrm{C}$ durante 21 dias, medindo-se a quantidade de duplas ligações antes e depois desses períodos. A interferência do polimento da superfície também foi investigada com relação à quantidade de duplas 
ligações, por meio de teste de resistência à flexão. Os resultados indicaram que a quantidade de duplas ligações atingiram constância muito rapidamente. A temperatura produziu uma ligeira queda na porcentagem de duplas ligações para todos os materiais após 2 semanas a $37^{\circ} \mathrm{C}$, enquanto o aumento da temperatura para $55^{\circ} \mathrm{C}$ não exerceu nenhuma mudança significante. Após o polimento, houve uma diminuição significante na quantidade de radicais livres, representada por reduções de $1 / 3$ a $3 / 4$ na resistência dos reparos, quando comparados aos espécimes inteiros. Os autores sugeriram que quanto maior a quantidade de monômeros Bis-GMA, maior a quantidade de duplas ligações remanescentes. Concluíram que as superfícies de resina formadas contra uma matriz plástica produzem uma adesão interfacial correspondente à metade da resistência coesiva do material.

Em 1982, INOUE; HAYASHII ${ }^{48}$ realizaram um estudo onde buscou-se desenvolver um método para medir a quantidade de monômero residual de várias resinas compostas e determinar a porcentagem de monômero liberado com o armazenamento em água. Espécimes esféricos foram confeccionados com cada material e pesados após a polimerização. Em seguida, as amostras foram armazenadas em água a $37^{\circ} \mathrm{C}$ durante 3,7 e 13 dias e pesados novamente. Com o auxílio de um cromatógrafo, três determinações foram executadas para cada solução. Monômeros residuais Bis-GMA foram encontrados em todos os compósitos testados. A porcentagem de monômeros residuais medida logo após à polimerização variou de $0,4 \%$ a $1,21 \%$ do peso original das resinas compostas polimerizadas. Quando os materiais foram imersos em água durante 13 dias, a quantidade de monômero residual dissolvido foi reduzida a aproximadamente $1 / 10$ da quantidade 
de monômeros detectada imediatamente depois da polimerização.

MURREY et al. ${ }^{66}$, também em 1982, realizaram uma investigação para determinar a influência do desgaste da superfície de restaurações antigas antes de uma nova camada de material ser aplicada sobre a resistência adesiva dos reparos. As amostras de resina não reparadas foram armazenadas em saliva artificial a $37^{\circ} \mathrm{C}$ durante 60 dias. Os desgastes foram feitos com broca esférica ou ponta diamantada sobre a superfície a ser reparada. Em metade dos espécimes foi aplicado um sistema adesivo e os reparos foram realizados com a mesma resina do corpo-deprova original. Os autores concluíram que quando nenhum tratamento de superfície foi empregado, os valores de resistência adesiva foram inferiores aos do grupo controle e dos grupos que receberam algum tratamento de superfície. Deste modo, foi sugerido que os reparos em resinas compostas envelhecidas fossem precedidos de um desgaste superficial visando aumentar a resistência de união.

KULA; NELSON; THOMPSON ${ }^{50}$, em 1983, realizaram um estudo laboratorial na tentativa de determinar os efeitos do gel de flúor fosfato acidulado a $1,23 \%$ sobre três resinas comerciais.. As resinas estudas possuíam diferentes porcentagem, tipo e tamanho de partículas de carga. Pequenas pastilhas de resina foram confeccionadas, polidas com lixa de granulação 600 e imersas em água. Dez amostras de cada resina foram pesadas e imersas em um gel de flúor acidulado a $1,23 \%$ por $4 \mathrm{~mm}$. Após lavados e limpos com ultra-som, os espécimes foram repesados. Repetiu-se o processo 5 vezes. As amostras controle foram submetidas ao mesmo tratamento, porém foram imersas em água destilada e não flúor. Os resultados obtidos demonstraram uma perda de peso significantemente maior para todas as resinas imersas em flúor, quando comparadas com seus controles. As 
resinas com partículas de vidro de estrôncio foram as mais afetadas pelo flúor, seguidas das partículas de quartzo e de sílica. Ao microscópio eletrônico pode-se perceber alterações mínimas nas resinas com partículas de sílica e moderadas nas de quartzo. As amostras de resina com partículas de vidro de estrôncio apresentaram alterações superficiais extensas.

Em 1983, CHAN; BOYER ${ }^{23}$ estudaram a resistência de união entre várias resinas incluindo convencionais, microparticuladas e híbridas. Os espécimes foram fabricados com moldes divididos de teflon e preparados para reparo seccionando-os ao meio com broca de fissura. Em seguida, as amostras retornaram aos moldes e receberam as resinas de reparo. Após períodos de armazenamento de 15, 30 e 60 minutos, 24 horas ou 7 dias em água a $37^{\circ} \mathrm{C}$, os espécimes foram testados quanto à resistência à tração. Os resultados demonstraram que os reparos com resinas convencionais produziram valores correspondentes a $67,6 \%$ da resistência coesiva do material, enquanto que para as resinas de micropartículas os valores foram de $76,4 \%$. O tempo influenciou os resultados para a resina convencional, pois os espécimes foram mais resistentes em 7 dias, quando comparados com os de 15 ou 30 minutos e 1 hora. Uma das resinas compostas se comportou melhor que os outros materiais, o que foi justificado pela sua alta concentração de monômeros monofuncionais, os quais possuem menor viscosidade e, portanto, exercem maior penetração na superfície do substrato. As resinas de micropartículas se mostraram bons adesivos para as resinas convencionais, quando as matrizes resinosas eram de mesmo tipo, e também resultou em boa adesão em reparos com o mesmo material. Porém, observaram que resinas de natureza química diferentes não conseguem adesão adequada, assim, a resina de micropartículas a base de UDMA 
(uretano dimetacrilato) não foi capaz de produzir adesão satisfatória com as resinas de Bis-GMA.

Procurando avaliar a infiltração marginal em restaurações que sofreram reparo, MEEKER, HIRSCH; KAIM ${ }^{61}$, em 1983, preparam cem cavidades de classe $\mathrm{V}$ em dentes humanos extraídos, e dividiram os mesmos em 3 grupos de acordo com o método de reparo. Um dos grupos foi condicionado com ácido seguida da aplicação de um agente adesivo, o outro grupo foi condicionado porém, não ocorrendo a aplicação do adesivo. O último grupo, por sua vez, não recebeu nenhum tipo de tratamento. Todos os espécimes foram termociclados 100 vezes em banhos de $10^{\circ} \mathrm{C}$ e $40^{\circ} \mathrm{C}$, e imersos em fucsina básica a $0,5 \%$ durante 96 horas, a fim de localizar falhas na margem das restaurações em resina composta, por meio da penetração do corante na interface reparada. Após o seccionamento dos espécimes, a avaliação da infiltração, penetração do corante, foi realizada por meio de escores. A comparação entre os grupos revelou menores índices de infiltração marginal no grupo de condicionamento ácido e adesivo, enquanto o grupo que não recebeu nenhum tratamento demonstrou os maiores índices de infiltração. Mesmo assim não foi detectada diferença estatisticamente significante entre os grupos, demonstrando que uma resina composta pode ser adicionada a outra para corrigir defeitos sem a necessidade de condicionamento com ácido e aplicação de um agente de união, desde que a contaminação da superfície seja evitada.

MIRANDA et al. ${ }^{63}$, em 1984, desenvolveram um trabalho laboratorial para determinar o melhor tratamento superficial para realização de reparos em resinas compostas convencionais e de micropartículas. Para tal foram confeccionados corpos-de-prova cilíndricos, que depois de ficarem armazenados em água por uma 
semana, foram reparados. Dez espécimes inteiros foram confeccionados com as mesmas características geométricas dos demais e armazenados (controle). Para realização dos reparos os corpos-de-prova tiveram suas extremidades polidas com lixa granulação 220 e foram divididos em três grupos de acordo com o tratamento: ácido fosfórico a 37\% por 1 minuto com e sem aplicação de uma resina fluida e o terceiro grupo não recebeu nenhum tipo de tratamento adicional. Os reparos foram realizados com combinações entre as resinas testadas, convencional ou micropartículas. Os espécimes foram então testados quanto sua resistência flexural, uma semana após o reparo ser confeccionado. A resistência dos corpos-de-prova inteiros, resistência coesiva, foi significantemente maior que a resistência dos espécimes reparados. A resistência adesiva, corpos-de-prova reparados, variou de $32 \%$ a $66 \%$ para a resina convencional e $48 \%$ a $78 \%$ para a de micropartículas comparando-se à resistência coesiva de cada material. De um modo geral, os reparos realizados nos espécimes de resina convencional foram mais resistentes que os realizados em resina de micropartículas. $O$ tratamento que proporcionou maior resistência interfacial aos corpos-de-prova reparados foi o polimento, seguido de ácido fosfórico e agente de união, independentemente do tipo de resina envolvida no reparo.

FORSTEN ${ }^{37}$, em 1984, apresentou um estudo para testar a força de união de espécimes confeccionados a partir da aplicação de nova resina após a polimerização da resina composta de parte do corpo-de-prova. Utilizando um molde especial foram confeccionados espécimes de formato retangular. Um grupo controle foi constituído de espécimes inteiros de resina. Para confecção dos grupos experimentais o terço médio do molde era preenchido com uma barra plástica e o 
espaço resultante recebia a inserção de resina que por sua vez era fotoativada, promovendo a polimerização. Após a remoção do espaçador, o mesmo material era acomodado e fotopolimerizado. Para um dos grupos experimentais, previamente à aplicação da resina composta, o local deixado pelo espaçador era preenchido com água destilada pelo tempo de 1 minuto. Realizava-se esta etapa para simular a contaminação dos corpos-de-prova. A totalidade das amostras foram armazenadas em água a $22^{\circ} \mathrm{C}$ durante 24 horas e submetidas ao teste de resistência transversa de três pontos. Os resultados obtidos demonstraram não haver diferença estatisticamente significante na resistência entre os espécimes inteiros e os incrementais, e ainda que a contaminação com água não reduziu a resistência transversa das amostras de maneira considerável. Comparando-se, as resinas de macropartículas e as microparticuladas, as primeiras apresentaram um melhor desempenho geral com relação às últimas.

Em 1984, BOYER; CHAN; REJNHARDT ${ }^{15}$, avaliaram a resistência de união de corpos-de-prova de resina confeccionados em dois tempos, sendo que uma das partes era confeccionada decorrido determinado tempo da polimerização da primeira porção. Desta maneira os novos incrementos de resina eram inseridos de 2 a 20 minutos após a polimerização da porção inicial e ainda, para simular o reparo dos corpos-de-prova novas adições de material eram realizadas com 24 horas e após 7 dias da confecção da amostra. Foram testadas resinas densamente carregadas (75 a 77\% de carga) e de micropartículas (37 a 66\% de carga), sendo oito ativadas fisicamente e três ativadas quimicamente. Espécimes inteiros de resina (controle) foram confeccionados, armazenados em água a $37^{\circ} \mathrm{C}$ durante 24 horas e submetidos a teste de resistência transversa. Para os grupos experimentais, que 
simulavam o reparo de restaurações, foram utilizados alguns tratamentos de superfície previamente à aplicação da nova camada de resina. Em um dos grupos nenhum tratamento foi realizado, em outros as superfícies a serem reparadas foram submetidas à ação de um disco abrasivo e receberam, ou não, a aplicação de agente de união. Os resultados demonstraram que a resistência transversa foi superior às médias de resistência adesiva interfacial em qualquer tempo experimental. Durante os primeiros dez minutos houve um aumento significante na dureza, seguido de um aumento gradual da mesma propriedade até 24 horas. Quanto aos reparos, a resistência adesiva das resinas de micropartículas foi maior com a presença do agente de união, obtendo valores semelhantes a resistência coesiva dos materiais. Os reparos em resinas envelhecidas por 7 dias apresentaram resistência significantemente menor, para todos os grupos experimentais, que a força coesiva dos materiais.

Em 1985, LLOYD; DHURU ${ }^{58}$ mediram a energia de fratura (fracture toughness) na interface de espécimes de resina composta de macropartículas reparados imediatamente ou após 1 hora de armazenamento em saliva artificial. A adição de material foi realizada diretamente sobre a superfície ou precedida da aplicação de uma camada de agente de união. Quando comparada aos valores de resistência coesiva do material, a energia de fratura dos espécimes reparados foi significantemente menor. Nos espécimes contaminados por saliva antes do reparo houve uma redução significante na resistência devido à inibição da formação de ligações químicas entre as duas superfícies, porém o emprego do agente de união foi capaz de aumentar a energia de fratura, de modo a torná-la semelhante a dos reparos executados sobre superfícies sem contaminação. 
PODSHADLEY; GULLET; BINKLEY ${ }^{11}$, no mesmo ano, realizaram um trabalho com objetivo de comparar a resistência adesiva entre espécimes de resina composta confeccionados pela técnica do incremento único e espécimes confeccionados a partir da aplicação de novas camadas de material a uma superfície de resina previamente fotopolimerizada. As condições experimentais foram elaboradas de modo a simular a técnica de inserção incremental de compósitos fotopolimerizáveis. Os corpos-de-prova foram confeccionados com resinas de partículas pequenas, micropartículas e híbridas. Todas as amostras foram armazenadas em água a $37^{\circ} \mathrm{C}$ durante 24 horas antes de serem submetidas ao teste de resistência à tração. Os resultados indicaram que apenas as amostras adicionadas de resinas de partículas pequenas se mostraram menos resistentes que suas respectivas amostras inteiras. Contrariamente os espécimes confeccionados com uma das resinas de micropartículas resultaram-se mais resistentes que os espécimes inteiros do mesmo material. Os autores não detectaram diferença de resistência entre amostras inteiras e confeccionadas pela técnica incremental para os outros compósitos testados. Os autores concluíram que a técnica de inserção incremental pode ser executada com sucesso.

Em 1985, DHURU; LLOYD ${ }^{32}$ mediram a resistência interfacial de reparos em resina composta por meio de teste de "energia de fratura". Foram confeccionadas amostras controle, as quais foram fraturadas depois de 24 horas. As mesmas amostras foram utilizadas para a confecção dos espécimes reparados. As superfícies a serem reparadas foram submetidas ou não à contaminação com saliva artificial e o reparo foi realizado com o material original da amostra inicial ou com outro tipo de resina. Foram observadas reduções significantes na resistência 
entre todos os grupos de reparos e os respectivos controle, sendo que o efeito da contaminação salivar foi altamente significante, diminuindo a resistência dos reparos em todos os casos. Os reparos realizados com material diferente do original demonstraram valores de resistência inferiores àqueles reparos onde foi utilizado o mesmo compósito. Quando os resultados foram transformados em porcentagens relativas aos grupos controle, os índices variaram de $45 \%$ a $88 \%$ da resistência coesiva dos materiais testados. Os autores concluíram que, reparos efetivos podem ser realizados em resinas compostas maturadas. Apesar da energia de fratura ter sido significantemente menor que a força coesiva dos materiais, os valores obtidos foram considerados altos.

Em 1985, SÖDERHOLM et al. ${ }^{86}$ investigaram a liberação de componentes das partículas inorgânicas de quatro diferentes compósitos armazenados em água. As concentrações de silício, estrôncio e bário dissolvidas na água foram determinadas por meio de espectrofotometria de absorção atômica. Amostras adicionais não armazenadas e amostras armazenadas durante 180 dias foram obtidas para observações em microscópio eletrônico de varredura e em espectrofotômetro Os resultados encontrados confirmaram achados de estudos anteriores onde a dissolução de íons silício de diferentes compósitos foi altamente dependente da composição inorgânica dos materiais. Com relação à superfície total de cada resina composta, aquelas que continham partículas de quartzo e sílica pirolítica liberaram menor quantidade de silício, quando comparadas às compostas de vidros de estrôncio e/ou bário. Houve uma correlação entre dissolução de íons e formação de trincas em todos os materiais, exceto na resina de micropartículas. 0 aparecimento das trincas foi atribuído à formação de pressão osmótica em espaços 
vazios no interior do compósito, provenientes da degradação hidrolítica. Pôde-se concluir que a resina de micropartículas foi a mais estável sob armazenamento em água, com relação à formação de trincas.

AZARBAL; BOYER; CHAN $^{9}$, em 1986, investigaram a interferência de vários agentes de união e resinas compostas, bem como a utilização de solventes, como clorofórmio e acetona, além de um primer silano, nas situações de reparo de restaurações. Um grupo controle, que consistia de espécimes inteiros, foi confeccionado para fazer a medida da resistência coesiva de cada material. Para obtenção dos grupos experimentais foram confeccionados inicialmente sob um molde especial, amostras ainda não reparadas que foram armazenadas, trinta minutos após sua remoção do molde, em água destilada a $37^{\circ} \mathrm{C}$ durante 7 dias. $\mathrm{O}$ reparo foi então realizado e cada grupo recebeu tratamento específico com agentes de união ou solventes. Outro grupo foi composto de espécimes reparados sem tratamento de superfície prévio. Após a confecção dos reparos, os espécimes foram novamente armazenados em água destilada a $37^{\circ} \mathrm{C}$ durante 24 horas. Decorrido este tempo os corpos-de-prova foram submetidos ao teste de resistência flexural de três pontos. De um modo geral, a resistência dos reparos foi menor que a resistência coesiva dos espécimes não reparados. O agente de união conferiu os maiores valores de resistência aos reparos, com todos os materiais utilizados. Já o agente silanizador não foi efetivo na promoção de adesão entre os compósitos neste estudo. Dentre as resinas, as de micropartículas produziram os valores mais altos de resistência nos reparos, quando comparadas as de macropartículas. Este fato foi relacionado ao grande conteúdo de matriz resinosa das resinas de micropartículas.

Para avaliar a resistência de resinas compostas aplicadas e polimerizadas 
em incrementos, ELI et al..$^{33}$, em 1986, desenvolveu um estudo laboratorial utilizando 4 diferentes compósitos fotopolimerizáveis. Espécimes de cada material foram confeccionados e divididos em grupos de espécimes inteiros (inserção única) e em grupos onde a resina foi inserida e polimerizada em dois incrementos, com e sem a interposição de agente de união. Testes de resistência à tração foram realizados em todas as amostras. Os resultados demonstraram que o uso de agente de união aumentou, de um modo geral, a prevalência de fraturas fora da área adesiva. A resina sem carga empregada como adesivo entre as camadas polimerizadas de compósito promoveu uma redução de 6 vezes na incidência de fraturas na interface adesiva. Os autores indicam a aplicação de agente de união entre incrementos de resina composta para melhorar a qualidade final de restaurações profundas, ou quando houver necessidade de reparo de defeitos em restaurações já polidas.

KULA et al. ${ }^{51}$, em 1986, realizou um estudo procurando determinar, por meio de inspeção visual e por microscopia eletrônica de varredura, a degradação de superfície de resinas compostas provocada por um gel de flúor fosfato acidulado a 1,23\%. As resinas estudadas possuíam diferentes conteúdos de carga inorgânica e diferentes padrões de polimerização (química ou fisicamente ativadas). Para realização do estudo foram confeccionados discos de resinas dos diferentes materiais, e estes foram polidos depois de 24 horas. Duas amostras de cada resina foram imersas no gel de flúor durante 4 minutos, por 5 vezes. O mesmo procedimento foi realizado para os controles, porém com imersão em água. Os espécimes foram observados em microscópio eletrônico de varredura e de luz polarizada. Os espécimes com maiores alterações visuais demonstraram extensa degradação das partículas expostas ao flúor. O padrão de condicionamento variou 
de acordo com o tamanho e tipo de partícula, ou seja, partículas menores degradaram mais facilmente. Foram observadas porosidades nas resinas com partículas de sílica de $0,04 \mathrm{pm}$, enquanto nas resinas com partículas maiores foram notadas perda parcial e degradação superficial moderada. Neste estudo, os compósitos com partículas de vidro de boroaluminosilicato de bário foram os mais suscetíveis à degradação pelo gel de flúor fosfato acidulado a 1,23\%.

CHALKLEY; CHAN $^{22}$, ainda em 1986, observaram a capacidade de adesão de diferentes resinas compostas a outra resina envelhecida por 1 semana por meio de teste de microinfiltração. O estudo incluiu a determinação da viabilidade de reparos realizados com material diferente do original. Os tratamentos realizados nos espécimes iniciais foram a contaminação com saliva durante 1 segundo e condicionamento ácido, seguido ou não da aplicação de agente de união. Realizado o teste de penetração de corante, a análise dos resultados demonstrou que a contaminação salivar aumentou significantemente a infiltração na interface. $O$ tratamento com ácido fosfórico seguido de adesivo revelou os menores índices de penetração de corante, assim como reparos entre resinas de mesma composição resultaram em melhor adaptação, quando comparados com reparos entre materiais diferentes.

SÖDERHOLM ${ }^{84}$, em 1986, realizou um estudo para determinar diferenças na resistência flexural de espécimes de resina composta com e sem reparo. Neste estudo foram utilizados diferentes tratamentos de superfície antes da aplicação da resina de reparo. Entre outros tratamentos, foi utilizada uma solução de toluenosilano anteriormente à confecção do reparo. As amostras foram armazenadas em água destilada a $37^{\circ} \mathrm{C}$ durante 3 e 6 meses antes de serem submetidas aos testes 
de resistência flexural de quatro pontos. Os resultados demonstraram que os corposde-prova inteiros foram, de maneira geral, mais resistentes que aqueles com reparo. O grupo de amostras tratadas com silano apresentou resistência superior aos demais grupos, além de ter sido o menos afetado pela exposição à água, de modo a não exibir diferenças significantes com relação ao grupo não reparado (controle), mesmo após 6 meses de armazenamento. As observações ao microscópio eletrônico de varredura indicaram a presença de trincas na matriz resinosa e partículas de carga totalmente expostas nos espécimes onde foi utilizado o silano. Ao contrário, as superfícies tratadas com água e com ácido fosfórico se apresentaram cobertas por uma película orgânica proveniente dos processos de desgaste para obtenção dos espécimes, o que justificou os baixos resultados de resistência encontrados nesses dois grupos. A alta resistência adesiva dos reparos promovidos com silano foi explicada pela sua capacidade de remoção da camada orgânica depositada na superfície, combinada com o tratamento químico do próprio silano sobre as partículas de carga expostas.

CHIN; TYAS; GOLDMAN²5, em 1987, testaram a resistência adesiva na interface de espécimes de resinas compostas usadas incrementalmente, onde a primeira camada foi polimerizada em contato com ar ou com uma matriz. Neste estudo foram utilizados compósitos híbridos e de partículas pequenas, foto ou quimicamente polimerizáveis. O teste empregado foi o de resistência transversa de três pontos e para tanto foram confeccionados corpos-de-prova em forma de bastões. O teste de resistência foi realizado 23 horas após o armazenamento dos bastões inteiros e reparados em água a $37^{\circ} \mathrm{C}$. Os resultados obtidos mostraram que os reparos realizados com o mesmo material foram mais resistentes que os reparos 
com materiais diferentes. De um modo geral, as amostras polimerizadas expostas ao ar forneceram valores de resistência maiores que as polimerizadas contra uma matriz metálica polida. Este fato foi atribuído à formação de uma camada superficial não polimerizada, graças à presença de oxigênio do ar, que seria responsável por uma maior adesão do incremento subsequente. Dentre todas as combinações testadas, a melhor união foi obtida quando compósitos apresentavam sistemas similares de polimerização. Os autores concluíram que a resistência adesiva entre incrementos depende da natureza da superfície original, assim como da combinação dos materiais utilizados.

POUNDER; GREGORY; POWERS ${ }^{72}$ em 1987, preocupados em esclarecer a questão de reparos realizados em resinas desconhecidas pelo operador no dia-a-dia da clínica, examinaram a resistência adesiva de reparos em resinas compostas com diferentes composições e tamanho de partículas, usando diferentes agentes adesivos. No experimento foram utilizadas: uma resina de macropartículas e uma de micropartículas, ambas quimicamente ativadas, e uma resina de micropartículas fotoativada. Foram confeccionadas quarenta e cinco amostras de cada material e, duas horas depois da polimerização, o processo de reparo foi iniciado. As extremidades dos espécimes foram polidas com lixa 600 e limpas com ácido fosfórico a 37\%, antes da aplicação do agente de união e resina de reparo. Cinco espécimes de cada uma das três resinas recebeu aplicação de um dos três sistemas adesivos e foram reparados com uma das três resinas. Em seguida, as amostras foram armazenadas em água a $37^{\circ} \mathrm{C}$ durante 24 horas e submetidas a testes de resistência à tração. A análise estatística dos resultados obtidos revelaram que nenhuma combinação de resina original, resina de reparo e agente adesivo foi 
capaz de aumentar a resistência adesiva de modo significante. Os valores de reparo não foram superiores à resistência à tração diametral dos compósitos de macro e micropartículas. Os autores concluíram que compósitos de mesma composição e o uso de sistemas adesivos compatíveis não asseguram a obtenção de resistência adesiva adequada em reparos de resinas compostas.

TJAN; GLANCY ${ }^{90}$, em 1988, utilizando um teste de resistência à tração direta avaliaram a resistência adesiva entre camadas de resinas compostas similares e diferentes. Para comparação entre espécimes inteiros e em incrementos o teste de tração diametral também foi executado. Foram elaboradas combinações de materiais de diferentes marcas, e ainda entre resinas convencionais e híbridas com outras de micropartículas. A resistência interfacial dos espécimes experimentais foi geralmente superior à resistência coesiva dos materiais, variando entre $22 \%$ a $32 \%$, dependendo dos compósitos. As resinas de micropartículas a base de uretano dimetacrilato não se mostraram compatíveis com as resinas a base de Bis-GMA, resultando em baixos índices de resistência adesiva. Foi concluído que a execução de restaurações em incrementos produz resistência de união aceitável clinicamente, apresentando valores superiores ou equivalentes à resistência coesiva dos materiais.

Em 1988, ELI et al..$^{34}$ avaliaram a resistência adesiva de duas resinas compostas para dentes posteriores reparadas com materiais iguais ou diferentes. As amostras iniciais foram armazenadas em saliva humana durante 48 horas. Após a lavagem, as superfícies foram tratadas com aplicação de um agente de união ou abrasionamento com disco diamantado, com e sem a interposição de agente de união antes do reparo. Uma comparação entre os grupos controle (espécimes 
inteiros) e os de reparo demonstraram uma superioridade dos primeiros, independentemente da combinação entre materiais ou tratamento de superfície empregados. Não foram encontradas diferenças entre os reparos realizados com resinas compostas iguais ou combinações, porém, quanto aos tratamentos de superfície, no grupo onde os espécimes foram abrasionados e sem aplicação de agente de união houve uma redução significante de resistência adesiva, quando comparado aos demais grupos. O armazenamento dos espécimes em saliva durante 48 horas não afetou a resistência dos reparos. Os autores concluíram que o abrasionamento da superfície de compósitos a serem reparados não é recomendável. Por outro lado, o adequado molhamento da interface com a aplicação de um agente adesivo foi considerado essencial.

KAO, PRYOR; JOHNSTON ${ }^{49}$, em 1988, executaram um trabalho medindo a resistência adesiva entre compósitos de composições químicas semelhantes e diferentes, determinando a influência de agentes adesivos e do armazenamento em água sobre a resistência dos reparos. Dentre os espécimes de cada material, metade foi exposta ao ar durante 10 minutos e os demais foram armazenados em água durante 24 horas. Antes da adição da resina de reparo, metade dos espécimes de cada grupo de armazenamento foi submetida à aplicação de agente adesivo. Após os reparos, todos os espécimes foram armazenados em água a $37^{\circ} \mathrm{C}$ durante 7 dias, antes dos testes de resistência transversa. Os resultados demonstraram que a resistência dos reparos foi afetada significantemente pelo emprego dos agentes adesivos e pelo método de armazenamento. A resistência transversa do grupo exposto ao ar variou de $22 \%$ a $47 \%$ da resistência do grupo controle, aumentando para $40 \%$ a $90 \%$, quando o agente de união foi empregado. Para o grupo de 
armazenamento em água, os valores de resistência variaram de $11 \%$ a 37\% com relação ao controle, tendo aumentado para $35 \%$ a $84 \%$ com o uso de agente adesivo. Segundo os autores, o emprego de um agente de união assegurou um aumento da resistência quando o substrato resinoso foi contaminado com água.

Os agentes silanizadores começaram a ser empregados inicialmente como coadjuvantes em procedimentos de reparo sobre superfícies de porcelana e somente mais tarde foram indicados nos procedimentos de reparo em resina composta. Em 1988, LACY et al. ${ }^{54}$ investigaram o efeito de seis diferentes tratamentos de superfície sobre a resistência de reparos de resina composta em corpos-de-prova de porcelana. As superfícies foram preparadas com pontas diamantadas e gel de flúor fosfato acidulado a 1,23\% ou gel de ácido fluorídrico a 9,5\%. Após tratamento inicial das superfícies foi aplicado também um agente adesivo ou associado a um silano. A análise dos resultados indicou que a aplicação do silano foi essencial para aumentar a resistência adesiva dos reparos. Em contrapartida, quando o silano não foi utilizado a resistência dos reparos foi relativamente baixa, independente do tipo de tratamento de superfície realizado inicialmente. Não houve diferença entre os grupos tratados com ácido fluorídrico e flúor acidulado, ambos resultando em resistência significantemente maior que todos os outros grupos. Os autores concluíram que a combinação entre o agente silano em associação e o condicionamento ácido da superfície proporciona uma adesão mais resistente que a própria resistência coesiva da porcelana.

ARIETA $^{7}$, em 1989, verificou a influência do tipo de material e do fator idade sobre a resistência de união de reparos em resinas compostas. Espécimes em forma de halteres foram confeccionados a partir de uma matriz metálica dividida. 
Amostras inteiras foram consideradas como controle. As amostras reparadas, foram obtidas a partir de amostras inteiras armazenadas (1 hora e 1 semana) e seccionadas ao meio. As superfícies a serem reparadas foram tratadas com ácido fosfórico a $37 \%$ e agente de união, e o reparo foi realizado com resina igual à original ou com outro material. Os resultados dos testes de tração demonstraram que, para as três resinas compostas utilizadas como remanescentes, os espécimes resultaram em valores razoáveis de resistência, quando comparados aos espécimes inteiros. O fator idade influenciou diferentemente para cada combinação, sendo os espécimes de 1 semana, de um modo geral, mais resistentes que os de 1 hora de armazenamento.

ELIADES; CAPUTO ${ }^{35}$, também em 1989, desenvolveram um estudo para avaliar a resistência ao cisalhamento entre incrementos de resina composta na presença da camada não polimerizada, inibida pelo oxigênio, e o efeito de vários tratamentos interfaciais sobre essa resistência. Foram utilizados diferentes resinas compostas para a confecção dos corpos-de-prova. Por sua vez, estes foram confeccionados por incrementos sendo que o primeiro incremento recebeu os seguintes tratamentos: nenhum tratamento, agente de união polimerizado durante 10 segundos, agente de união não polimerizado, desgaste da superfície com ponta diamantada e lavagem da superfície com acetona. Após a inclusão da segunda porção de resina, todos os espécimes foram armazenados em solução salina a $37^{\circ} \mathrm{C}$ durante 24 horas e submetidos aos testes de resistência ao cisalhamento. As superfícies fraturadas foram observadas em estereomicroscópio para determinação dos modos de fratura. Três espécimes adicionais para cada grupo foram preparados para a avaliação da topografia interfacial. De acordo com os resultados, a resistência 
das amostras com dois incrementos foi consideravelmente inferior à resistência das amostras inteiras (controle). A presença da camada inibida por oxigênio reduziu substancialmente a resistência adesiva entre incrementos, criando uma descontinuidade na interface provocada por diferença na contração e ineficiência de polimerização. Dentre os tratamentos testados, o emprego de acetona acarretou em remoção da camada de inibição, com conseqüente aumento significante na resistência e melhor topografia interfacial dos reparos.

Em 1989, CHIBA, HOSODA, FUSAYAMA ${ }^{24}$, avaliaram a resistência de união em adições de resina composta utilizando diferentes tratamentos superficiais, como o uso de matriz de celulóide, polimerização da resina exposta ao ar e desgaste da superfície com broca. Os espécimes foram testados imediatamente após contaminação com saliva artificial durante 30 segundos, 7 dias e 3 meses. Antes da adição da resina do reparo, os espécimes foram tratados com: ácido fosfórico em gel a $40 \%$, aplicação de agente de união, lavagem com escova em forma de cone ou desgaste com broca carbide. O teste de tração foi efetuado após armazenamento das amostras em água a $37^{\circ} \mathrm{C}$ durante 24 horas. Os autores concluíram que a contaminação momentânea foi removida efetivamente pelo ácido fosfórico, ao passo que a contaminação a longo prazo somente foi removida com a redução da superfície com broca. A aplicação de um agente adesivo sobre as superfícies contaminadas durante 30 segundos e desgastadas com broca aumentou a resistência à tração, provavelmente devido à ligação química com as partículas de sílica expostas pelo desgaste. As superfícies desgastadas com broca, submetidas ao condicionamento ácido e aplicação de agente de união, resultaram em um aumento significante na resistência adesiva dos reparos. 
Objetivando identificar tratamentos adequados para 0 reparo de superfícies desgastadas de resinas auto e fotopolimerizáveis CRUMPLER et al. ${ }^{28}$, em 1989, realizaram um estudo empregando uma avaliação seqüencial dos efeitos de várias técnicas mecânicas de tratamento de superfície, agentes químicos de condicionamento e adesivos. Os espécimes foram .envelhecidos durante 7 dias em saliva artificial a $37^{\circ} \mathrm{C}$ e tiveram suas superfícies abrasionadas com brocas ou pontas diamantadas, tratadas com diferentes condicionadores químicos e submetidas à ação de vários agentes de união. Após a polimerização da resina de reparo, os espécimes foram novamente armazenados em saliva artificial durante 7 dias e testados quanto à resistência ao cisalhamento. Os valores médios de resistência dos grupos testados variaram de $77 \%$ a $102 \%$ da resistência coesiva de cada material. A técnica de preparo mecânico da superfície responsável pelo aumento da resistência foi o abrasionamento com ponta diamantada. Quanto ao condicionamento químico, as aplicações de metil-metacrilato, água destilada e ácido fosfórico demonstraram os maiores valores de resistência. Entre os vários agentes de união testados um adesivo dentinário resultou em valores superiores estatisticamente aos demais. Segundo os autores a melhor combinação testada foi o uso de ponta diamantada, limpeza da superfície com água destilada e aplicação de agente adesivo dentinário.

SAUNDERS ${ }^{80}$, em 1990, realizou um estudo comparativo onde analisou os efeitos da fadiga provocada por força de impacto sobre a resistência transversa de reparos em resinas compostas para dentes posteriores. Espécimes retangulares de cada material foram confeccionados e armazenados em água destilada a $23^{\circ} \mathrm{C}$ durante 3 semanas. As superfícies a serem reparadas foram polidas e tratadas com 
um agente silano, um adesivo dual ou mantidas sem tratamento adicional. Os reparos foram executados com o mesmo material do corpo-de-prova original. As amostras foram termocicladas e testadas seqüencialmente sob uma força cíclica de impacto. Um número de 5000 ciclos foi determinado e todos os espécimes foram testados imersos em água a temperatura ambiente. A análise estatística dos limites médios de fadiga para cada condição demonstrou que a resistência ás forças de impacto nos espécimes reparados foi menor que a dos espécimes não reparados (29\% a 95\%). A aplicação de um agente de união dual resultou em reparos mais resistentes, enquanto o emprego de silano não foi capaz de aumentar a resistência à fadiga dos reparos em nenhum dos grupos testados.

CROLL $^{27}$, em 1990, relatou uma seqüência clínica de reparo em uma restauração de Classe I em resina composta, apresentando defeito nas margens. Foi realizada a remoção de toda a superfície original da restauração a fim de expor uma camada de resina que não tivesse sido exposta ao contato direto com o meio oral. Com o intuito de aumentar a retenção do novo compósito, uma resina sem carga foi utilizada após o condicionamento da superfície desgastada com ácido fosfórico a $40 \%$ durante 30 segundos. Pelo mesmo motivo, o autor recomendou o preparo da região onde se localiza o defeito por meio de retenções mecânicas com broca cone invertido. Estas "canaletas" poderiam ser preparadas também na resina original para aumentar a área de superfície na interface de reparo e promover um embricamento mecânico. A aplicação do material de reparo foi realizado em incremento único e com o auxílio de uma seringa. Após a fotopolimerização, a forma anatômica do elemento dentário foi estabelecida com o emprego de brocas de 12 lâminas. Um selante de superfície foi então utilizado sobre o esmalte e a restauração, para 
minimizar o potencial de microinfiltração através de fendas marginais.

GREGORY; POUNDER; BAKUS ${ }^{41}$, em 1990, realizaram um estudo utilizando espectroscopia de reflexão interna múltipla para determinação da presença de duplas ligações, além de um teste flexural de três pontos para avaliar a resistência necessária para fraturar espécimes reparados. Três resinas híbridas fotopolimerizáveis e seus respectivos sistemas adesivos foram empregados. Espécimes inteiros e reparados foram confeccionados com o mesmo material ou resinas diferentes. Os resultados demonstraram a evidência de duplas ligações de carbono na superfície polimerizada de resinas com matriz de Bis-GMA, dimetacrilato de uretano e com mistura dos dois componentes. Com relação à resistência flexural dos reparos, nenhum dos espécimes reparados demonstrou maior resistência que os espécimes inteiros. Os reparos realizados com resinas de matrizes iguais não foram capazes de produzir resistência maior que aqueles realizados com resinas de matrizes diferentes. Apesar de diferenças significantes nos valores de resistência entre várias combinações, não houve incompatibilidade entre os reparos. A disponibilidade de duplas ligações de carbono na resina polimerizada para reagir com a resina de reparo permitiu a adesão entre ambas as superfícies. Quanto à localização das fraturas, elas ocorreram principalmente na interface adesiva (74\%) ou próximo a esta área, e foram atribuídas à inclusão de bolhas de ar ou desadaptações próximas á interface.

Parte do sucesso dos procedimentos de reparo deve-se à alteração física da superfície a ser reparada, de modo a propiciar a formação de retenções micromecânicas que promovam uma adequada adesão interfacial $1^{1}$. Com o objetivo de demonstrar o padrão de condicionamento de alguns agentes ácidos, AL EDRIS et 
al. ${ }^{1}$, em 1990, realizaram um estudo com microscopia eletrônica de varredura em superfícies de três diferentes porcelanas comerciais. Os espécimes foram confeccionados e abrasionados com jatos de óxido de alumínio ou mantidos com glaze. $\mathrm{O}$ condicionamento das superfícies foi realizado com 3 diferentes agentes condicionadores ácidos. Os espécimes foram preparados e observados em microscópio eletrônico de varredura. $\mathrm{O}$ tratamento ácido das superfícies glazeadas produziu padrões de condicionamento menos proeminentes que o das superfícies abrasionadas. O ácido fluorídrico em conjunção com outros ácidos foi capaz de promover um padrão de condicionamento considerado efetivo em todas as porcelanas testadas. Ao contrário, o gel de flúor acidulado produziu padrões superficiais de condicionamento, resultando em superfícies rugosas, mas não retentivas suficientes para assegurar o sucesso de um procedimento de reparo.

SÖDERHOLM; ROBERTS ${ }^{85}$ em 1991, buscaram determinar a influência de diferentes condições, como a idade do compósito, o armazenamento em água e o agente adesivo sobre a resistência de reparos. Barras retangulares de resina composta foram confeccionadas e armazenadas a seco a $37^{\circ} \mathrm{C}$ durante 24 horas e 60 dias. Todas as amostras foram tratadas com ácido fosfórico durante 60 segundos e receberam a aplicação de "primer" e adesivo, somente o adesivo ou ainda, tolueno-silano, "primer" e adesivo. Outros espécimes não receberam nenhum tratamento além do condicionamento ácido. Todas as amostras, incluindo um grupo com espécimes não reparados, foram armazenadas por mais 24 horas a $37^{\circ} \mathrm{C}$ e divididas em dois subgrupos, os quais foram armazenados em água destilada a $37^{\circ} \mathrm{C}$ durante 3 e 12 meses. A resistência dos espécimes foi medida por teste flexural de 4 pontos. Os espécimes não reparados não apresentaram diferenças na 
resistência após armazenamento por 3 ou 12 meses em água, e demonstraram-se mais resistentes que todos os grupos experimentais. Estes não apresentaram diferenças com relação ao tempo de armazenamento em seco antes do reparo ( 1 e 60 dias). Porém, todos os espécimes, incluindo os controles, sofreram uma redução na resistência após um longo período em água. Os grupos onde foram utilizados somente adesivo, primer e adesivo, ou tolueno, primer e adesivo apresentaram resistências semelhantes entre si. Após ambos os períodos de 90 e 360 dias em água, a resistência dos espécimes reparados variou de $25 \%$ a $50 \%$ da resistência coesiva dos espécimes controle. Os autores concluíram que a retenção mecânica é o principal mecanismo envolvido nos reparos em resinas compostas.

MITSAKIMATSOU et al. ${ }^{64}$, em 1991, diante da necessidade de se conhecer a efetividade de reparos feitos com diferentes materiais, mediram a resistência à tração de resinas auto e fotoativadas reparadas com o mesmo ou outro compósito. A resistência foi avaliada em função da idade do substrato ou do tratamento de superfície empregado. Trezentos e dez espécimes foram confeccionados e armazenados em água destilada a $37^{\circ} \mathrm{C}$ durante 48 horas, 7 dias e 1 ano. Em 30 amostras do grupo de armazenamento de 1 ano um agente adesivo foi utilizado antes do reparo, enquanto o restante dos espécimes, em todos os períodos de armazenamento foram somente abrasionados com lixas de granulação 240 a 600. Todas as amostras foram mantidas em temperatura ambiente durante 30 minutos, antes do teste de resistência à tração. Cinco espécimes inteiros de cada resina foram também testados como controles. Os valores de resistência dos reparos variaram de $40 \%$ a $59 \%$ em 48 horas, quando comparados à resistência dos espécimes inteiros. Em um período de 7 dias, os índices variaram de 18\% a 52\% e 
em 1 ano de armazenamento, $11 \%$ a 57\%. A aplicação do agente adesivo nos espécimes envelhecidos durante 1 ano aumentou significantemente a resistência dos reparos em todos, com exceção de um grupo. Os resultados deste estudo demonstraram que o abrasionamento da superfície de resina reduziu a resistência dos reparos, os autores atribuíram este fato à exposição das partículas inorgânicas da carga. Por outro lado, a adição da resina sem carga de baixa viscosidade (agente adesivo) reforçou significantemente os reparos em resina composta.

Ainda com a preocupação de determinar a influência da idade do substrato, do tipo de resina e do sistema adesivo, PUCKETT; HOLDER; O'HARA ${ }^{73}$, em 1991, avaliaram a resistência de reparos realizados em resinas compostas sob diferentes condições. O objetivo principal foi chamar a atenção para as conseqüências clínicas de reparos em resinas posteriores com um material diferente do original. Três resinas compostas fotopolimerizáveis para dentes posteriores e seus respectivos sistemas adesivos foram investigados. As condições testadas foram o reparo com o mesmo material, com ou sem seu respectivo agente adesivo, e reparo com os outros materiais e seus respectivos agentes adesivos. Os espécimes foram fabricados e imersos em solução de Ringer a $37^{\circ} \mathrm{C}$ durante 24 horas. Após o envelhecimento, dez espécimes de cada material foram usados como controle, para determinação da resistência de cada compósito. Os demais foram preparados com lixa de granulação 240 , para receberem os tratamentos antes de receberem a resina do reparo. A resistência dos reparos variou de $20 \%$ a $60 \%$ da resistência diametral das resinas compostas. Todos os espécimes onde um sistema adesivo foi utilizado apresentaram resistência significantemente maior, quando comparados aos espécimes sem adesivos. A inspeção das fraturas ao microscópio 
demonstrou que todas ocorreram na interface adesiva. Os maiores valores de resistência foram obtidos quando uma resina a base de Bis-GMA, associada a um adesivo dentinário, foi utilizada como material de reparo para substratos a base de Bis-GMA e UDMA. Todos os reparos realizados sobre resinas de UDMA resultaram em resistência aceitável clinicamente, contrariamente aos reparos em resinas de Bis-GMA sem sistema adesivo.

A fim de verificar qual o melhor sistema adesivo a ser empregado nos procedimentos de reparo, HOLDER et al. ${ }^{45}$, em 1991, compararam a resistência à tração diametral de reparos em resina composta para dentes posteriores, utilizando sistemas adesivos de primeira, segunda e terceira gerações. Os espécimes de resina foram preparados, envelhecidos em solução de Ringer durante 7 dias, desgastados com lixa de granulação 240 e, finalmente, reparados com um dos sistemas adesivos e a mesma resina composta do corpo-de-prova inicial. As amostras foram armazenadas por mais 7 dias antes de serem testadas. Os resultados indicaram que os reparos executados œm o sistema adesivo de terceira geração foram os menos resistentes, enquanto o de segunda geração resultou nos maiores valores de resistência. Contudo, a análise estatística dos dados não demonstrou diferenças significantes entre os grupos experimentais. Os autores sugeriram que a incorporação de monômeros hidrofílicos, visando o aumento da adesão à dentina, poderia ser responsável pela redução da capacidade de molhamento e de adesão do agente de união de terceira geração às superfícies abrasionadas de resina composta.

Ainda em 1991, ARITA et al. ${ }^{8}$ analisaram o efeito da termociclagem sobre a resistência de reparos de resina composta. Os autores realizaram um estudo onde 
espécimes de duas resinas híbridas e uma de micropartículas foram confeccionados e armazenados em saliva artificial durante 7 dias. Espécimes controle foram obtidos utilizando cada um dos compósitos. Após o período de armazenagem, as amostras foram lavadas com água destilada ou polidas com lixa de granulação 400, tratadas com ácido fosfórico e agente adesivo. Os reparos foram realizados com as mesmas resinas compostas e combinações entre os materiais. Os corpos-de-prova reparados foram acondicionados durante 2 dias em saliva artificial e então foram termociclados $\left(0,1.000,10.000\right.$ ciclos a 5 e $\left.50^{\circ} \mathrm{C}\right)$ e submetidos ao teste de resistência transversa. Os resultados demonstraram que os espécimes controle de resinas híbridas foram mais resistentes que os espécimes de resina de micropartículas. Apesar dos espécimes reparados apresentarem resistência inferior aos espécimes controle (23\% a $51 \%$ ), houve diferença significante entre os valores, quando os grupos que tiveram suas superfícies tratadas foram comparados com os espécimes somente lavados com água. A termociclagem provocou redução na resistência transversa para todos os grupos estudados inclusive aqueles com espécimes não reparados. Os autores sugeriram que reparos com diferentes materiais sejam precedidos de polimento, tratamento com ácido e agente adesivo, para garantir resistência adesiva aceitável na interface.

Utilizando seis resinas de formulação conhecida, em 1992, FERRACANE; MARKER $^{36}$ buscaram determinar os efeitos do tipo e tamanho das partículas de carga, assim como a temperatura da polimerização secundária, sobre a energia de fratura (fracture toughness) de compósitos armazenados por até 1 ano em etanol e água. As resinas compostas de partículas de quartzo e vidro de bário revelaram uma redução significante na resistência após 1 ano em etanol, idêntica à redução 
resultante de 2 meses em água. Este fato foi atribuído ao amolecimento da matriz resinosa, e as trincas encontradas na interface carga/matriz, reveladas pela observação em microscópio eletrônico de varredura. As trincas observadas nas resinas envelhecidas em água não foram consideradas significantes. $O$ armazenamento em água durante 1 ano exerceu pouca influência sobre a energia de fratura dos compósitos polimerizados sob temperatura bucal, mas um aumento significante foi relatado para os compósitos submetidos à polimerização secundária a altas temperaturas.

Em 1992, SWIFT JÚNIOR et al. ${ }^{89}$ desenvolveram um estudo onde vários métodos de tratamento da superfície para reparos de resinas compostas indiretas foram avaliados. Os tratamentos testados incluíram jateamento com partículas de óxido de alumínio, condicionamento com ácido fluorídrico a 9,6\%, silanização e combinações destes tratamentos. A resistência ao cisalhamento foi medida após os respectivos tratamentos e aplicação de um sistema de cimentação adesiva dual. Metade dos espécimes foram armazenados em água e o restante termociclado por 500 ciclos. O jateamento com óxido de alumínio promoveu a maior e mais consistente resistência adesiva, com ou sem a associação com silano. O tratamento com ácido fluorídrico reduziu significantemente a resistência dos espécimes, mesmo quando precedido de abrasionamento com óxido de alumínio e seguido de silanização. Os menores valores de resistência foram obtidos com o condicionamento com ácido fluorídrico, onde a maior parte das falhas foram adesivas entre o cimento dual e a resina indireta. Os autores concluíram que a silanização pode aumentar a adesão de resinas indiretas abrasionadas com jatos de óxido de alumínio. O uso de ácido fluorídrico foi desaconselhado, uma vez que reduz 
consideravelmente a resistência adesiva nos casos de reparos em resinas compostas indiretas.

GREGORY et al. ${ }^{42}$, em 1992, realizaram um estudo buscando determinar o grau de conversão das resinas compostas e comparar sete propriedades físicas e a resistência dos reparos entre duas resinas de uso direto e três de uso indireto. Os corpos-de-prova foram confeccionados em uma matriz e armazenados em água a $37^{\circ} \mathrm{C}$ durante 24 horas. Após este período, as superfícies foram abrasionadas com um disco de óxido de alumínio e tratadas com ácido fosfórico a 37\% durante 60 segundos. Um agente de união foi aplicado, e os espécimes foram então reparados com resina composta Herculite XR. A resistência dos espécimes foi avaliada por meio de um teste de resistência flexural de três pontos. A localização das fraturas foi determinada com a observação em microscópio com aumento de 13 vezes. A análise dos resultados não detectou diferenças entre os grupos de reparo. Com relação ao tipo de fratura, não ocorreram fraturas do tipo coesiva, e sim, adesivas na interface e mistas. O estudo demonstrou que as ligações nos reparos foram limitadas à adesão química. As resinas de uso indireto, com maior resistência flexural, apresentaram um maior índice de conversão, o que se refletiu em baixa resistência adesiva dos reparos com estes compósitos.

A fim de avaliar a efetividade de alguns tratamentos sobre a resistência adesiva de reparos de resina composta, SWIFT JÚNIOR; LE VALLEY; BOYER ${ }^{88}$, em 1992, realizaram um trabalho empregando cinco compósitos de diferentes composições e tamanhos de partículas. Espécimes inteiros foram utilizados como controle. Dez amostras de cada grupo receberam diferentes tratamentos de superfície, como jateamento com partículas de óxido de alumínio de $50 \mu \mathrm{m}$, o 
mesmo tratamento seguido de condicionamento com ácido fluorídrico a 9,6\% ou gel de flúor fosfato acidulado a 1,23\%. Em seguida, procedeu-se a aplicação de um agente de união e reparo com o mesmo material do espécime inicial. Depois de um período de armazenamento em água de 24 horas, os espécimes foram submetidos ao teste de resistência flexural de 3 pontos. As observações em microscópio eletrônico demonstraram um aumento substancial da rugosidade superficial com a utilização de jato de óxido de alumínio, enquanto o efeito do ácido fluorídrico e flúor fosfato acidulado foram aparentes. Os resultados indicaram que o condicionamento com ácido fluorídrico não aumentou de modo significativo a resistência dos reparos, por outro lado afetou de maneira adversa o reparo em alguns compósitos. O gel de flúor fosfato acidulado aplicado durante 10 minutos reduziu a resistência dos reparos. Porém, o abrasionamento da superfície de resina com jato de óxido de alumínio propiciou uma superfície mecanicamente retentiva para a realização de reparos. Os autores sugeriram que, em casos onde a composição das resinas que requerem reparo for desconhecida, deve ser evitado o uso rotineiro de géis condicionadores ácidos, e sim aplicar métodos de abrasionamento mecânicos.

Em 1993, com objetivo de analisar a composição, reatividade, interações superficiais e modo de ação de três primers silano disponíveis no mercado, ANAGNOSTOPOULOS; ELIADES; PALAGHIAS ${ }^{5}$ realizaram uma pesquisa utilizando dois agente silanizadores pré-hidrolisados e um quimicamente ativado. A estrutura molecular dos silanos foi analisada por meio de espectroscopia de reflexão interna múltipla (MIR-FTIR). O potencial de reatividade dos silanos, estimado pela quantidade de grupos metoxi por átomo de Si hidrolisados em silanol, foi analisada por meio de espectroscopia FT-NMR. Os autores explicam que os grupos silanóis 
são as áreas ativas das moléculas hidrolisadas de silano, portanto, quanto maior sua quantidade melhor o comportamento reativo do material. De acordo com os resultados, todos os primers continham $\gamma$-metacriloxipropiltrimetoxisilano ( $\gamma$-MPTS), dois deles em etanol e um em isopropanol. Nos silanos pré-hidrolisados, foram encontrados traços de ácido acético, que supostamente funcionaria como um catalisador para a hidrólise e condensação das moléculas de silano. Todos os produtos demonstraram hidrólise parcial dos grupos metoxi, porém um maior índice de hidrólise foi atribuído aos primers pré-hidrolisados, quando comparados com os quimicamente ativados. Este fato foi explicado pela alta concentração de $\gamma$-MPTS nos sistemas de dois componentes, favorecendo a condensação dos grupos silanóis, ao invés da formação de pontes de hidrogênio com a superfície do substrato.

Em 1993, TURNER; MEIERS ${ }^{91}$ investigaram a resistência ao cisalhamento de uma resina composta de uso indireto reparada com uma resina direta fotopolimerizável, usando diferentes tratamentos de superfície e sistemas adesivos. Noventa espécimes inteiros foram preparados e cortados ao meio com ponta diamantada. Em seguida, os mesmos foram termociclados por 5.000 ciclos, com banhos de $5^{\circ} \mathrm{C}$ e $55^{\circ} \mathrm{C}$. Os corpo-de-prova foram então contaminados com solução de tabaco durante 7 dias. Foram utilizadas amostras inteiras (controle) para determinação da resistência coesiva do material. As superfícies foram abrasionadas com lixa 500 ou jateadas com partículas de óxido de alumínio durante 3 segundos e limpas com ácido fosfórico a 37\%. Três diferentes sistemas adesivos, um agente de união ou de uma resina de micropartículas foram utilizados para o reparo. Além destes, um grupo foi reparado sem a utilização de nenhum agente adesivo 
intermediário. Os espécimes reparados foram ainda termociclados por 5.000 ciclos antes de serem submetidos ao teste de resistência. $O$ jateamento com óxido de alumínio produziu resistência superior ao polimento com lixas abrasivas, para todos os sistemas adesivos empregados. O sistema All-Bond demonstrou os maiores valores de resistência adesiva quando comparado a outros sistemas empregados. As observações microscópicas demonstraram que o jateamento com óxido de alumínio acarretou em superfícies mais rugosas que as tratadas com lixas. Ao analisar as fraturas, os autores observaram que elas foram predominantemente adesivas, ou seja no longo da interface substrato/reparo. Neste estudo, a retenção mecânica, ao invés da ligação química, foi capaz de promover urna força adesiva efetiva nos reparos de uma resina composta indireta reparada com uma resina direta.

SWIFT JÚNIOR; CLOE; BOYER ${ }^{87}$ em 1994, realizaram um estudo cujo objetivo foi de avaliar a efetividade de um agente silanizador para o reparo de resinas compostas. Foram confeccionadas barras de resina composta híbrida para determinar a resistência coesiva. Após um período de 120 dias de armazenamento em água, os espécimes experimentais foram submetidos a tratamentos como jato de óxido de alumínio, ácido fluorídrico a 9,6\% ou uma associação de ambos. Em seguida, metade dos espécimes tratados de cada grupo recebeu a aplicação de silano e todos receberam uma camada de adesivo antes da inserção da resina de reparo. Antes de serem submetidos ao teste de resistência transversa, as amostras foram armazenadas em água durante 7 dias. $\mathrm{O}$ tratamento de superfície inicial que forneceu os maiores valores de resistência foi o jateamento com óxido de alumínio atingindo $62 \%$ da resistência coesiva da resina, enquanto sua associação ao ácido 
fluorídrico atingiu valores correspondentes a $41 \%$. As resistências de todos os reparos foram significantemente menores que a resistência coesiva do material, mas não diferentes entre si. A silanização aumentou a resistência dos reparos submetidos ao jateamento associado ao ácido fluorídrico, mas reduziu a resistência dos espécimes somente jateados. Os autores concluíram que a sorpção de água pelo compósito pode ter contribuído redução da força coesiva e dos reparo observadas neste estudo.

MATSUMURA; HISAMATSU; ATSUTA ${ }^{59}$, em 1995, avaliaram o efeito de agentes adesivos e um primer silano sobre a adesão entre camadas de uma resina composta de micropartículas. Três sistemas adesivos com diferentes composições foram utilizados (UDMA, MMA-UDMA e TEGDMA). Os espécimes de resina foram confeccionados e depois de polidos com lixa 600 foram abrasionados com disco de carborundum. Para cada grupo que recebeu um dos três sistemas adesivos, metade dos espécimes recebeu, anteriormente à camada de adesivo, uma camada de silano e em seguida o reparo foi realizado. As amostras reparadas foram imersas em água a $37^{\circ} \mathrm{C}$ ou armazenadas a seco por períodos de 24 horas, 3 e 6 meses e 1 ano. Os testes de resistência ao cisalhamento foram realizados e as superfícies fraturadas observadas em microscópio óptico. Os resultados demonstraram que a resistência aumentou significantemente com o uso de silano e dos três agentes adesivos. Os espécimes tratados com silano e armazenados em água foram mais resistentes que os armazenados a seco. De um modo geral, a resistência dos grupos tratados com silano aumentou com o tempo. Quanto aos modos de fratura, todos os grupos não tratados com silano apresentaram fraturas adesivas, enquanto os grupos com silano apresentaram falhas adesivas com propagação de trincas e coesivas em ambas as 
superfícies. Os maiores valores de resistência foram atribuídos à combinação silano e adesivo à base de TEGDMA, com falhas coesivas na maior parte dos espécimes. Os autores concluíram que é recomendável o uso da combinação silano/adesivo quando uma resina composta for adicionada à superfície desgastada de uma resina previamente polimerizada.

KUPIEC; BARKMEIER ${ }^{52}$, em 1996, avaliaram a resistência de reparos em resina composta indireta de polimerização secundária, usando vários tratamentos de superfície. No grupo controle, os espécimes de resina tiveram a camada cuja polimerização é inibida pelo oxigênio mantida. Os demais grupos foram polidos com lixa de granulação 600 e tratados com ponta diamantada ou jato com partículas de óxido de alumínio de $50 \mu \mathrm{m}$. Em metade dos espécimes de cada grupo foi aplicada uma camada de adesivo antes do reparo com a mesma resina indireta. Após 24 horas de armazenamento em água, as amostras foram submetidas aos testes de resistência ao cisalhamento. Os resultados não demonstraram diferença estatisticamente significante na resistência ao cisalhamento entre os reparos onde a camada inibida por oxigênio foi mantida, tratados com ponta diamantada e com jato de óxido de alumínio. Os autores concluíram que o tratamento da superfície de uma resina composta polimerizada afeta significantemente a resistência adesiva dos reparos, ao passo que o uso de uma resina sem carga não exerce influência significativa.

Com objetivo de determinar fatores que poderiam interferir na resistência de resinas compostas aplicadas e polimerizadas sob a técnica incremental, VON BEETZEN et al. ${ }^{95}$, em 1996, desenvolveram um trabalho onde observaram a resistência ao cisalhamento de três diferentes produtos. Duas resinas híbridas e uma 
de micropartículas foram empregadas para a confecção dos espécimes inteiros e em dois incrementos, a partir de uma matriz metálica dividida. O primeiro incremento foi polimerizado sob diferentes condições: exposto ao ar, sob uma lâmina de vidro, ou ainda dentro de câmaras de oxigênio ou de nitrogênio. Todos os espécimes foram armazenados em água destilada a $37^{\circ} \mathrm{C}$ durante 24 horas, antes da realização dos testes de resistência ao cisalhamento. Não foram encontradas diferenças na resistência entre os espécimes polimerizados expostos ao ar e sob lâmina de vidro. Porém, as amostras de dois materiais apresentaram resistência significantemente maior quando polimerizadas em câmara de nitrogênio do que em câmara de oxigênio. Os resultados demonstraram que a resistência adesiva entre os incrementos de resinas compostas foi influenciada pelas propriedades superficiais dos compósitos depois de serem polimerizados sob diferentes condições. As propriedades químicas e físicas inerentes de cada material também exerceram influência na efetividade de adesão entre os incrementos. Os autores sugeriram que as condições ideais para adesão entre camadas de compósitos permanece desconhecida e pode variar para diferentes materiais.

Em 1997, BROSH et al. ${ }^{17}$ avaliaram o efeito da combinação de vários tratamentos de superfície e agentes adesivos sobre a resistência adesiva de reparos confeccionados em uma resina envelhecida. Espécimes cilíndricos foram confeccionados com uma resina híbrida, armazenados em água a $37^{\circ} \mathrm{C}$ durante 14 dias e, então, divididos em 6 grupos, nos quais as superfícies receberam os seguintes tratamentos: ponta diamantada, jateamento com óxido de alumínio, jato de bicarbonato de sódio, pedra verde de carborundum e ácido fluorídrico a 9,5\%, além do controle que não recebeu nenhum tipo de tratamento. Após receberem o 
tratamento inicial, cada grupo foi subdividido em 3 grupos e submetidos à aplicação de um agente de união a base de Bis-GMA ou do mesmo agente precedido da aplicação de um silano, além de um grupo controle sem nenhum sistema adesivo. Em seguida, os espécimes foram reparados com resina de micropartículas e armazenados durante 14 dias. Após este período, foi realizada ciclagem térmica dos espécimes de 300 ciclos, com banhos de temperaturas de $5^{\circ} \mathrm{C}$ e $55^{\circ} \mathrm{C}$. Concluída a termociclagem foi realizado o teste de resistência ao cisalhamento. O uso de agente de união, isoladamente ou combinado com silano, se mostrou o procedimento mais efetivo para aumentar a resistência adesiva de espécimes reparados em resina, independente do tratamento de superfície realizado. A silanização com agente de união aumentou de modo não significante a resistência dos reparos, quando comparados a somente agente de união. Os maiores valores de resistência foram produzidos pelo abrasionamento da superfície com pedra de carborundum e jatos de óxido de alumínio, enquanto os menores foram produzidos pelo condicionamento com ácido fluorídrico. Os autores puderam concluir que diferentes combinações de tratamentos de superfície e sistemas adesivos afetam diferentemente a resistência dos reparos em resina composta.

Em 1997, L ${ }^{56}$ mediu a resistência ao cisalhamento de um incremento polimerizado a outro incremento recém polimerizado do mesmo compósito utilizando vários tratamentos de superfície. Seis diferentes resinas compostas foram empregadas no estudo. Os espécimes correspondentes ao primeiro incremento foram polimerizados sobre uma lâmina de vidro e, em seguida, tratados com um dos seguintes processos: aplicação de acetona durante 2 minutos, polimento com lixa 400 ou polimento e tratamento com silano durante 60 segundos. Um grupo controle 
não recebeu nenhum tratamento citado. Um segundo incremento com o mesmo material foi adicionado aos espécimes e fotopolimerizado. As amostras foram imersas em água deionizada a $37^{\circ} \mathrm{C}$ durante 24 horas antes dos testes de cisalhamento. A remoção da superfície, com polimento ou acetona, produziu uma redução na resistência adesiva dos espécimes. O tratamento com silano foi capaz de recuperar parte dessa redução, correspondendo a $50 \%$ ou menos da resistência original apresentada pelo grupo controle. Portanto, foi sugerido que a camada, cuja polimerização é inibida pelo oxigênio, parece agir como um adesivo que une quimicamente os dois incrementos de resina. O polimento mecânico ou lavagem com acetona removeram esta camada, reduzindo a resistência adesiva interfacial. O tratamento com agente silanizador foi recomendado nos casos onde o substrato é constituído de uma superfície polida.

Em 1997, buscando avaliar a resistência de reparos em restaurações indiretas de resinas compostas, DAVIES et al. ${ }^{29}$ realizaram um estudo empregando uma resina indireta reparada com resinas compostas aplicadas de modo direto e polimerizada convencionalmente. Os reparos foram realizados com uma das três resinas diretas selecionadas para o trabalho, com ou sem a adição de seus respectivos sistemas adesivos. Como controle, foram confeccionadas amostras inteiras. Todos os espécimes foram armazenados em temperatura ambiente durante 24 horas antes dos testes de tração diametral. A resistência de todos os reparos foi significantemente inferior à dos espécimes controle, sendo o maior valor correspondente a $83 \%$ da resistência coesiva da resina original. A utilização de um agente de união foi fundamental para minimizar a redução na resistência dos reparos. Os autores sugeriram uma seqüência para procedimentos de reparo de 
restaurações em resina composta indireta fraturadas, salientando que o operador deveria evitar áreas sujeitas a contatos oclusais intensos.

No mesmo ano, KUPIEC, SVENSON; BARKMEIER ${ }^{53}$ avaliaram diferentes tratamentos de superfície para o reparo de uma resina composta indireta. Todos os espécimes tiveram as superfícies polidas com lixas de granulação 600, com exceção do grupo controle, onde foi mantida a camada inibida pelo oxigênio. Outros tratamentos testados foram o abrasionamento com ponta diamantada e jateamento com partículas de óxido de alumínio. Metade das amostras de cada grupo foi tratada adicionalmente com uma camada de adesivo antes da adição da resina de reparo. A resistência ao cisalhamento foi determinada após armazenamento em água destilada a $37^{\circ} \mathrm{C}$ durante 24 horas e 60 dias e termociclagem. A análise dos resultados não demonstrou diferenças entre os grupos tratados com jateamento, com e sem adesivo, e o grupo onde a camada inibida foi preservada. Os reparos realizados sobre superfícies polidas com lixas apresentaram os menores valores de resistência em ambos os períodos. A resistência dos reparos foi semelhante às mesmas técnicas sem aplicação de adesivo, nos grupos de tratamento com ponta diamantada, jateamento e camada inibida. Baseados nos resultados deste estudo, os autores concluíram que a rugosidade de superfície exerce um papel mais importante que o agente adesivo nos reparos de resinas compostas indiretas.

SHAHDAD; KENNEDY ${ }^{81}$, em 1998,.desenvolveram um estudo que teve como objetivo avaliar o potencial de reparo de duas resinas disponíveis no comércio por meio da resistência adesiva, assim como a efetividade de dois sistemas adesivos como materiais intermediários entre a resina antiga e a do reparo. O efeito do abrasionamento da superfície e a interferência do tempo sob os corpos-de-prova 
reparados também foram observados. Os espécimes que tiveram a superfície abrasionada anteriormente à aplicação da resina de reparo demonstraram maior resistência adesiva. Neste trabalho a utilização dos sistemas adesivos de forma geral também aumentou a resistência dos espécimes reparados, porém sem diferença estatisticamente significante. Para um dos grupos testados, onde a resina do reparo foi a mesma daquela do espécime inicial, e foi realizado o abrasionamento da superfície e aplicação do adesivo, a resistência adesiva foi de $99 \%$ da resistência coesiva do material, observada em corpos de prova não reparados. Não houve diferença estatisticamente significante para os tempos estudados. Os autores concluíram que o abrasionamento e a aplicação do sistema adesivo nas superfícies a serem reparadas aumentam a resistência adesiva dos reparos. Este fato torna o procedimento de reparo clinicamente aceitável e seguro.

LEWIS et al., em 1998, estudaram a resistência de união ao cisalhamento de reparos imediatos de duas resinas compostas (Pertac Hybrid e Z-100). Foram concebidos três grupos de espécimes para cada material resinoso. Em um dos grupos a presença de oxigênio na superfíce não foi permitida, no segundo sim. No terceiro grupo realizou-se um jateamento da superfície de cada corpo-de-prova. Todas as amostras ficaram armazenadas por seis semanas em água a uma temperatura de $23 \stackrel{\circ}{\circ}$. Após a realização dos testes de resistência ao cisalhamento os autores concluíram que os maiores valores obtidos estavam relacionados aos grupos onde havia a presença superficial de oxigênio.

SAL et al., em 1999, avaliaram a resistência de união de diferentes tipos de resinas reparadas com um compósito híbrido. Os autores testaram a resistência ao 
cisalhamento da própria resina híbrida (grupo controle) e observaram que nenhum tipo de reparo foi capaz de atingir os valores alcançados pelo grupo controle.

Em 2001, FREITAS ${ }^{39}$ avaliou a estabilidade de reparos em resina composta, por meio de aplicação de forças de cisalhamento e de tração. No momento do reparo, cada grupo recebeu um tratamento de superfície específico: ácido fosfórico a $35 \%$, ácido fluorídrico a $10 \%$ ou jateamento com partículas de óxido de alumínio de $50 \mu \mathrm{m}$. Tais tratamentos foram seguidos da aplicação de um agente adesivo associado ou não a um agente silanizador. Os espécimes reparados foram armazenados em água destilada por 30 dias e oito meses. Após estes períodos os corpos-de-prova foram levados a uma máquina de ensaios universal e realizados os testes de resistência. Após análise dos resultados a autora verificou que os tratamentos que proporcionaram maior rugosidade superficial obtiveram maior resistência, sendo eles: o jateamento com óxido de alumínio e condicionamento com ácido fluorídrico. Este resultado foi obtido para os dois ensaios propostos, cisalhamento e tração. Ainda, observou que a utilização do agente silano não conseguiu elevar, com significância, a resistência dos reparos quando comparada à aplicação do adesivo isoladamente. Comparando-se os resultados dos testes realizados após 30 (trinta) dias e 8 (oito) meses verificou que o reparo manteve-se estável para os grupos tratados com jateamento de partículas de óxido de alumínio, fato que possibilita a indicação clínica segura deste procedimento.

CESAR et $a l^{21}$ em 2001, realizaram um experimento onde procuraram mensurar a resistência a tração de reparos de restaurações indiretas de resina composta (Artglass) utilizando um compósito de aplicação direta como material restaurador (Charisma). Blocos de Artglass foram divididos em dezoito grupos de 
acordo com o tratamento superficial de eleição: três diferentes tratamentos mecânicos e seis diferentes tratamentos químicos. Para execução dos tratamentos mecânicos foram empregados jateamento com partículas de óxido de alumino, pontas diamantadas e discos de lixa. Já como tratamentos químicos os autores lançaram mão somente da aplicação do sistema adesivo Prime \& Bond 2.1, do condicionamento realizado com ácido fosfórico e posterior aplicação do sistema adesivo mencionado, da aplicação de ácido hidrofluorídrico em tempos distintos (1 e 3 minutos) e inserção do Prime \& Bond 2.1, somente Artglass líquido e por fim silano seguida da inserção do sistema adesivo Prime \& Bond 2.1. Previamente a realização dos testes de tração os corpos-de-prova foram armazenados em água destilada por 24 horas em uma temperatura de $37^{\circ} \mathrm{C}$. Segundo os pesquisadores não houve diferença estatística entre os três tipos de tratamentos mecânicos empregados, exceto para os grupos que utilizaram o Artglass líquido e o silano. Não houve diferença estatística entre o uso do ácido fosfórico e do Artglass líquido quando comparados com a utilização isolada do sistema adesivo. A utilização do ácido hidrofluorídrico por 1 ou 3 minutos reduziu a resistência de união significativamente comparando-se com os demais tratamentos mecânicos. Ainda, de acordo com os autores, a associação do jateamento com a aplicação do silano resultou, de maneira estatisticamente significante, na maior resistência à tração de todos os grupos. A análise da microscopia eletrônica de varredura mostrou que o ácido fosfórico não causou alterações na superfície dos espécimes a serem reparados que passaram previamente por qualquer um dos tratamentos mecânicos. Já o ácido hidrofluorídrico quando associado ao jateamento ou à ponta diamantada produziu a destruição de 
parte da topografia superficial obtida logo após a execução de um dos tratamentos mecânicos citados.

MARTíN; LÓPEZ; MONDELO ${ }^{60}$, em 2001, realizaram um estudo para avaliar a eficácia da realização de reparos em resinas compostas. Para tal propósito, utilizaram diferentes tratamentos superficiais combinados com dois agentes adesivos. Foram preparados 90 espécimes de Herculite e 90 espécimes de Heliomolar, que permaneceram armazenados por 4 semanas. Todos os compósitos foram submetidos a um dos nove tratamentos previamente estabelecidos. As superfícies das restaurações reparadas foram tratadas com diferentes combinações que envolveram o emprego de jateamento superficial, ácido fosfórico, ácido hidrofluorídrico, acetona e os sistemas adesivos: Special Bond II, Heliobond e Prime \& Bond 2.0. A maior resistência de união foi obtida com o jateamento, já o emprego do ácido fosfórico resultou no menor valor. Segundo os autores o emprego do jateamento superficial concomitantemente com o sistema adesivo Prime \& Bond 2.0 aumentou de maneira consistente a resistência de união ao cisalhamento para ambas as resinas compostas testadas.

MELO ${ }^{62}$ em 2001, avaliou a influência de diferentes tratamentos de superfície na resistência à tração de reparos em resina composta, confeccionados sobre uma resina composta de laboratório de segunda geração ( Artglass). Sessenta amostras em Artglass foram incluídas em resina acrílica e divididas em 6 grupos: grupo 1) condicionamento com ácido fosfórico a 35\%; grupo 2) asperizaçäo com ponta diamantada; grupo 3) asperização com discos de lixa; grupo 4) jateamento com óxido de alumínio (50 $\mu \mathrm{m})$; grupo 5) condicionamento com ácido fluorídrico a 9,5\% associado a agente silano e grupo 6) sem tratamento de superfície. Após os 
tratamentos de superfície as amostras receberam aplicação de agente adesivo (PG1) previamente ao reparo com resina composta (Amelogen). O grupo 6 (controle) não recebeu tratamento de superfície ou agente adesivo antes do procedimento de reparo. Os corpos-de-prova foram testados quanto a resistência à tração em máquina de testes universal (Instron), e os resultados submetidos à análise estatística. As médias (MPa) encontradas foram: grupo 1) 20,54( $\pm 4,0)$; G2) 20,78( $\pm 3,8)$; G3) 20,29( $\pm 3,3)$; G4) 20,97( $\pm 2,8)$; G5) 20,03( $\pm 2,9)$ e G6) 14,73( $\pm 3,5)$. teste de Tukey $(p>0,05)$ demonstrou que não houve diferenças estatisticamente significantes entre os grupos que receberam aplicação de agente adesivo, independentemente do tratamento de superfície executado. As médias de resistência à tração desses grupos foram significativamente maiores do que a do grupo controle.

HISAMATSU; ATSUTA; MATSUMURA ${ }^{44}$, em 2002, examinaram o efeito da aplicação de agentes silanos (Porcelain Liner M ou Silicer) e de sistemas adesivos (Dentacolor opaker liquid e new metacolor photo opaque liquid) no procedimento de reparo de uma resina laboratorial (Dentacolor DA). Segundo os autores os maiores valores de resistência ao cisalhamento foram obtidos com a combinação da aplicação dos agentes silanizadores e posterior inserção dos sistemas adesivos. Para os mesmos torna-se sempre necessária o uso de um adesivo após a aplicação do agente silanizador quando realizamos reparos de compósitos.

Em 2002, HAGGE; LINDEMUTH verificaram a resistência de união de reparos de resina a base de bis-acrilato. Os espécimes foram divididos em seis grupos sendo que em três destes grupos após o jateamento superficial aplicourse um sistema adesivo. Na outra metade o único tratamento de superfície empregado foi o 
jateamento. Os autores concluíram que o grupo onde apenas o jateamento foi empregado obteve estatisticamente os melhores valores de resistência ao cisalhamento.

GORDAN et al ${ }^{40}$, em 2003, avaliaram se as faculdades de odontologia da américa do norte preconizam a realização de reparos de restaurações de resina composta. Os autores enviaram um questionário contendo quinze perguntas para 64 faculdades de odontologia dos Estados Unidos, Canadá e Porto Rico. 52 (81\%) das 64 faculdades responderam o questionário. 37 (71\%) das que responderam consideram o reparo de compósitos como uma alternativa viável e inclusive preconizam entre os seus discentes o referido procedimento. Para estas faculdades a realização de reparo em resina composta torna-se viável principalmente pela preservação da estrutura dentária e a ocorrência de menor injúria pulpar. 
3. PROPOSIÇÃO 


\section{PROPOSIÇÃO}

Diante do amplo emprego das resinas compostas atualmente e a viabilidade e importância da utilização dos procedimentos de reparos em restaurações que envolvem o material estético acima citado, além do advento das mais variadas técnicas e materiais voltados para tal propósito, esta pesquisa propõe-se a avaliar:

$\checkmark$ A resistência à tração de espécimes com e sem reparo confeccionados com uma resina composta híbrida;

$\checkmark$ a influência do tipo de tratamento superficial de uma resina composta sobre a resistência à tração de reparos realizados após armazenamento durante 18 meses em água deionizada a $37^{\circ} \mathrm{C}$. 
4. MATERIAL E MÉTODOS 


\section{MATERIAL E MÉTODOS}

\section{1-) Considerações Iniciais:}

Os diversos materiais utilizados no presente estudo foram manipulados de acordo com as especificações nf $^{\text {s }} 1^{4}$ e $27^{3}$ da A.D.A., em ambiente com temperatura entre $23 \pm 2^{0} \mathrm{C}$ regulada por meio de um condicionador de ar (Admiral Royal Springer Refrigeração S. A., Brasil). A umidade relativa do ar permaneceu no intervalo de $50 \pm 10 \%$, sendo ajustada pelo uso de dois desumidificadores (OASIS, modelo 300, fabricado por EBCO Manufacturing Company, Columbus - Ohio - USA) e acompanhada por meio de um higrômetro (FISHER - França). Todo experimento foi realizado por um único operador.

Os materiais empregados na presente pesquisa, bem como seus fabricantes e respectivas composições, estão listados na Tabela 1. 
Tabela 1 - Materiais utilizados no estudo, fabricantes, composições e números dos lotes.

\begin{tabular}{|c|c|c|c|}
\hline $\begin{array}{c}\text { Marca } \\
\text { Comercial }\end{array}$ & Fabricante & Composição & $\begin{array}{l}\text { N. de } \\
\text { Lote }\end{array}$ \\
\hline $\begin{array}{c}\text { Resina } \\
\text { Composta } \\
\text { Tetric Ceram }\end{array}$ & VIVADENT & $\begin{array}{l}\text { Bis-GMA, TEGDMA, UEDMA, vidro de } \\
\text { bário, trifluoreto de itérbio, vidro de } \\
\text { fluorsilicato de alumínio e bário, dióxido } \\
\text { de silício altamente disperso, óxidos } \\
\text { mistos esferoidais, catalisadores, } \\
\text { estabilizadores e pigmentos }\end{array}$ & $\begin{array}{l}\text { C32630 } \\
\text { (cor A1) } \\
\text { C32080 } \\
\text { (cor C3) }\end{array}$ \\
\hline $\begin{array}{l}\text { Adesivo } \\
\text { Heliobond }\end{array}$ & VIVADENT & Bis-GMA e TEGDMA & $\mathrm{C} 09716$ \\
\hline Monobond - S & VIVADENT & $\begin{array}{c}\text { 3-Metacriloxipropil-trimetoxisiláno, } \\
\text { Solução de Âgua/Etanol com Ácido } \\
\text { Acético }(\mathrm{pH}=4)\end{array}$ & $\overline{C 12012}$ \\
\hline $\begin{array}{l}\text { Condicionador } \\
\text { de Porcelanas }\end{array}$ & Dentsply & Ácido Hidrofluorídrico a 10\% & 32889 \\
\hline
\end{tabular}

A resina composta Tetric Ceram (VIVADENT, Schaan - Liechtenstein) foi utilizada tanto para a obtenção da porção a ser reparada quanto para o seu reparo. Tetric Ceram (VIVADENT, Schaan - Liechtenstein) é um compósito híbrido de partículas pequenas, radiopacas e fotopolimerizável para restaurações dentais anteriores, posteriores e para reparo de próteses metalocerâmica, metalo-plástica, restaurações indiretas de cerâmica e compósito. A matriz orgânica é composta por Bis-GMA, TEGDMA, UEDMA (20,2\% em peso). A matriz inorgânica é constituída por vidro de bário, trifluoreto de itérbio, vidro de flúorsilicato de alumínio e bário, dióxido de silício altamente disperso, óxidos mistos esferoidais $(79 \%$ em peso). Além disto, Tetric Ceram contém catalisadores, estabilizadores e pigmentos $(0,8 \%$ em peso). $O$ conteúdo total de 
carga inorgânica é de $80 \%$ em peso e $60 \%$ em volume. O tamanho das partículas está situado entre 0,04 e $3 \mu \mathrm{m}$, com tamanho médio de 0,7 $\mu \mathrm{m}$.

\section{2-) Dispositivo utilizado para confecção dos corpos-de-prova:}

O dispositivo empregado para a obtenção dos espécimes envolvidos neste estudo foi confeccionado em teflon. Este material foi empregado porque o mesmo não adere aos compósitos de maneira geral, facilitando o manuseio e a remoção dos corpos-de-prova. O referido dispositivo nada mais é que uma matriz de teflon bipartido e quadrangular de $16 \mathrm{~mm} \times 16 \mathrm{~mm}$, possuindo em sua metade uma demarcação (figura 1). A presença desta demarcação permitiu padronizar as dimensões dos espécimes a serem reparados com a futura porção de resina composta inserida após os tratamentos superficiais. 


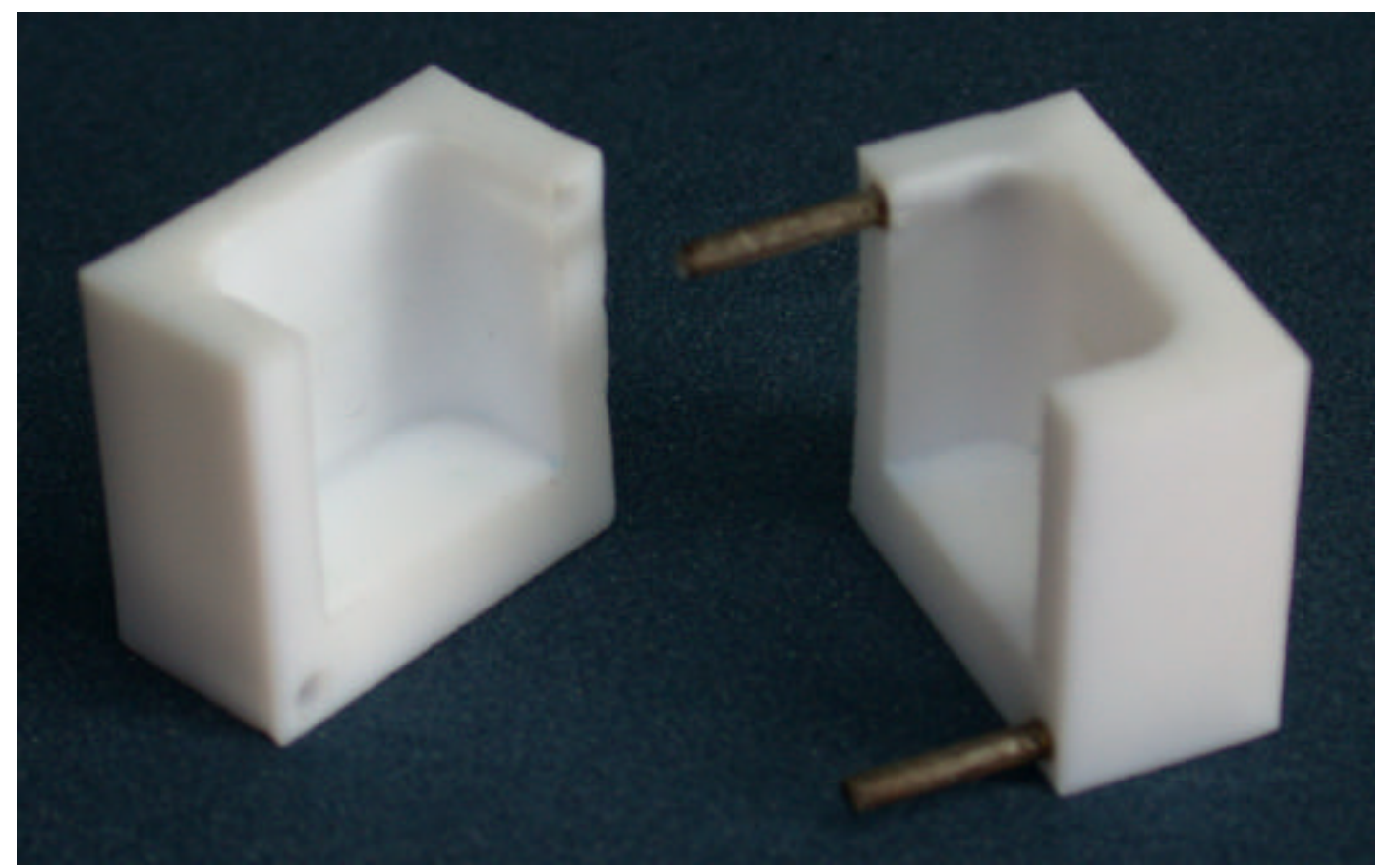

Figura 1: Matriz de teflon bipartido utilizado para confecção das restaurações de resina composta.

\section{3-) Obtenção das restaurações de resina composta a serem reparadas:}

A partir do emprego da matriz de teflon bipartida foram confeccionados blocos de resina composta Tetric Ceram (VIVADENT, Schaan - Liechtenstein) da cor A1 com $8 \mathrm{~mm}$ de altura (metade da altura do dispositivo). Para tal propósito as bisnagas de resina composta foram retiradas do refrigerador alguns minutos antes do uso para que atingissem a temperatura ambiente. Com o auxílio de uma espátula para inserção e condensação de resina composta, Tactile Tone GTX (Thompson Dental Mfg Co. - USA) incrementos do compósito foram inseridos e condensados de encontro às paredes do dispositivo, não ultrapassando $2 \mathrm{~mm}$ de espessura. Tornourse necessária a inserção de 
aproximadamente 4 incrementos para atingir metade da altura da matriz de teflon. A fonte polimerizadora (Optilux Demetron modelo VCL 403, fabricado pela Demetron Research Corp.- Danruby, CT - USA, com potência de $490 \mathrm{~mW} / \mathrm{cm}^{2}$ ) foi colocada em duas regiões distintas de cada incremento, nas duas extremidades, e acionadas durante 40 segundos em cada localidade. As amostras depois de confeccionadas eram removidas da matriz de teflon e o fotoativador era novamente acionado por mais 60 segundos. Deste modo, as áreas mais afastadas da luz, como as laterais e inferior do espécime, tiveram sua polimerização assegurada. Os espécimes assim obtidos permaneceram armazenados em água deionizada a temperatura de $37^{\circ} \mathrm{C}$ por sete dias, antes de receberem o tratamento superficial de destino. Para cada grupo deste estudo foi confeccionado um bloco de resina composta.

Antes da confecção de cada restauração de resina composta a ser reparada, o desempenho do aparelho fotoativador era monitorado utilizando-se um radiômetro (Demetron model 100, fabricado pela Demetron Research Corp. - Danruby, CT - USA).

\section{4-) Obtenção do grupo controle:}

Um grupo específico, formado por corpos-de-prova que não sofreram nenhum tipo de reparo, foi elaborado como controle (grupo IX) seguindo os mesmos passos descritos no item 4.3. Este grupo tinha como finalidade determinar a resistência coesiva da resina composta Tetric Ceram depois de decorrido o mesmo tempo de armazenamento dos demais grupos envolvidos 
nesta pesquisa, procurando desta forma tecer uma comparação com os valores obtidos pelos grupos de restaurações que passaram pelo procedimento reparador.

\section{5-) Tratamentos das superfícies para reparo:}

A distribuição dos grupos e seus respectivos tratamentos superficiais estão listados na Tabela 2. As restaurações de resina composta a serem reparadas, após permanecerem armazenadas por sete dias nas condições descritas anteriormente, tiveram suas superfícies planificadas (A planificação superficial tornou-se necessária para padronizar o emprego dos tratamentos) em uma politriz (modelo DP-92, fabricada pela Panambra Industrial e Técnica S.A. São Paulo - S.P.) com lixas de carbeto de silício (3M, São Paulo - Brasil) e granulação decrescente, com as numerações de 400 e 600 respectivamente. Para tal procedimento a politriz desenvolveu uma velocidade de 300 rotações por minuto, sob refrigeração abundante de água. Depois de intensa lavagem com jatos de ar/água, provenientes de uma seringa tríplice, durante 15 segundos as restaurações a serem reparadas foram secas com jatos de ar, para serem então divididas aleatoriamente em 8 grupos.

As restaurações de resina composta dos Grupos I e II tiveram suas superfícies polidas tratadas com ácido fosfórico em gel a 37\% (VIGODENT S.A. Indústria e Comércio, Rio de Janeiro, Brasil) durante 30 segundos, seguido de lavagem com jatos de água por 60 segundos e secagem com cones de papel absorvente (Lote: 27394, Dentsply Indústria e Comércio Ltda. Petrópolis - R.J.). 
As restaurações dos grupos III e IV foram tratadas com ácido hidrofluorídrico a 10\% (Dentsply Indústria e Comércio Ltda. Petrópolis - R.J.) na forma de gel durante 60 segundos, seguido de lavagem por 2 minutos e secagem com cones de papel absorvente. As superfícies dos grupos $\mathrm{V}$ e $\mathrm{VI}$ foram tratadas com um jato de óxido de alumínio de $50 \mu \mathrm{m}$ (Micro Jato VH com bico removível, VH Equipamentos Médico-Odontológicos e Acessórios - Araraquara - S.P.) durante 10 segundos, a uma distância aproximada de dois centímetros da superfície da restauração a ser reparada. Logo após as superfícies foram lavadas por 20 segundos e secadas com cones de papel absorvente.

Após os referidos tratamentos de superfície e antes da execução dos reparos, cada grupo recebeu diferentes tratamentos químicos para adesão. A superfície da restauração de resina composta referente ao grupo I teve sua superfície pincelada com uma camada do agente silanizador Monobond - S (VIVADENT, Schaan - Liechtenstein) que ficou atuando por 60 segundos. Findado este tempo foram utilizados cones de papel absorvente para secar a superfície. Em seguida uma fina camada do adesivo Heliobond (VIVADENT, Schaan - Liechtenstein) foi aplicada e fotoativada por 10 segundos (Optilux Demetron modelo VCL 403, fabricado pela Demetron Research Corp.- Danruby, CT - USA, com potência de $490 \mathrm{~mW} / \mathrm{cm}^{2}$ ). O grupo II, após o condicionamento com ácido fosfórico, recebeu a aplicação direta do sistema adesivo Heliobond nos moldes do grupo I. Já a superfície da restauração do grupo III, após a utilização do ácido hidrofluorídrico, recebeu a aplicação do Monobond - S que ficou atuando por 60 segundos, em seguida foi realizada a secagem com cones 
de papel absorvente. Logo após o adesivo Heliobond foi pincelado na superfície seca, sendo polimerizado por 10 segundos. A restauração do grupo IV, depois da aplicação e lavagem do ácido hidrofluorídrico e secagem de sua superfície, recebeu a aplicação do adesivo Heliobond de maneira semelhante ao grupo III. Posteriormente a utilização do jateamento, a superfície da restauração de resina composta do grupo $\mathrm{V}$ recebeu a aplicação do agente silano Monobond $-\mathrm{S}$ que atuou por 60 segundos. Findado este tempo foi realizada a secagem da superfície (com auxílio de cones de papel absorvente) e em seguida aplicou-se o adesivo Heliobond que em seguida foi polimerizado por 10 segundos. Para o grupo VI, posteriormente ao jateamento, pincelou-se somente o sistema adesivo Heliobond, que foi polimerizado por 10 segundos.

Os grupos VII e VIII não passaram por nenhum tipo de condicionamento ácido ou jateamento prévio. A superfície da restauração de resina composta do grupo VII recebeu uma fina camada do agente silanizador Monobond - S que ficou atuando por 60 segundos. Logo após foi feita a secagem desta superfície, através do emprego de cones de papel absorvente, e a aplicação do agente adesivo Heliobond que foi polimerizado por 10 segundos. Já o grupo VIII foi tratado somente com a aplicação do sistema adesivo Heliobond, sendo também polimerizado por 10 segundos. 
Tabela 2 - Distribuição dos grupos com seus respectivos tratamentos e materiais empregados.

\begin{tabular}{|c|c|c|c|c|}
\hline Grupos & $\begin{array}{c}\text { Resina da } \\
\text { restauração } \\
\text { original }\end{array}$ & Preparo da superfície & Sistemas adesivos & $\begin{array}{c}\text { Resina } \\
\text { de } \\
\text { reparo }\end{array}$ \\
\hline 1 & \multirow{9}{*}{ Tetric Ceram } & ácido fosfórico a 37\% & silano + adesivo & \multirow{9}{*}{$\begin{array}{l}\text { Tetric } \\
\text { Ceram }\end{array}$} \\
\hline II & & ácido fosfórico a 37\% & adesivo & \\
\hline III & & ácido hidrofluorídrico a 10\% & silano + adesivo & \\
\hline IV & & ácido hidrofluorídrico a $10 \%$ & adesivo & \\
\hline V & & Jateamento $\mathrm{com} \mathrm{Al}_{2} \mathrm{O}_{3}$ & silano + adesivo & \\
\hline $\mathrm{VI}$ & & Jateamento com $\mathrm{Al}_{2} \mathrm{O}_{3}$ & adesivo & \\
\hline VII & & --------- & silano + adesivo & \\
\hline VIII & & ------- & adesivo & \\
\hline IX & & ---------- & ב------- & \\
\hline
\end{tabular}

\section{6-) Obtenção das restaurações de resina composta reparadas:}

As restaurações originais, após receberem os respectivos preparos superficiais, retornaram à matriz de teflon bipartido. A resina correspondente ao reparo Tetric Ceram (VIVADENT, Schaan - Liechtenstein) foi condensada e fotoativada no espaço restante da matriz $(8 \mathrm{~mm})$ seguindo os mesmos tópicos do item 4.3 (figura 2). Para facilitar a visualização da interface, a resina de reparo foi utilizada em outra cor (cor C3). Os corpos-de-prova obtidos permaneceram armazenados em água deionizada a $37^{\circ} \mathrm{C}$ por 18 meses, até serem preparados e submetidos ao teste de micro-tração. 


\section{7-) Obtenção dos espécimes para o teste de micro-tração:}

Após o armazenamento, os espécimes foram fixados, com godiva, paralelamente ao seu longo eixo em um suporte metálico, para serem adaptados à máquina de cortes seriados Isomet, Buehler, Lake Bluff, IL, USA (figura 3). Utilizando um disco de diamante girando em baixa velocidade com constante irrigação, foram feitos cortes seriados paralelos ao longo eixo do espécime, em espessuras de aproximadamente 0,6 mm (figuras 4 e 5). No final, a base do espécime foi seccionada perpendicularmente ao seu longo eixo, obtendo-se vários espécimes em forma de "palitos" (figura 6).

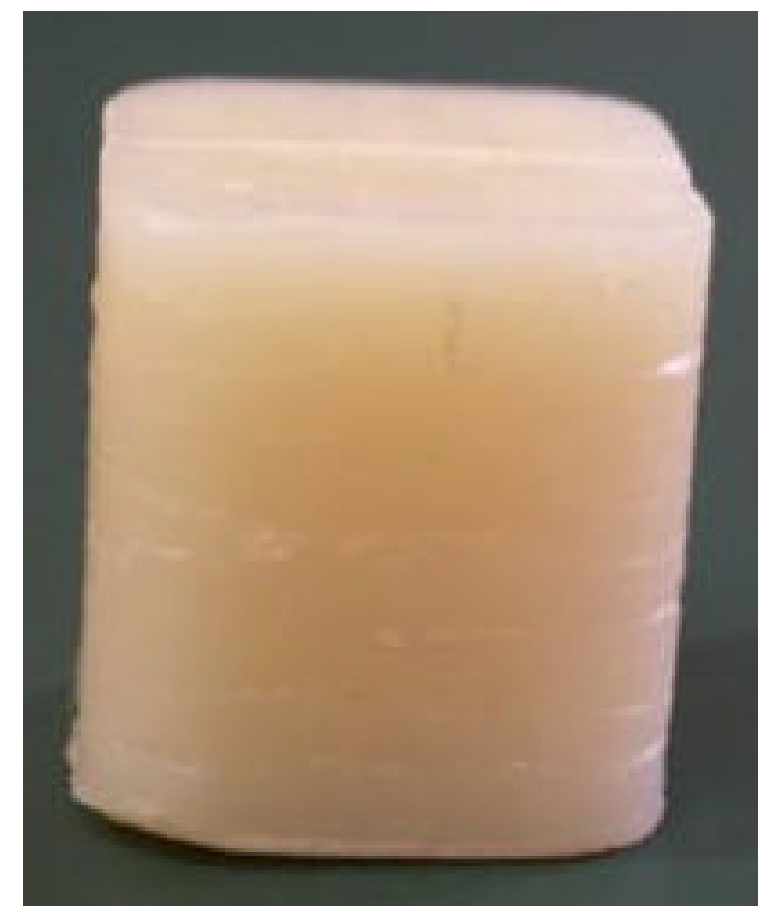

Figura 2: Restauração de resina composta. 


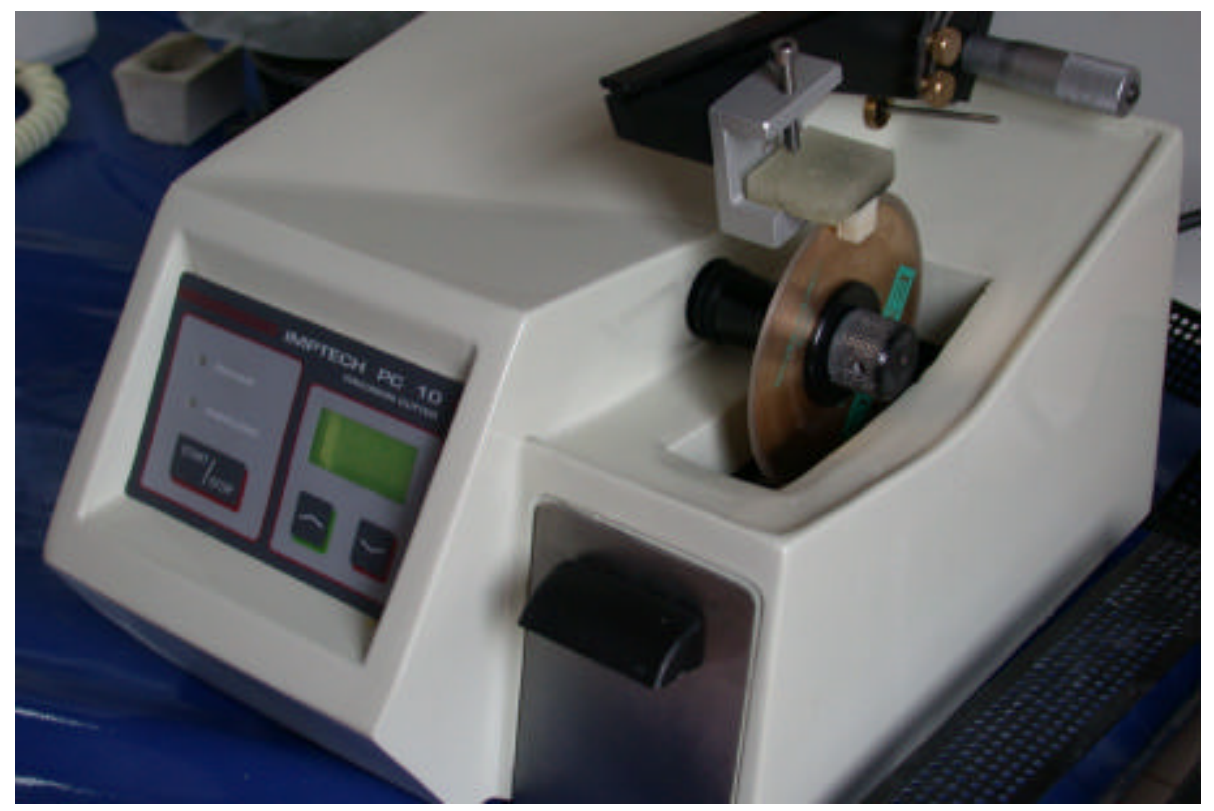

Figura 3: Restauração de resina composta adaptada àmáquina de cortes seriados.

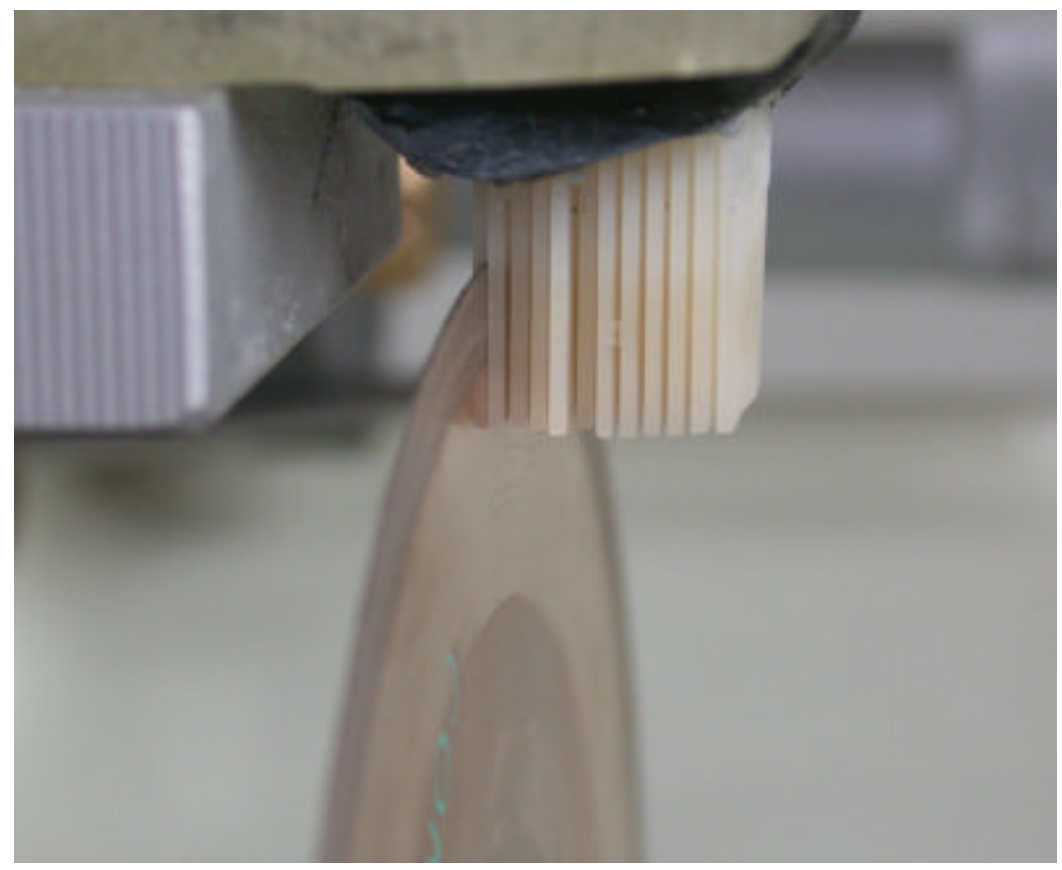

Figura 4: Visão dos cortes seriados paralelos ao longo eixo do espécime. 


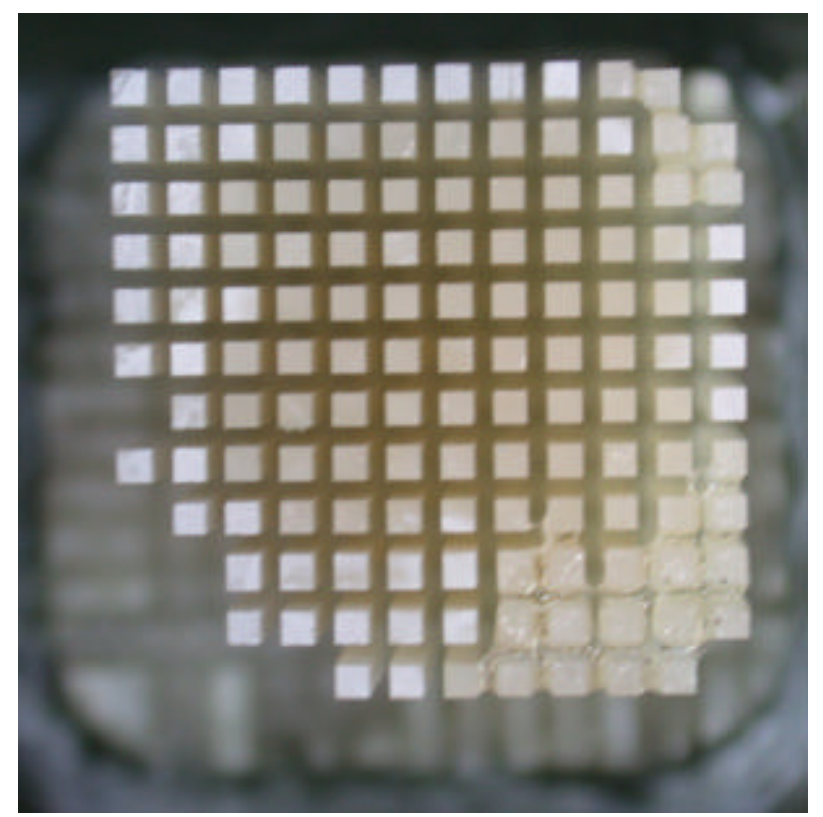

Figura 5: Visão superior dos cortes seriados paralelos ao longo eixo do espécime.

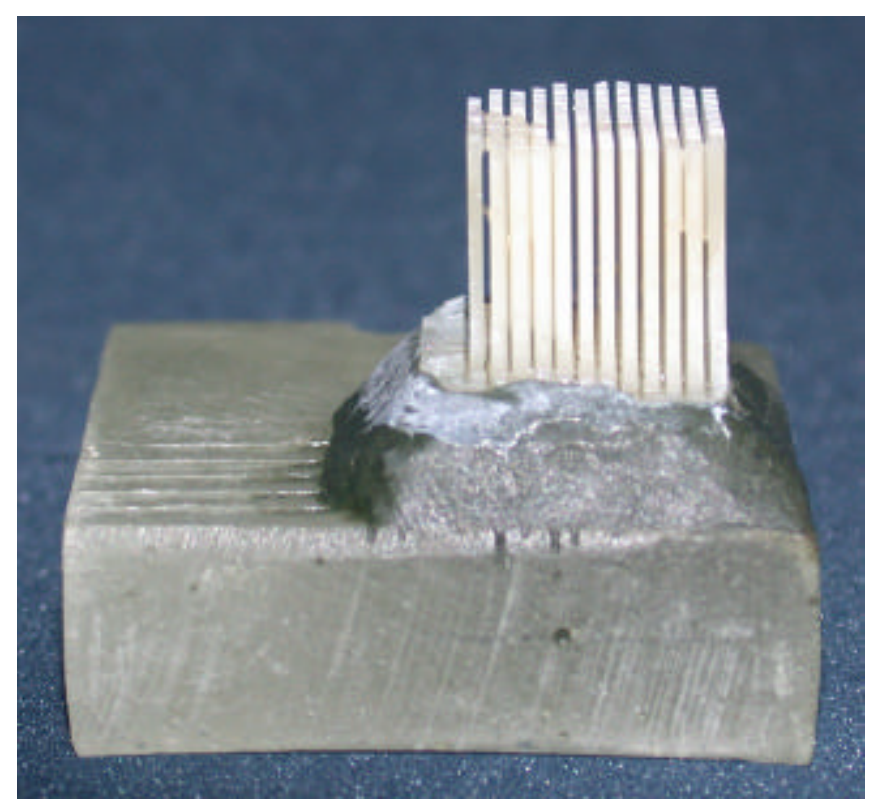

Figura 6: Visão frontal dos "palitos" de resina composta fixados à base de resina epóxica com godiva. 
Os espécimes antes de serem submetidos à força de tração, foram avaliados sob a luz de um microscópio com sete vezes de aumento (Stereo Zoom 7, Bausch \& Lomb Incorporated, Rochester, NY - USA) para verificar se na área de adesão não havia falhas no processo adesivo (presença de bolha). Os espécimes foram individualmente afixados ao dispositivo de micro-tração (DL $500 \mathrm{BF}$ - EMIC - equipamentos e sistemas de ensaio LTDA), com um adesivo a base de cianoacrilato (Zapit, DVA, Yorba Linda, CA - USA) pelas suas extremidades, de modo a posicionar a área de adesão perpendicular ao longo eixo da força de tração (figuras 7 e 8). Os testes foram realizados com uma velocidade de $0,5 \mathrm{~mm} / \mathrm{min}$.

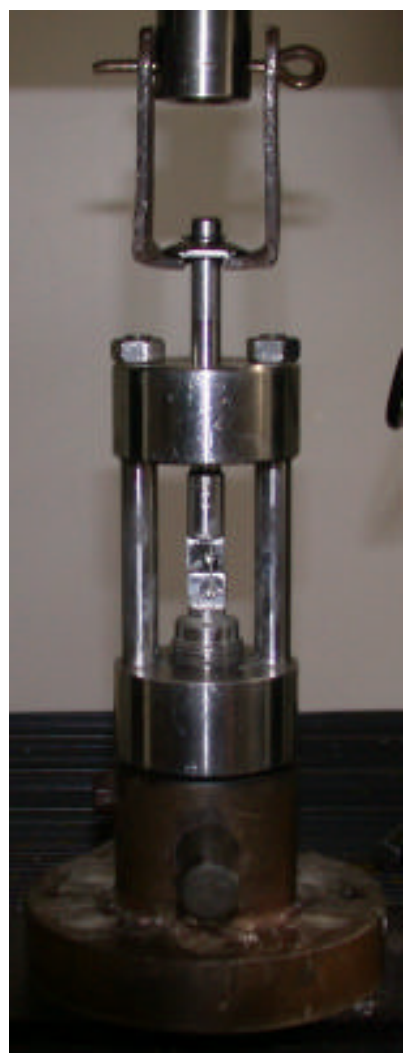

Figura 7: Visão geral do dispositivo de micro-tração. 


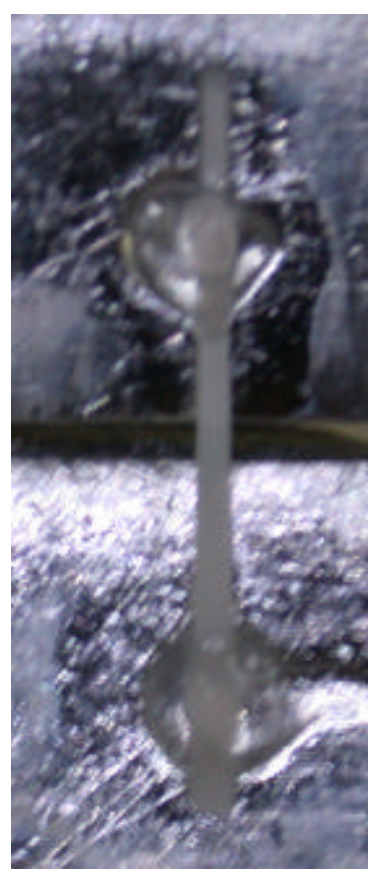

Figura 8: Aspecto do espécime afixado no dispositivo de micro-tração.

Durante o teste, todo evento foi monitorado por um programa de computador que apresentava na tela um gráfico representando a carga em função do deslocamento. No momento da fratura (figura 9), o movimento era imediatamente cessado e os dados coletados e impressos para posterior cálculo e análise.

Após o teste, as duas porções fraturadas foram removidas e a área transversal correspondente à fratura foi medida, utilizando-se um paquímetro universal com leitura digital eletrônica (Sylvae Ultra-Cal II, Fowler Co., Inc., Newton, MA - USA) com precisão de 0,1 mm. O valor da área foi transformado 
em $\mathrm{cm}^{2}$ e o valor da carga em $\mathrm{Kg}$. Os valores finais de resistência adesiva foram calculados e expressos em MPa.

O modo de fratura da interface adesiva foi avaliado em microscopia ótica (Stereo Zoom 4, Bausch \& Lomb Incorporated, Rochester, NY - USA) com quarenta vezes de aumento e classificada em três tipos: adesiva, coesiva ou mista. Todos os espécimes apresentaram fraturas adesivas, excetuando-se o grupo controle onde foi observada a resistência coesiva da resina composta empregada no presente trabalho. 


\section{RESULTADOS}




\section{5 . RESULTADOS:}

Os valores individuais de resistência adesiva e área de adesão de todos os espécimes testados neste estudo estão representados no capítulo "ANEXOS" em forma de tabelas.

A maior média de todos os grupos $(80,91 \pm 0,93 \mathrm{MPa})$ foi obtida pelo grupo IX (controle), onde foi aferida a resistência coesiva da resina composta utilizada neste experimento (tabela 3).

Tabela 3: Valores individuais, médias e desvios padrões da resistência à microtração de espécimes reparados e não reparados após 18 meses (MPa).

\begin{tabular}{c|c|c|c|c|c|c|c|c|c}
\hline Espécime & $\begin{array}{c}\text { Grupo } \\
\text { I }\end{array}$ & $\begin{array}{c}\text { Grupo } \\
\text { II }\end{array}$ & $\begin{array}{c}\text { Grupo } \\
\text { III }\end{array}$ & $\begin{array}{c}\text { Grupo } \\
\text { N }\end{array}$ & $\begin{array}{c}\text { Grupo } \\
\text { V }\end{array}$ & $\begin{array}{c}\text { Grupo } \\
\text { VI }\end{array}$ & $\begin{array}{c}\text { Grupo } \\
\text { VII }\end{array}$ & $\begin{array}{c}\text { Grupo } \\
\text { VIII }\end{array}$ & $\begin{array}{c}\text { Grupo } \\
\text { I }\end{array}$ \\
\hline 1 & 48.27 & 63.28 & 30.00 & 28.17 & 46.30 & 47,97 & 63.00 & 46,00 & 81.42 \\
\hline 2 & 47.25 & 64.91 & 27.81 & 27.53 & 50.00 & 52,43 & 61.00 & 48,00 & 80.70 \\
\hline 3 & 49.57 & 64.29 & 33.62 & 29.12 & 46.14 & 52,24 & 59.22 & 53,76 & 80.10 \\
\hline 4 & 46.00 & 61.74 & 30.26 & 23.12 & 48.00 & 43,46 & 61.10 & 45,16 & 80.21 \\
\hline 5 & 47.00 & 68.61 & 24.07 & 23.84 & 46.30 & 43,46 & 64.55 & 41,43 & 80.48 \\
\hline 6 & 45.58 & 61.48 & 26.83 & 29.00 & 47.00 & 52,14 & 61.54 & 49,64 & 80.00 \\
\hline 7 & 49.28 & 61.00 & 24.79 & 25.80 & 47.38 & 48,53 & 58.27 & 47,38 & 81.00 \\
\hline 8 & 51.86 & 61.05 & 27.00 & 30.00 & 47.93 & 51,53 & 59.15 & 53,86 & 81.00 \\
\hline 9 & 45.98 & 65.90 & 28.67 & 27.00 & 45.29 & 49,21 & 61.34 & 53,31 & 80.31 \\
\hline 10 & 48.23 & 63.18 & 28.35 & 26.31 & 46.63 & 52,71 & 62.30 & 52,88 & 82.57 \\
\hline 11 & 48.82 & 62.60 & 26.82 & 24.27 & 46.40 & 52,92 & 61.44 & 52,73 & 80.00 \\
\hline 12 & 51.54 & 63.28 & 31.79 & 28.71 & 47.00 & 49,27 & 63.00 & 52,34 & 81.81 \\
\hline 13 & 47.38 & 63.83 & 28.36 & 26.12 & 49.28 & 50,39 & 60.53 & 52,43 & 79.46 \\
\hline 14 & 48.30 & 62.16 & 28.07 & 26.91 & 49.74 & 45,78 & 61.48 & 44,00 & 82.00 \\
\hline 15 & 50.82 & 61.54 & 27.60 & 26.41 & 44.57 & 52,48 & 60.76 & 47,22 & 81.36 \\
\hline 16 & 46.50 & 62.30 & 26.70 & 26.64 & 49.64 & 47,71 & 63.44 & 47,00 & 79.20 \\
\hline 17 & 45.85 & 62.23 & 29.24 & 26.35 & 51.63 & 52,63 & 61.35 & 54,25 & 82.01 \\
\hline 18 & 46.11 & 64.40 & 26.46 & 30.00 & 51.21 & 49,21 & 60.00 & 43,16 & 80.83 \\
\hline 19 & 46.37 & 67.66 & 28.97 & 28.07 & 51.93 & 49,61 & 61.25 & 44,05 & 81.65 \\
\hline 20 & 50.00 & 63.63 & 26.00 & 25.10 & 48.00 & 51,37 & 61.54 & 48,00 & 82.04 \\
\hline Média & 48.04 & 63.45 & 28.07 & 26.92 & 48.02 & 49.75 & 61.31 & 48.83 & 80.91 \\
\hline DP & 1.96 & 2.07 & 2.24 & 1.94 & 2.12 & 2.94 & 1.50 & 4.10 & 0.93 \\
\hline & & & & & & & & &
\end{tabular}


A análise de variância realizada entre o grupo controle e os grupos experimentais revelou a presença de diferenças significantes como mostra a tabela 4. No teste de comparações individuais, estas diferenças foram localizadas de maneira específica entre o grupo controle e todos os grupos experimentais (tabela 5).

Tabela 4: Resultado da ANOVA entre o grupo controle e os experimentais.

\begin{tabular}{cccccc}
\hline $\begin{array}{c}\text { Fonte de } \\
\text { Variação }\end{array}$ & $\begin{array}{c}\text { Soma de } \\
\text { quadrados }\end{array}$ & $\begin{array}{c}\text { Graus de } \\
\text { liberdade }\end{array}$ & $\begin{array}{c}\text { Quadrado } \\
\text { Médio }\end{array}$ & "F" & Probab. \\
\hline Entre grupos & 45675.4271 & 8 & 5709.4284 & 1024.5655 & $3.6 \mathrm{E}-140$ \\
Resíduo & 952.9037 & 171 & 5.5725 & & \\
\hline Total & 46628.3308 & 179 & & & \\
\hline
\end{tabular}

Significante a $5 \%$

Tabela 5: Resultados do teste de comparações individuais (Tukey) entre grupos controle e experimentais em nível de $5 \%$ de significância $(p<0,05)$.

\begin{tabular}{llccc}
\hline \multicolumn{2}{c}{ Comparação } & Diferença & Valor crítico & Interpretação \\
\hline Controle & X Grupo I & 32.872 & 2.315 & $*$ \\
Controle & X Grupo II & 17.454 & 2.315 & $*$ \\
Controle & X Grupo III & 52.837 & 2.315 & $*$ \\
Controle & X Grupo IV & 53.984 & 2.315 & $*$ \\
Controle & X Grupo V & 32.889 & 2.315 & $*$ \\
Controle & X Grupo VI & 31.155 & 2.315 & $*$ \\
Controle & X Grupo VII & 19.594 & 2.315 & $*$ \\
Controle & X Grupo VIII & 32.077 & 2.315 & $*$ \\
\hline
\end{tabular}

* Diferença estatisticamente significante

Nota-se pela tabela 5 que o grupo controle apresentou resultados estatisticamente superiores em relação aos grupos experimentais. 
A análise de variância dos grupos experimentais revelou diferenças estatisticamentes significantes entre as médias dos valores de resistência à tração (tabela 6). As comparações múltiplas entre os grupos de espécimes reparados com diferentes tratamentos e submetidos a testes de resistência à tração estão listadas na tabela 7.

Tabela 6: Resultados da análise de variância a um critério (ANOVA) aplicada aos resultados obtidos com espécimes reparados após 18 meses de armazenagem e submetidos ao teste de resistência à micro-tração.

\begin{tabular}{cccccc}
\hline $\begin{array}{c}\text { Fonte de } \\
\text { Variação }\end{array}$ & $\begin{array}{c}\text { Soma de } \\
\text { quadrados }\end{array}$ & $\begin{array}{c}\text { Graus de } \\
\text { liberdade }\end{array}$ & $\begin{array}{c}\text { Quadrado } \\
\text { Médio }\end{array}$ & "F" & Probabilidade \\
\hline Entre grupos & 24993.9444 & 7 & 3570.5635 & 579.5414 & .00000000 \\
Resíduo & 936.4744 & 152 & 6.1610 & & \\
Total & 25930.4188 & 159 & & & \\
\hline
\end{tabular}

Significante a $5 \%$.

Tabela 7: Descrição dos grupos e médias de resistência à tração dos espécimes reparados após período de 18 meses de armazenamento.

\begin{tabular}{cccc}
\hline Grupos & Tratamentos & n. de amostras & Média + DP (MPa) \\
\hline II & $\mathrm{H}_{3} \mathrm{PO}_{4}+$ adesivo & 20 & $63,45 \pm 2,07$ \\
VII & silano + adesivo & 20 & $61,31 \pm 1,50$ \\
VI & $\mathrm{Al}_{2} \mathrm{O}_{3}+$ adesivo & 20 & $49,75 \pm 2,94$ \\
VIII & Adesivo & 20 & $48,83 \pm 4,10$ \\
I & $\mathrm{H}_{3} \mathrm{PO}_{4}+$ silano + adesivo & 20 & $48,04 \pm 1,96$ \\
V & $\mathrm{Al}_{2} \mathrm{O}_{3}+$ silano + adesivo & 20 & $48,02 \pm 2,12$ \\
III & $\mathrm{HF}+$ silano + adesivo & 20 & $28,07 \pm 2,24$ \\
IV & $\mathrm{HF}+$ adesivo & 20 & $26,92 \pm 1,94$ \\
\hline
\end{tabular}

Os valores conectados por linhas verticais são estatisticamente semelhantes. ( $P>0,005)$. 
De acordo com os dados expressos na tabela 7 nota-se que todos os grupos que foram submetidos ao jateamento com $\mathrm{Al}_{2} \mathrm{O}_{3}$ (Grupos $\mathrm{V}$ e $\mathrm{VI}$ ) apresentaram resultados médios de resistência semelhantes entre si. Os reparos obtidos com o preparo da superfície com ácido hidrofluorídrico e aplicação de silano e adesivo (Grupo III) e ácido hidrofluorídrico seguido da aplicação de adesivo (Grupo IV) resultaram em valores estatisticamente significante mais baixos de resistência à tração, sendo 28,07 e 26,92 MPa, respectivamente.

Os Grupos II ( $\mathrm{H}_{3} \mathrm{PO}_{4}$ + adesivo) e VII (silano + adesivo) apresentaram significantemente os mais altos valores de resistência à tração em relação aos demais grupos reparados, porém não demonstraram diferenças significantes entre si.

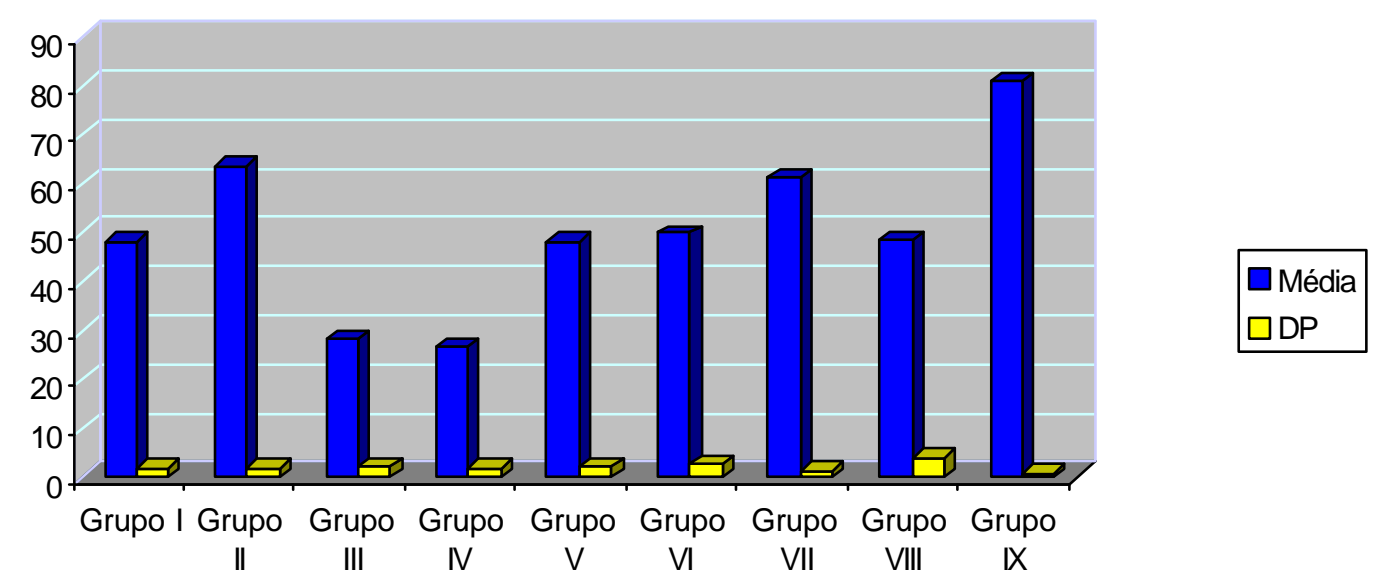

Figura 10: Gráfico representativo da distribuição das médias de resistência à tração e desvio padrão dos grupos controle e de espécimes reparados após período de 18 meses de armazenamento (MPa). 
6. DISCUSSÃO 


\section{DISCUSSÃO}

\subsection{Considerações Iniciais:}

Desde o seu surgimento as resinas compostas vêm sendo utilizadas em dentes posteriores e exaustivamente avaliadas. As primeiras resinas compostas (macropartículas) não apresentavam bom desempenho clínico, com níveis de desgaste elevados (100 a $150 \mu \mathrm{m} / \mathrm{ano})^{67}$

De acordo com a ADA. as resinas compostas não deveriam apresentar desgastes superiores a $125 \mu \mathrm{m}$ após 2 anos e $174 \mu \mathrm{m}$ após 4 anos. Segundo BUSATO et al. ${ }^{18}$ o desgaste da resina composta é padronizado, podendo ser em torno de 10 a $15 \mu \mathrm{m}$ no primeiro ano, o qual tende a aumentar com o tempo devido ao aparecimento do fenômeno de degradação química.

Vários fatores são determinantes no processo de desgaste e/ou fratura das restaurações de resinas compostas tais como: tamanho e distribuição das partículas; dureza das partículas; desintegração química; rugosidade da superfície da restauração; localização do dente na arcada dentária; o local e a dimensão dos contatos oclusais; a amplitude da restauração no sentido vestíbulo-lingual; a técnica de acabamento e polimento empregada; o grau de polimerização da resina composta e a ocorrência de porosidade no interior do material restaurador.

Diante do exposto a substituição parcial ou reparo das restaurações que sofreram desgastes e/ou fratura, por sua vez, é uma solução considerável, principalmente naqueles casos onde a maior parte da restauração pode ser considerada satisfatória clínica e radiograficamente. 
O material envolvido, a expectativa de longevidade da restauração a ser reparada e as condições estéticas são fatores a serem considerados quando o profissional elege o reparo da restauração como primeira opção de tratamento.

A presença de cárie secundária e a quantidade de material a ser removido são condições que devem ser observadas para indicação do tratamento correto, bem como a análise da localização, tamanho e extensão do defeito.

Dentre as vantagens do reparo, quando comparadas à substituição total das restaurações, pode-se citar o menor desgaste de estrutura dentária sadia, e por isto menor enfraquecimento do remanescente dentário e menores danos pulpares. Além disso o reparo poderá resolver o problema e garantir a longevidade da restauração num tempo clínico menor e com custo mais baixo.

\subsection{Da metodologia proposta:}

O conhecimento das propriedades dos materiais em Odontologia é imprescindível na seleção e indicação do mais adequado para determinada situação. Por serem os materiais restauradores muito solicitados mecanicamente e expostos a tensões complexas, grande parte das pesquisas está direcionada para o estudo de parâmetros que avaliam está resistência.

ANUSAVICE ${ }^{6}$ conceitua a resistência como sendo a carga necessária para causar a fratura ou uma quantidade específica de deformação permanente podendo ser descrita por uma ou mais das seguintes propriedades: limite de proporcionalidade, limite de elasticidade, limite de escoamento, resistência máxima à tração, compressão, ao cisalhamento e à flexão. 
Os testes laboratoriais permitem obter dados para uma avaliação comparativa ou um controle de qualidade. Supõe-se que sejam indicativos do desempenho dos materiais quando em condições práticas. A execução de testes mecânicos não significa a abolição das pesquisas clínicas, porém, só será conveniente atingir esta fase com aqueles materiais que mostraram-se promissores quando do estudo das suas propriedades in vitro ${ }^{11}$.

Vários são os ensaios mecânicos empregados para simular os esforços reais a que as restaurações são submetidas, visando prever o desempenho dos materiais nas diferentes situações. Assim, por exemplo, segundo BAN; ANUSAVICE ${ }^{10}$ a resistência à tração em materiais frágeis é mais expressiva do que a resistência à compressão por avaliar melhor o potencial de falhas das restaurações.

OILO ${ }^{68}$ salientou a importância da utilização dos testes de resistência adesiva em pesquisas laboratoriais. Segundo ele o objetivo dos testes de resistência seria fraturar ou romper a interface de um corpo-de-prova tentando estabelecer um parâmetro ou valor que demonstrasse a força de adesão, permitindo a realização de um estudo comparativo entre os grupos experimentais.

A falta de uma metodologia simples e bem padronizada, bem como o desconhecimento de fatores que podem influir significantemente nos valores de resistência colhidos pelo uso de diferentes testes mecânicos podem acarrretar discrepância de resultados entre diferentes grupos de pesquisadores. Por este motivo a escolha do tipo de ensaio para testar a resistência de uniões tem evoluído. 
O teste de resistência ao cisalhamento foi largamente criticado após estudo realizado por DELLA BONA; VAN NOORT ${ }^{30}$ que questionaram a eficácia do mesmo demostrando que espécimes que tinham a mesma interface adesiva e o mesmo desenho geométrico, mas com configurações diferentes apresentavam resistência diferente ao teste de cisalhamento. Segundo os autores a distribuição das tensões internas na maioria das vezes estava presente principalmente no corpo do espécime e não na área de adesão propriamente dita.

Para sanar estes problemas surgiu em 1994 um teste de tração que, pelas dimensões do corpo-de-prova foi denominado de "micro-tração"78. Com ele é possível obter vários espécimes partindo de um mesmo substrato; além de não apresentar as variáveis descritas anteriormente que ocorrem com o teste de resistência ao cisalhamento.

De acordo com OILO $^{68}$ existem três fatores, além das características inerentes do material testado, que podem interferir no resultado dos testes de resistência: o tipo de material testado, a qualidade do substrato e meio de armazenagem dos corpos-de-prova.

O armazenamento dos corpos-de-prova de resina em água previamente à confecção dos reparos tem sido utilizado com frequência ${ }^{36}$ para simular 0 envelhecimento do substrato. Os resultados obtidos demonstram que a resistência dos espécimes reparados após armazenamento em água é menor que a exibida por amostras reparadas sem armazenamento. A redução da resistência adesiva dos reparos confeccionados após o envelhecimento simulado da resina, pode estar relacionada à quantidade de radicais livres presentes na superfície do substrato. Segundo INOUE; HAYASHI ${ }^{48}$ a ocorrência do monômeros insaturados 
pode diminuir em até dez vezes após armazenamento de corpos-de-prova de resina composta por treze dias em água, quando comparada à quantidade de monômeros presentes logo após a polimerização.

VANKERCKHOVEN et al. ${ }^{92}$ estudaram o efeito de vários parâmetros sobre a quantidade de grupos metacrilato não reagidos nas superfícies de resinas compostas e concluíram que quaisquer tipos de tratamento e variáveis de manipulação reduzem significantemente o número de radicais livres na superfície. RUYTER; SWENDSEN ${ }^{77}$ afirmam que esta quantidade pode estar diretamente relacionada à composição das resinas, o que justificaria a variabilidade dos resultados encontrados na literatura.

Segundo FERRACANE; MARKER ${ }^{36}$ os efeitos do envelhecimento simulado da resina em solução aquosa estão diretamente relacionados à sua composição. Parece que as resinas quando armazenadas por longos períodos sofrem uma dissolução hidrolítica. SÖDERHOLM et al.$^{86}$ verificaram existir uma correlação entre a dissolução de íons e a formação de trincas em todos os materiais testados, com exceção de uma resina de micropartículas. Esta correlação foi explicada pela suposição que as trincas provém da formação de pressão osmótica em espaços pré-existentes no interior da resina resultantes da degradação provocada pelo acúmulo de água e pela constante liberação de componentes das partículas de carga.

Outro meio de armazenagem que poderia ser utilizado seria a saliva artificial $^{32,34,58}$. DHURU; LLOYD $^{32}$ observaram que a lavagem com água e a secagem da superfície dos espécimes após os mesmos permanecerem armazenados em saliva artificial durante uma hora não foi capaz de remover a 
contaminação totalmente. Seria portanto mais uma variável a ser considerada para obtenção dos resultados.

Nota-se que são vários os fatores que podem influenciar a adesão entre resinas compostas. Dentre eles, SAUNDERS ${ }^{80}$ destacou a capacidade de molhamento do material adicionado sobre a superfície do substrato, o efeito do tratamento de superfície previamente a realização do reparo, a quantidade e a capacidade de reatividade química da matriz orgânica disponível para adesão. Há evidências na literatura ${ }^{58}$ que quanto maior a quantidade de matriz orgânica disponível, melhor será a adesão. Isto explica os dados obtidos em vários estudos $^{9,15,23,63}$ que demostram um maior valor de resistência para as resinas de micropartículas quando comparadas com as resinas com maior quantidade e/ou tamanho de partículas de carga.

Para este estudo foi empregada a resina composta Tetric Ceram (VIVADENT, Schaan - Liechtenstein), que é indicada tanto para restaurações diretas em dentes anteriores e posteriores, quanto para reparos de: próteses metalo-cerâmicas, metalo-plásticas, restaurações indiretas de cerâmica, de resinas laboratoriais e de compósitos de inserção direta. Trata-se portanto de um material odontológico multi-uso ainda pouco estudado e justamente por isto foi escolhido.

\subsection{Dos tratamentos das superfícies para reparo:}

O fenômeno da adesão está envolvido em várias situações na Odontologia, principalmente quando estudamos e preconizamos procedimentos de reparos em restaurações de resinas compostas. 
Quando duas substâncias são postas em contato íntimo uma com a outra, as moléculas de um substrato aderem ou são atraídas pelas moléculas do outro substrato.. Esta força é denominada adesão quando moléculas dissimilares são atraídas e coesão quando moléculas do mesmo tipo são atraídas. O material ou película adicionada para produzir a adesão é conhecida como adesivo, enquanto o material ao qual este é aplicado é denominado aderente ${ }^{6}$.

Uma forte aderência de um substrato ao outro pode ser obtida por intermédio de adesão mecânica ou retenção em vez de atração molecular. A adesão mecânica pode envolver mecanismos sutis, como a penetração do adesivo em irregularidades microscópicas na superfície do substrato.

Outros fatores a serem considerados são a energia de superfície e a capacidade de molhamento do adesivo sobre o substrato. Para a existência da adesão as superfícies devem-se atrair uma à outra na sua interface e o aumento de energia por unidade de área de superfície é referido como energia de superfície ou de tensão superficial. Quanto maior a energia da superfície, maior será a capacidade de adesão.

Sobre a capacidade de molhamento diz-se que um líquido é capaz de "molhar" um sólido quando o ângulo formado entre eles é menor que 90 graus. 0 molhamento ideal é conseguido quando a tensão superficial do líquido é igual ou ligeiramente menor que a energia livre do substrato sólido.

Observando os resultados obtidos vimos que as resistências de todos os reparos foram significantemente menores que a resistência coesiva do material. Uma série de trabalhos encontrados na literatura estão em consonância com estes resultados $^{9,15,19,26,29,63,72,73,74,84,85,87 .}$ 
O tratamento de superfície que demonstrou significantemente menor eficiência foi o condicionamento com ácido hidrofluorídrico. Alguns trabalhos na literatura apontam o ácido hidrofluorídrico como um agente ineficaz para os procedimentos de reparo em resina ${ }^{17,88,89}$. Para SWIFT JÚNIOR et al. ${ }^{89}$ a utilização do ácido hidrofluorídrico reduz significantemente a resistência dos espécimes reparados, mesmo quando precedido de abrasionamento com óxido de alumínio e seguido de silanização. Os autores relatam que o ácido hidrofluorídrico ataca as partículas de vidro dos compósitos, resultando muitas vezes na dissolução total de todas as partículas expostas. Segundo BROSH et $\mathrm{al}^{17}$. e SWIFT JÚNIOR; LE VALLEY; BOYER ${ }^{88}$, o ácido hidrofluorídrico não aumenta de modo significante a resistência de reparos, na verdade, afeta adversamente o reparo em alguns compósitos, não devendo ser recomendado para uso rotineiro neste tipo de procedimento, especialmente onde a composição da resina a ser reparada for desconhecida.

Os resultados obtidos pelos espécimes tratados com ácido hidrofluorídrico neste trabalho parecem estar associados justamente à dissolução total ou em grandes proporções da fase inorgânica da resina composta, que afeta de maneira substancial a adesão entre os substratos. Pela observação e comparação das letras A e B da figura 11 notamos claramente as conseqüências desta dissolução na superfície do compósito em estudo. 

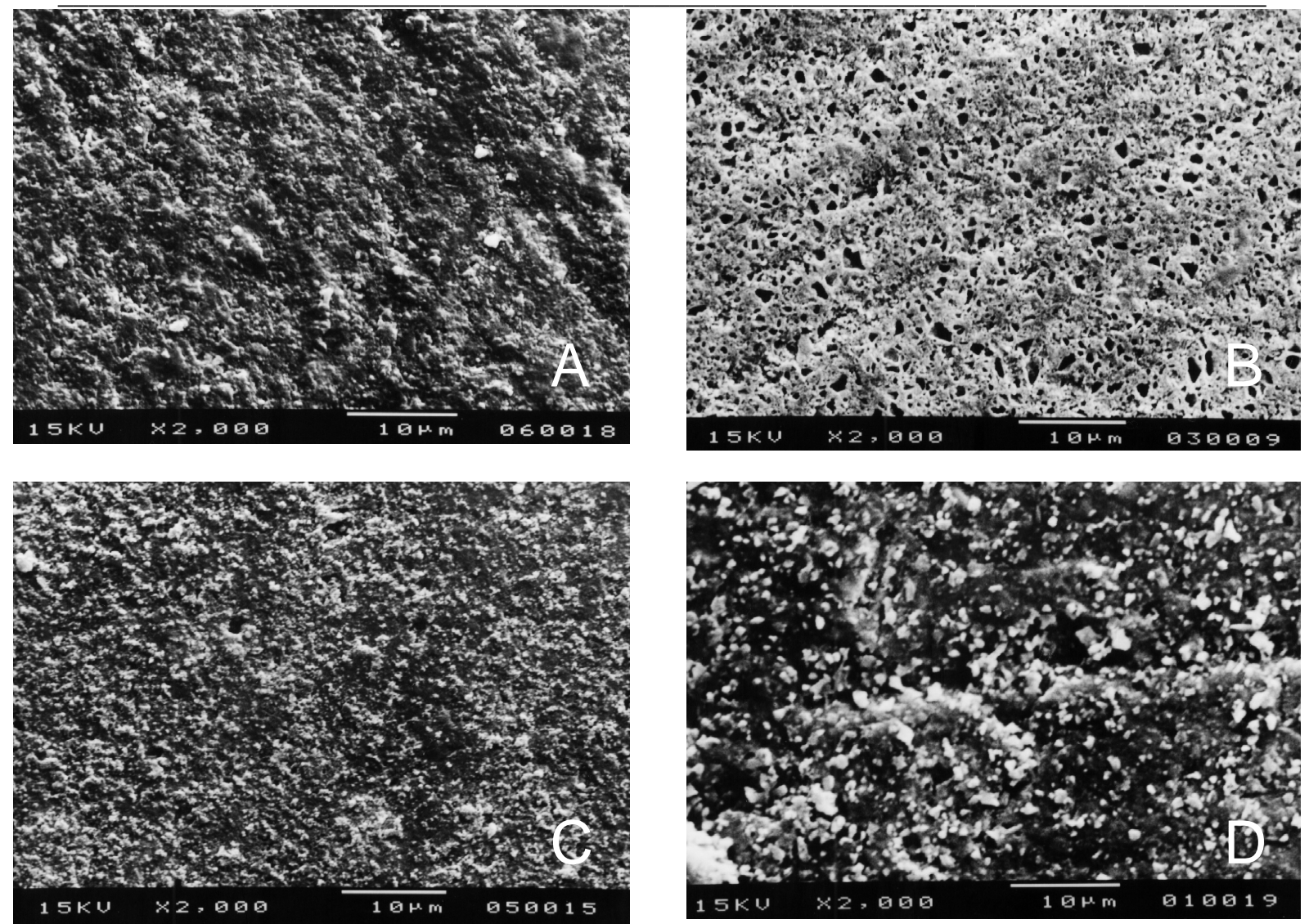

Figura 11: Fotomicrografias das superfícies de resina composta Tetric

Ceram após tratamento com: A - lixas abrasivas; B - ácido hidrofluorídrico a $10 \%$ durante 60 segundos; C - ácido fosfórico a $37 \%$ durante 30 segundos; D - jateamento com partículas de óxido de alumínio de $50 \mu \mathrm{m}$ durante 10 segundos.

Os grupos tratados com jateamento de partículas de óxido de alumínio apresentaram resultados médios semelhantes entre si, porém não resultaram na maior resistência à tração dentre todos os tratamentos executados. Contrariamente, alguns trabalhos encontrados na literatura apontam o jateamento 
com partículas de óxido de alumínio como o tratamento de maior resistência à tração nos procedimentos de reparo em resina ${ }^{39,}{ }^{89}$. Alguns autores como FREITAS $^{39}$, SWIFT JÚNIOR; LE VALLEY; BOYER $^{88}$ e TURNER; MEIERS ${ }^{91}$ visualizaram ao microscópio a presença de porosidades na superfície jateada. E segundo estes autores estas porosidades em grande número seriam responsáveis pela principal força de adesão apresentada pelos espécimes.

Comparando as letras A e D da figura 11 notamos, na letra $D$, a presença de uma série de partículas na superfície do compósito. Tudo indica que são partículas de óxido de alumínio que permaneceram sobre a referida superfície mesmo depois do procedimento de lavagem. A presença de tais partículas causa a obliteração das porosidades produzidas, dificultando a atuação e penetração do agente silanizador e/ou do sistema adesivo e o íntimo contato entre a resina envelhecida e a resina de reparo, o que acarreta e justifica a menor resistência à tração encontrada neste trabalho quando comparado a outros citados anteriormente.

Tornam-se pertinentes a execução de maiores estudos referentes ao emprego do jateamento de óxido de alumínio nos procedimentos de reparo em restaurações de resina composta, levando-se em consideração alguns fatores que podem influenciar este procedimento como: pressão, tamanho e formato das partículas, ângulo e distância com os quais o jateamento é realizado.

Os silanos são agentes anfóteros ou bi-funcionais, que podem reagir com diferentes superfícies, uma inorgânica e outra orgânica ${ }^{2}$. Deste modo, quando propomos a utilização deste material em procedimentos de reparo de compósitos, esperamos que haja uma provável ligação química entre a matriz inorgânica da 
resina envelhecida e a matriz orgânica da resina de reparo. Em um estudo realizado por SÖDERHOLM ${ }^{84}$ o grupo de amostras tratadas com silano apresentou resistência superior aos demais grupos, além de ter sido o menos afetado pela exposição à água após 6 meses de armazenamento. A alta resistência adesiva dos reparos promovidos com silano foi explicada pela sua capacidade de remoção da camada orgânica depositada na superfície, combinada com o tratamento químico do próprio silano sobre as partículas de carga expostas.

Segundo MATSUMURA; HISAMATSU; ATSUTA $^{59}$ de um modo geral a resistência ao cisalhamento de amostras reparadas, onde um agente silanizador foi empregado, aumenta com o transcorrer do tempo de armazenagem.

O componente principal encontrado no agente silanizador empregado neste estudo é o 3-Metacriloxipropil-trimetoxisilano, que apresenta compatibilidade com os dimetacrilatos das resinas compostas. A quebra da molécula do referido componente resulta na formação de silanóis, parte ativa dos silanos, os quais possuem grande afinidade por ligações secundárias não específicas com superfícies hidratadas, ou seja, são capazes de estabelecerem a formação de pontes de hidrogênio com moléculas de água absorvidas na superfície das resinas compostas armazenadas em água ${ }^{5}$.

Não há um consenso a respeito do mecanismo de adesão promovido pelos agentes silanizadores. A teoria mais aceita atualmente parece ser a do mecanismo de adesão hidrolítica reversível. Esta teoria basea-se na quebra reversível e restabelecimento das ligações entre o agente silano e o substrato, sem a ruptura definitiva da ligação. Tal adesão é obtida na presença de água, a 
qual forma um equilíbrio dinâmico com os silanóis ativos. Portanto as ligações são simultaneamente quebradas e restabelecidas na interface ${ }^{5}$.

Neste estudo os espécimes silanizados e seguidos da aplicação do sistema adesivo, juntamente com os espécimes tratados com ácido fosfórico e com também posterior aplicação do sistema adesivo, foram os que apresentaram de maneira estatisticamente significante os maiores valores de resistência à tração em relação a todos os demais procedimentos reparadores.

Os resultados dos espécimes tratados com silano e adesivo neste trabalho parecem estar associados a dois fatores distintos: a ocorrência de ligações químicas efetivas, facilitadas pelo longo tempo de armazenamento, entre as partículas de carga da resina antiga e a matriz orgânica da resina de reparo; e o aumento do molhamento da matriz resinosa proporcionado pelo agente silanizador empregado, o que facilitou a penetração e a ação do sistema adesivo.

O tratamento superficial com ácido fosfórico foi introduzido neste trabalho face ao grande emprego do mesmo no cotidiano dos cirurgiões-dentistas, bem como a parca utilização rotineira de um dispositivo de jateamento intra-oral na maioria dos consultórios e também pelo desconhecimento que a maioria dos profissionais apresentam em relação ao ácido hidrofluorídrico.

Como salientado anteriormente, a combinação do condicionamento com ácido fosfórico da superfície da resina composta seguida da aplicação do sistema adesivo também destacou-se de maneira estatisticamente significante em relação aos demais tratamentos reparadores. 
Outras investigações demonstram que o tratamento com ácido fosfórico seguido de adesivo ou agente de união não é capaz de aumentar a resistência adesiva dos reparos ${ }^{39,42,72,86,90}$.

Para SÖDERHOLM ${ }^{84}$ o ácido fosfórico atua como agente de limpeza superficial da resina a ser reparada, com maior efetividade em superfícies desgastadas com procedimentos que não geram calor, como a planificação abundante em água com lixas de granulação 400 e 600 empregadas neste trabalho.

Os resultados obtidos neste trabalho, com a conjugação do ácido fosfórico e do sistema adesivo, parecem estar pautados pelo poder de limpeza superficial atribuído ao agente condicionante (letra C, figura 11). Esta limpeza da superfície permite melhor escoamento e penetração do sistema adesivo, aumentado os valores de resistência à tração das restaurações reparadas.

Outro fator que pode ter contribuído para a obtenção de tais resultados deve-se ao aumento da energia livre de superfície que ocorre após o condicionamento com ácido fosfórico. O sistema adesivo, consequentemente a este aumento de energia livre de superfície, apresenta maior capacidade de molhamento o que proporciona um processo de adesão mais eficaz ${ }^{6}$.

A conjugação do condicionamento com ácido fosfórico, seguida da aplicação do agente silano e posteriormente do sistema adesivo (grupo I) produziu valores significativamente menores em relação aos grupos II e VII deste trabalho.

A limpeza superficial produzida pelo ácido fosfórico pode ter removido algumas partículas de carga da resina envelhecida, o que prejudica a atuação do agente silanizador pois diminui o número de ligações químicas entre a porção 
inorgânica da resina a ser reparada e a porção orgânica da resina de reparo. Os valores apresentados pelo grupo I podem ter ocorrido devido a este comportamento.

A simples aplicação do sistema adesivo não resultou em valores significantemente maiores em relação aos grupos II e VII. Este dado corrobora com a necessidade e preparação adequada da superfície resinosa para posterior aplicação do sistema adesivo. A limpeza da superfície, o aumento da sua energia livre e a presença de porosidades superficiais são importantes para a eficácia do sistema adesivo nos procedimentos de reparos de resina composta.

Nota-se que as condições ideais para adesão entre camadas de compósitos pode variar de acordo com os materiais empregados e que os mecanismos envolvidos neste processo são bem complexos. Levando-se em consideração as mais diversas variáveis presentes na cavidade bucal torna-se prudente recomendar a realização de retenções mecânicas adicionais com brocas ou pontas diamantadas previamente à realização dos reparos de resinas compostas. 
7. CONCLUSÕES 


\section{CONCLUSÕES:}

Com base na metodologia proposta e nos resultados obtidos nos testes de resistência à micro-tração pode-se concluir que:

$\checkmark$ os espécimes que não foram reparados apresentaram resistência à tração estatisticamente mais elevada em relação aos reparados independentemente do tratamento superficial empregado sobre os últimos;

$\checkmark$ quando comparamos apenas os espécimes que sofreram reparos destacam-se dois grupos: o grupo que envolveu o emprego do ácido fosfórico e posterior inserção do sistema adesivo e outro que empregou o agente silanizador seguida da aplicação do sistema adesivo. Ambos apresentaram resultados estatisticamente semelhantes e foram significativamente mais elevados que os demais tratamentos de superfície;

$\checkmark$ os grupos que empregaram o ácido hidrofluorídrico como agente condicionador apresentaram estatisticamente os mais baixos resultados em relação aos demais tratamentos superficiais efetuados. 
ANEXOS 


\section{ANEXOS}

Anexo 1 - Resultados originais e respectivos valores das áreas e das resistências adesivas dos testes de resistência à micro-tração do grupo I.

\begin{tabular}{c|c|c|c}
\hline ÁREA $-\mathbf{c m}^{2}$ & $\mathbf{K g f}$ & $\mathbf{K g} / \mathbf{c m}^{\mathbf{2}}$ & $\mathbf{M P a}$ \\
\hline 0.003 & 1.476 & 492.00 & 48.27 \\
0.003 & 1.445 & 481.67 & 47.25 \\
\hline 0.003 & 1.516 & 505.33 & 49.57 \\
\hline 0.003 & 1.407 & 469.00 & 46.00 \\
\hline 0.003 & 1.437 & 479.00 & 47.00 \\
\hline 0.003 & 1.394 & 464.67 & 45.58 \\
\hline 0.003 & 1.507 & 502.33 & 49.28 \\
\hline 0.003 & 1.586 & 528.67 & 51.86 \\
\hline 0.003 & 1.406 & 468.67 & 45.98 \\
\hline 0.003 & 1.475 & 491.67 & 48.23 \\
\hline 0.003 & 1.493 & 497.67 & 48.82 \\
\hline 0.003 & 1.576 & 525.33 & 51.54 \\
\hline 0.003 & 1.449 & 483.00 & 47.38 \\
\hline 0.003 & 1.477 & 492.33 & 48.30 \\
\hline 0.003 & 1.554 & 518.00 & 50.82 \\
\hline 0.003 & 1.422 & 474.00 & 46.50 \\
\hline 0.003 & 1.402 & 467.33 & 45.85 \\
\hline 0.003 & 1.41 & 470.00 & 46.11 \\
\hline 0.003 & 1.418 & 472.67 & 46.37 \\
\hline 0.003 & 1.529 & 509.67 & 50.00 \\
\hline & & &
\end{tabular}


Anexo 2 - Resultados originais e respectivos valores das áreas e das resistências adesivas dos testes de resistência à micro-tração do grupo II.

\begin{tabular}{|c|c|c|c|}
\hline ÁREA $-\mathrm{cm}^{2}$ & Kgf & $\mathrm{Kg} / \mathrm{cm}^{2}$ & $\mathrm{MPa}$ \\
\hline 0.003 & 1.935 & 645 & 63.28 \\
\hline 0.003 & 1.985 & 661.67 & 64.91 \\
\hline 0.003 & 1.966 & 655.33 & 64.29 \\
\hline 0.003 & 1.888 & 629.33 & 61.74 \\
\hline 0.003 & 2.098 & 699.33 & 68.61 \\
\hline 0.003 & 1.88 & 626.67 & 61.48 \\
\hline 0.003 & 1.865 & 621.67 & 61.00 \\
\hline 0.003 & 1.867 & 622.33 & 61.05 \\
\hline 0.003 & 2.015 & 671.67 & 65.90 \\
\hline 0.003 & 1.932 & 644.00 & 63.18 \\
\hline 0.003 & 1.914 & 638.00 & 62.60 \\
\hline 0.003 & 1.935 & 645.00 & 63.28 \\
\hline 0.003 & 1.952 & 650.67 & 63.83 \\
\hline 0.003 & 1.901 & 633.67 & 62.16 \\
\hline 0.003 & 1.882 & 627.33 & 61.54 \\
\hline 0.003 & 1.905 & 635.00 & 62.30 \\
\hline 0.003 & 1.903 & 634.33 & 62.23 \\
\hline 0.003 & 1.969 & 656.33 & 64.40 \\
\hline 0.003 & 2.069 & 689.67 & 67.66 \\
\hline 0.003 & 1.946 & 648.67 & 63.63 \\
\hline
\end{tabular}


Anexo 3 - Resultados originais e respectivos valores das áreas e das resistências adesivas dos testes de resistência à micro-tração do grupo III.

\begin{tabular}{c|c|c|c}
\hline ÁREA $-\mathbf{c m}^{2}$ & $\mathbf{K g f}$ & $\mathbf{K g ~} / \mathbf{~ c m}^{2}$ & $\mathbf{M P a}$ \\
\hline 0.003 & 0.9153 & 305.10 & 30.00 \\
\hline 0.002 & 0.567 & 283.50 & 27.81 \\
\hline 0.002 & 0.6854 & 342.70 & 33.62 \\
\hline 0.003 & 0.9254 & 308.47 & 30.26 \\
\hline 0.003 & 0.7363 & 245.43 & 24.07 \\
\hline 0.002 & 0.5470 & 273.50 & 26.83 \\
\hline 0.003 & 0.7581 & 252.7 & 24.79 \\
\hline 0.003 & 0.8222 & 274.07 & 27.00 \\
\hline 0.003 & 0.8767 & 292.23 & 28.67 \\
\hline 0.003 & 0.8670 & 289.00 & 28.35 \\
\hline 0.003 & 0.8202 & 273.40 & 26.82 \\
\hline 0.003 & 0.9723 & 324.10 & 31.79 \\
\hline 0.003 & 0.8673 & 289.10 & 28.36 \\
\hline 0.002 & 0.5723 & 286.15 & 28.07 \\
\hline 0.003 & 0.8440 & 281.33 & 27.60 \\
\hline 0.003 & 0.8164 & 272.13 & 26.70 \\
\hline 0.003 & 0.8941 & 298.03 & 29.24 \\
\hline 0.003 & 0.8091 & 269.70 & 26.46 \\
\hline 0.003 & 0.8858 & 295.27 & 28.97 \\
\hline 0.003 & 0.78 & 260.00 & 26.00 \\
\hline
\end{tabular}


Anexo 4 - Resultados originais e respectivos valores das áreas e das resistências adesivas dos testes de resistência à micro-tração do grupo IV .

\begin{tabular}{c|c|c|c}
\hline ÁREA $-\mathbf{c m}^{2}$ & $\mathbf{K g f}$ & $\mathbf{K g} / \mathbf{~ c m}^{2}$ & $\mathbf{M P a}$ \\
\hline 0.003 & 0.8615 & 287.17 & 28.17 \\
\hline 0.003 & 0.8420 & 280.67 & 27.53 \\
\hline 0.003 & 0.8906 & 296.87 & 29.12 \\
\hline 0.003 & 0.7072 & 235.73 & 23.12 \\
\hline 0.003 & 0.729 & 243.00 & 23.84 \\
\hline 0.003 & 0.8731 & 291.03 & 29.00 \\
\hline 0.003 & 0.7890 & 263.00 & 25.80 \\
\hline 0.003 & 0.9037 & 301.23 & 30.00 \\
\hline 0.003 & 0.8222 & 274.07 & 27.00 \\
\hline 0.003 & 0.8047 & 268.23 & 26.31 \\
\hline 0.003 & 0.7421 & 247.37 & 24.27 \\
\hline 0.003 & 0.8779 & 292.63 & 28.71 \\
\hline 0.003 & 0.7989 & 266.30 & 26.12 \\
\hline 0.003 & 0.8228 & 274.27 & 26.91 \\
\hline 0.003 & 0.8089 & 269.63 & 26.41 \\
\hline 0.003 & 0.8147 & 271.57 & 26.64 \\
\hline 0.003 & 0.8058 & 268.60 & 26.35 \\
\hline 0.003 & 0.9037 & 301.23 & 30.00 \\
\hline 0.003 & 0.8585 & 286.17 & 28.07 \\
\hline 0.003 & 0.7677 & 255.90 & 25.10 \\
\hline
\end{tabular}


Anexo 5 - Resultados originais e respectivos valores das áreas e das resistências adesivas dos testes de resistência à micro-tração do grupo $\mathrm{V}$.

\begin{tabular}{c|c|c|c}
\hline ÁREA $-\mathbf{c m}^{2}$ & $\mathbf{K g f}$ & $\mathbf{K g ~} / \mathbf{c m}^{2}$ & $\mathbf{M P a}$ \\
\hline 0.003 & 1.416 & 472.00 & 46.30 \\
\hline 0.003 & 1.529 & 509.67 & 50.00 \\
\hline 0.003 & 1.411 & 470.33 & 46.14 \\
\hline 0.003 & 1.458 & 486.00 & 48.00 \\
\hline 0.003 & 1.416 & 472.00 & 46.30 \\
\hline 0.003 & 1.436 & 478.67 & 47.00 \\
\hline 0.003 & 1.449 & 483.00 & 47.38 \\
\hline 0.003 & 1.466 & 488.67 & 47.93 \\
\hline 0.003 & 1.385 & 461.67 & 45.29 \\
\hline 0.003 & 1.426 & 475.33 & 46.63 \\
\hline 0.003 & 1.419 & 473.00 & 46.40 \\
\hline 0.003 & 1.437 & 479.00 & 47.00 \\
\hline 0.003 & 1.507 & 502.33 & 49.28 \\
\hline 0.003 & 1.521 & 507.00 & 49.74 \\
\hline 0.003 & 1.363 & 454.33 & 44.57 \\
\hline 0.003 & 1.518 & 506.00 & 49.64 \\
\hline 0.003 & 1.579 & 526.33 & 51.63 \\
\hline 0.002 & 1.044 & 522.00 & 51.21 \\
\hline 0.003 & 1.588 & 529.33 & 51.93 \\
\hline 0.003 & 1.458 & 486.00 & 48.00 \\
\hline
\end{tabular}


Anexo 6 - Resultados originais e respectivos valores das áreas e das resistências adesivas dos testes de resistência à micro-tração do grupo VI.

\begin{tabular}{c|c|c|c}
\hline ÁREA $-\mathbf{~ c m}^{2}$ & $\mathbf{K g f}$ & $\mathbf{K g} / \mathbf{c m}^{\mathbf{2}}$ & $\mathbf{M P a}$ \\
\hline 0,003 & 1.467 & 489,00 & 47,97 \\
\hline 0,002 & 1.069 & 534,50 & 52,43 \\
\hline 0,002 & 1.065 & 532,50 & 52,24 \\
\hline 0,003 & 1.329 & 443,00 & 43,46 \\
0,003 & 1.329 & 443,00 & 43,46 \\
\hline 0,002 & 1.063 & 531,50 & 52,14 \\
\hline 0,003 & 1.484 & 494,67 & 48,53 \\
\hline 0,003 & 1.576 & 525,33 & 51,53 \\
\hline 0,003 & 1.505 & 501,67 & 49,21 \\
\hline 0,003 & 1.612 & 537,33 & 52,71 \\
\hline 0,002 & 1.079 & 539.5 & 52,92 \\
\hline 0,003 & 1.506 & 502,00 & 49,27 \\
\hline 0,003 & 1.541 & 513,67 & 50,39 \\
\hline 0,003 & 1.400 & 466,67 & 45,78 \\
\hline 0,002 & 1.070 & 535,00 & 52,48 \\
\hline 0,003 & 1.459 & 486,33 & 47,71 \\
\hline 0,002 & 1.073 & 536,50 & 52,63 \\
\hline 0,003 & 1.505 & 501,67 & 49,21 \\
\hline 0,003 & 1.517 & 505,67 & 49,61 \\
\hline 0,003 & 1.571 & 523,67 & 51,37 \\
\hline
\end{tabular}


Anexo 7 - Resultados originais e respectivos valores das áreas e das resistências adesivas dos testes de resistência à micro-tração do grupo VII.

\begin{tabular}{c|c|c|c}
\hline ÁREA $-\mathbf{c m}^{2}$ & $\mathbf{K g f}$ & $\mathbf{K g} / \mathbf{c m}^{2}$ & $\mathbf{M P a}$ \\
\hline 0.003 & 1.925 & 641.68 & 63.00 \\
\hline 0.003 & 1.864 & 621.33 & 61.00 \\
\hline 0.003 & 1.811 & 603.68 & 59.22 \\
\hline 0.003 & 1.867 & 622.33 & 61.10 \\
\hline 0.003 & 1.974 & 658.00 & 64.55 \\
\hline 0.003 & 1.882 & 627.33 & 61.54 \\
\hline 0.003 & 1.782 & 594.00 & 58.27 \\
\hline 0.003 & 1.809 & 603.00 & 59.15 \\
\hline 0.003 & 1.876 & 625.33 & 61.34 \\
\hline 0.003 & 1.905 & 635.00 & 62.30 \\
\hline 0.003 & 1.879 & 626.33 & 61.44 \\
\hline 0.003 & 1.925 & 641.68 & 63.00 \\
\hline 0.003 & 1.851 & 617.00 & 60.53 \\
\hline 0.003 & 1.88 & 626.68 & 61.48 \\
\hline 0.003 & 1.858 & 619.33 & 60.76 \\
\hline 0.003 & 1.94 & 646.68 & 63.44 \\
\hline 0.003 & 1.876 & 625.33 & 61.35 \\
\hline 0.003 & 1.831 & 610.33 & 60.00 \\
\hline 0.003 & 1.873 & 624.33 & 61.25 \\
\hline 0.003 & 1.882 & 627.33 & 61.54 \\
\hline
\end{tabular}


Anexo 8 - Resultados originais e respectivos valores das áreas e das resistências adesivas dos testes de resistência à micro-tração do grupo VIII.

\begin{tabular}{c|c|c|c}
\hline ÁREA $-\mathbf{~ c m}^{2}$ & $\mathbf{K g f}$ & $\mathbf{K g} / \mathbf{~ c m}^{2}$ & $\mathbf{M P a}$ \\
\hline 0,003 & 1.406 & 468,67 & 46,00 \\
\hline 0,003 & 1.468 & 489,33 & 48,00 \\
\hline 0,002 & 1.096 & 548,00 & 53,76 \\
\hline 0,003 & 1.381 & 460,33 & 45,16 \\
0,003 & 1.267 & 422,33 & 41,43 \\
\hline 0,003 & 1.518 & 506,00 & 49,64 \\
\hline 0,003 & 1.449 & 483,00 & 47,38 \\
\hline 0,002 & 1.098 & 549,00 & 53,86 \\
\hline 0,002 & 1.087 & 543,50 & 53,31 \\
\hline 0,002 & 1.078 & 539,00 & 52,88 \\
\hline 0,002 & 1.075 & 537,50 & 52,73 \\
\hline 0,002 & 1.067 & 533,50 & 52,34 \\
\hline 0,002 & 1.069 & 534,50 & 52,43 \\
\hline 0,003 & 1.345 & 448,33 & 44,00 \\
\hline 0,003 & 1.444 & 481,33 & 47,22 \\
\hline 0,003 & 1.425 & 475,00 & 47,00 \\
\hline 0,003 & 1.659 & 553,00 & 54,25 \\
\hline 0,003 & 1.320 & 440,00 & 43,16 \\
\hline 0,003 & 1.347 & 449,00 & 44,05 \\
\hline 0,003 & 1.467 & 489,00 & 48,00 \\
\hline
\end{tabular}


Anexo 9 - Resultados originais e respectivos valores das áreas e das resistências adesivas dos testes de resistência à micro-tração do grupo IX.

\begin{tabular}{c|c|c|c}
\hline ÁREA $-\mathbf{c m}^{2}$ & $\mathbf{K g f}$ & $\mathbf{K g} / \mathbf{c m}^{2}$ & $\mathbf{M P a}$ \\
\hline 0.003 & 2.49 & 830.00 & 81.42 \\
\hline 0.003 & 2.468 & 822.67 & 80.70 \\
\hline 0.003 & 2.449 & 816.33 & 80.10 \\
\hline 0.003 & 2.453 & 817.67 & 80.21 \\
\hline 0.003 & 2.461 & 820.33 & 80.48 \\
\hline 0.003 & 2.442 & 814.00 & 80.00 \\
\hline 0.003 & 2.476 & 825.33 & 81.00 \\
\hline 0.003 & 2.473 & 824.33 & 81.00 \\
\hline 0.003 & 2.456 & 818.67 & 80.31 \\
\hline 0.003 & 2.525 & 841.67 & 82.57 \\
\hline 0.003 & 2.445 & 815.00 & 80.00 \\
\hline 0.003 & 2.502 & 834.00 & 81.81 \\
\hline 0.003 & 2.43 & 810.00 & 79.46 \\
\hline 0.003 & 2.507 & 835.67 & 82.00 \\
\hline 0.003 & 2.488 & 829.33 & 81.36 \\
\hline 0.003 & 2.422 & 807.33 & 79.20 \\
\hline 0.003 & 2.508 & 836.00 & 82.01 \\
\hline 0.003 & 2.472 & 824.00 & 80.83 \\
\hline 0.003 & 2.497 & 832.33 & 81.65 \\
\hline 0.003 & 2.509 & 836.33 & 82.04 \\
\hline
\end{tabular}




\section{REFERÊNCIAS}

\section{BIBLIOGRÁFICAS}




\section{REFERÊNCIAS BIBLIOGRÁFICAS}

1. AL EDRIS, A. et al. SEM evalutions of etch patterns by three etchants on three porcelains. J. prosth. Dent., v.64, n.6, p.734-9, Dec. 1990.

2. ALBERS, H.F. Esthetic treatment planning and pertinent information on cosmetic, adhesives and restorative dentistry. Adept Report, v.3, p. 345-52, Fall 1992.

3. AMERICAN DENTAL ASSOCIATION. Council on Dental Materials and Devices. Specification n. 27 for direct filling resins. J. Amer. Dent. Ass., v.94, n.6, p.1191-5, June 1977.

4. AMERICAN DENTAL ASSOCIATION. Council on Dental Materials and Devices. Specification n. 1 for alloy for dental amalgam. J. Amer. Dent. Ass., v. 95, n.3, p.614-7, Sept.1977.

5. ANAGNOStOPOULOS, T.; ELIADES, G.; PALAGHIAS, G. Composition reactivity and surface interactions of three dental silane primers. Dent. Mat., v.9, n.3, p. 182-90, May 1993.

6. ANUSAVICE, K.J. Phillips materiais dentários. 10 ed. Rio de Janeiro, Guanabara Koogan, 1998.

7. ARIETA, M.L. Avaliação da resistência de união de reparos realizados com resinas compostas. Bauru, 1989. 93p. Dissertação (Mestrado) Faculdade de Odontologia de Bauru, Universidade de São Paulo. 
8. ARITA, K. et al. Thermal influencing of the bond strength of repaired composites. J. dent. Res., v.70, p.392, 1991. Special issue. / Abstract n. $1010 /$

9. AZARBAL, P.; BOYER, D.B.; CHAN, K.C. The effect of bonding agents on interfacial bond strength of repaired composites. Dent. Mat., v.2, n.4, p.153-5, July 1986.

10. BAN, S.; ANUSAVICE, K.J. Influence of test method on failure stress of brittle dental materials. J. Dent. Res., v.69, n.12, p.1791-1799, Dec. 1990.

11. BIANCHI, JOEL. Estudo sobre a resostência à microtração em função das dimensões, modo de preensão e formato do corpo-0de-prova. São Paulo, 1999. 112p. Tese (Doutorado) - Faculdade de Odontobgia da Universidade de São Paulo.

12. BOWEN, R.L. Dental filling material comprising vinyl silane treated fused silica and a binder consisting of a reaction product of bisfenol and glycidyl acrylate. U.S.A. Patent n. 3066, p.112, Nov. 1962.

13. BOWEN, R.L. Properties of silica-reinforced polymer for dental restorations. J. Amer. Dent. Ass., v.66, n.1, p.57-64, Jan. 1963.

14. BOWEN, R.L.; REED, L.E. Semiporous reinforcing fillers for composite resins: II. Heat treatmentes and etching characteristics. J. dent. Res., v.55, n.5, p.748-56, Sept./Oct. 1976.

15. BOYER, D.B.; CHAN, K.C.; REINHARDT, J.W. Build-up and repair of lightcured composites: bond strength. J. dent. Res., v.63, n.10, p.1241-4, Oct. 1984. 
16. BOYER, D.B.; CHAN, K.C.; TORNEY, D.L. The strength of multilayer and repaired composite resin. J. prosth. Dent., v.39, n.1, p.63-7, Jan. 1978.

17. BROSH, T. et al. Effect of combinations of surface treatments and bonding agents on the bond strength of repaired composites. J. prosth. Dent., v.77, n.2, p.122-6, Feb. 1997.

18. BUSATO, A.L.S. ET AL. Dentística Restauradora em Dentes Posteriores. São Paulo: Artes Médicas, 1996.

19. CARNEIRO, C.T.P. et al. Influência do reparo na resistência à ruptura, por tração, de resinas compostas. Estomat \& Cult., v.11, n.1, p.1-12, jan.jun. 1977.

20. CAUSTON , B.E. Repair of abraded composite fillings. Brit. Dent. J., v. 139, n.7, p.286-8, Oct. 1975.

21. CESAR PF; ET AL Tensile bond strength of composite repairs on Artglass using different surface treatments. J. Dent., v.14, n.6, p.373-7, Dec, 2001.

22. CHALKLEY, Y.; CHAN, D.C. Microleakage between ligt-cured composites and repairs. J. prosth. Dent., v.56, n.441-4, Oct. 1986.

23. CHAN, K.C.; BOYER, D.B. Repair of conventional and microfilled composite resins. J. prosth. Dent. , v.50, n.3, p.345-50, Sept.1983.

24. CHIBA, K.; HOSODA, H.; FUSAYAMA, T. The addition of na adhesive composite resin to the same material: Bond strength and clinical techiniques. J. prosth. Dent., v.61, n.6, p.669-75, June 1989. 
25. CHIN, Y.H.; TYAS, M.J.; GOLDMAN, M. The bond strength of incrementally placed composite resins. Aust dent. J., v.32, n.4, p.247-51, Apr. 1987.

26. CONSANI, S.; STOLF, W.L.; RUNHNKE, L.A. Resistência à tração da resina composta com emenda. Ver. Ass. Paul. Cirurg. Dent., v.31, n.6, p.396-401, nov./dez. 1977.

27. CROLL, T.P. Repair of defective Class I composite posterior composites. Quintessence Int., v.21, n.9, p.695-8, Sept. 1990.

28. CRUMPLER, D.C. et al. Bonding to surfaced posterior composites. Dent. Mat., v.5, n.6, p.417-24, Nov. 1989.

29. DAVIES, R.B. et al. Strength of secondary-cured resin composite inlay repairs. Quintessence Int., v.28, n.6, p.415-9, June 1997.

30. DELLA BONA, A.; VAN NOORT, R. Shear vs. Tensile bond strength of resin composite bonded to ceramic. J. dent. Res., v.74, n.9, p.1591-6, Sept. 1995.

31. DELLA BONA, A. et al. Effect of sample design on resin to ceramic shear bond strengths. J. dent. Res., v.75, n.5, p.1089, May 1996. / Abstract n.90/

32. DHURU, V.B.; LLOYD, C.H. The fracture toughness of repair composite. J. oral Rehab., v.12, n.5, p.413-21, Sept. 1985.

33. ELI, I. et al. Sequentially light-cured composites: stegth of bond between layers. J. prosth. Dent., v.56, n.2, p.158-61, Aug. 1986. 
34. ELI, I. et. al. Bond strengths of joined posterior lightcured composites: comparisson of surface treatments. J. prosth. Dent. , v.60, n.2, p.185-9, Aug. 1988.

35. ELIADES, G.C.; CAPUTO, A.A. The strength of layering technique in visible ligth-cured composites. J. prosth. Dent. , v.61, n.1, p.31-8, Jan. 1989.

36. FERRACANE, J.L.; MARKER, V.A. Solvent degradation and reduced fracture toughness in aged composites. J. dent. Res. , v.71, n.1, p.13-9, Jan. 1992.

37. FORSTEN, L. Bond between subsequently added light activated composite resin and hardened material. Scand. J. dent. Res. , v.92, n.4, p.371-3, 1984.

38. FORSTEN, L.; VALIAHO, M. Transverse bond strength of restorative resins. Acta odonto. scand. , v.29, n.5, p.527-37, 1971.

39. FREITAS, AMANDA BEATRIZ DAHDAH ANICETO DE. Avaliação da estabilidade de reparos em resina composta por testes de tração e cisalhamento, utilizando diferentes tratamentos de superfície. Bauru, 2001. 150p. Dissertação (Mestrado) - Faculdade de Odontologia de Bauru, Universidade de São Paulo.

40. GORDAN, V.V.; et al. Teaching students the repair of resin-based composite restorations: a survey of North American dental schools. J. Amer. dent. Ass., v.134, n.3, p.317-23, Mar. 2003.

41. GREGORY, W.A.; POUNDER, B.; BAKUS, E. Bond strengths of chemically dissimilar repaired composite resins. J. prosth. Dent. , v.64, n.6, p.6648, Dec. 1990. 
42. GREGORY, W.A. et al. Physical properties and repair bond strength of direct and indirect composite resins. J. prosth. Dent., v.68, n.3, p.40611, Sept. 1992.

43. HAGGE, M.S.; LINDEMUTH, J.S.; JONES, A.G. Shear bond strength of bisacryl composite provisional material repaired with flowable composite. J. Esthet. Restor. Dent., v.14, n.1, p.47-52, 2002.

44. HISAMATSU, N.; ATSUTA, M; MATSUMURA, H. Effect of silane primers and unfilled resin bonding agents on repair bond strength of a prosthodontic microfilled composite. J. oral Rehab., v.29, n.7, p.644-8, July 2002.

45. HOLDER, R. et al.. Bonding agent composition effects on posterior composite repair strengths. J. dent. Res. , v.70, p.392, 1991. Special issue. / Abstract n. 1009/

46. HUNTER, A.R.; TREASURE, E.T.; HUNTER, A.J. Increases in cavity volume associated with the removal of class 2 amalgam and composite restorations. Oper .Dent., v.20, n.2, p.2-6, Jan./Feb.1995.

47. HULA, K.; NELSON, S.; THOMPSON, V. In vitro effect of APF gel on three composite resins. J. dent. Res. , v.62, n.7, p.846-9, July 1983.

48. INOUE, K.; HAYASHI, I. Residual monomer (Bis-GMA) of composite resins. J. oral Rehab., v.9, n.6, p.493-7, Nov. 1982.

49. KAO, E.C.; PRYOR, H.G.; JOHNSTON, W.M. Strength of composites repaired by laminating with dissimilar composites. J. prosth. Dent., v.60, n.3, p.328-33, Sept. 1988. 
50. KULA, K.; NELSON, S.; THOMPSON, V. In vitro effect of APG gel on three composite resins. J. dent. Res., v.62, n.7, p.846-9, July 1983.

51. KULA, K. et al. In vitro effect of acidulated phosphate fluoride gel on the surface of composites with different filler particles. J. prosth. Dent., v.56, n.2, p.161-9, Aug. 1986.

52. KUPIEC, K.A.; BARKMEIER, W.W. Laboratory evaluation of surface treatments for composite repair. Oper. Dent., v.21, n.2, p.59-62, Mar./Apr.1996.

53. KUPIEC, K.A.; SVENSON, R.R.; BARKMEIER, W.W. Laboratory evaluation of surface treatments for composite repair. J. dent. Res., v.76, p.378, 1997. Special issue. / Abstract n. 2919/

54. LACY, A.M. et al. Effect of porcelain surface treatment on the bond to composite. J. prosth. Dent., v.60, n.3, p.288-91, Sept. 1988.

55. LEWIS, G.; et al. Shear bond strength of immediately repaired light-cured composite resin restorations. Oper. Dent., v.23, n.3, p.121-7, Mar./Apr.1998.

56. LI, J. Effects of surface properties on bond strength between layers of newly cured dental composites. J. oral Rehab., v.24, n.5, p.358-60, May 1997.

57. LLOYD, C.H.; BAIGRIE, D.A.; JEFFREY, I.W. Tensile strength of composite repairs. J. Dent., v.8, n.2, p.171-7, 1980. 
58. LLOYD, C.H.; DHURU, V.B. Effect of a commercial bonding agent upon the fracture toughness of repaired heavily filled composite. Dent. Mat., v.1, n.3, p.83-5, June 1985.

59. MATSUMURA, H.; HISAMATSU, N.; ATSUTA, M. Effect of unfilled resins and a silane primer on bonding between layers of a light-activated composite resin veneering material. J. prosth. Dent. , v.73, n.4, p.38691, Apr. 1995.

60. MARTÍN, C.L; LÓPEZ, S.G; MONDELO, J.M.N.R. The effect of various surface treatments and bonding agents on the repaired strength of heattreated composites. J. prosth. Dent., v.86, n.5, p.481-8, Nov. 2001.

61. MEEKER, H.G.; HIRSCH, S.M.; KAIM, J.M. Repairing voids at cavosurfacecomposite resin margins. J. prosth. Dent., v.50, n.5, p.636-8, Nov. 1983.

62. MELO, RODRIGO. Resistência à traçäo de reparos em resina composta confeccionados sobre a resina de laboratório Artglass utilizandose diferentes tratamentos de superfície São Paulo, 2001. 71p. Dissertação (Mestrado) - Faculdade de Odontologia da Universidade de São Paulo

63. MIRANDA, F.J. et al. Interfacial bonding strengths of paired composite systems. J. prosth. Dent., v.51, n.1, p.29-32, Jan. 1984.

64. MITSAKI-MATSOU, $\mathrm{H}$. et al. $\mathrm{Na}$ in vitro study of the tensile strength of composite resins repaired with the same or another composite resin. Quintessence Int., v.22, n.6, p.475-81, June 1991. 
65. MJÖR, I.A. Repair versus replacement of failed restyorations. Int. dent. J., v.43, n.5, p.466-72, Oct. 1993.

66. MURREY, A.J. et al. Effect of resurfacing on additions to aged composite resins. J. dent. Res., v.61, p.302, 1982. Special issue. / Abstract $n$. $1112 /$

67. NAGEM FILHO, HALIM. Materiais Dentários Resinas Compostas. Bauru, 1999.

68. OILO, G. Bond strength testing: what does it mean? Int. dent. J., v.43, n.5, p.492-8, Oct. 1993.

69. PHILLIPS, R.W. Materiais dentários de Skinner. In: Resinas restauradoras. Rio de Janeiro, Guanabara, 1986. Cap. 14, p.155-77.

70. PHILLIPS, R.W., SWARTZ, M.L.; NORMAN, R.D. Restorative resins. In: Materials for the practicing dentist. Saint Louis, Mosby, 1969. Cap.11, p.172-94.

71. PODSHADLEY, A.G.; GULLET, C.E.; BINKLEY, T.K. Interface strength of incremental placement of visible light-cured composites. J. Amer. dent. Ass., v.110, n.6, p.932-4, June 1985.

72. POUNDER, B.; GREGORY, W.A.; POWERS, J.M. Bond strengths of repaired composite resins. Oper. Dent., v.12, p.127-31, 1987.

73. PUCKETT, A.D.; HOLDER, R.; O'HARA, J.W. Strength of posterior composite repairs using different composite/bonding agent combinations. Oper .Dent., v.16, n.4, p.136-40, July/Aug. 1991. 
74. REISBICK, M.H.; BRODSKY, J.F. Strength parameters of composite resins. J. prosth. Dent., v.26, n.2, p.178-85, Aug. 1971.

75. RESTAURADOR 3M Z100. Perfil Técnico. S.I., 3M, 1995.

76. ROULET, J.F.; SÖDERHOLM, K-J.M.; LONGMATE, J. Effects of treatment and storage conditions on ceramic / composite bond strength. J. dent. Res., v.74, n.1, p.381-7, Jan. 1995.

77. RUYTER, I.E.; SVENDSEN, S.A. Remaining methacrylate groups in composite restorative materials. Acta odont. Scand., v.36, n.2, p.75-81, Mar. 1978.

78. SANO, H.; SHONO, T.; SONODA, H.; TAKATSU, T.; CIUCCHI, B.; CARVALHO, R.; PASCHLEY, D.H. Relationship between surface area for adhesion and tensile bond strength - Evaluation of a microtensile bond test. Dent Mater, v.10, n.4, p.236-240, July 1994b.

79. SAU, C. W.; et al. Shear bond strength of repaired composite resins using a hybrid composite resin. Oper. Dent., v.24, n.3, p.156-61, May/June 1999.

80. SAUNDERS, W.P. Effect of fatigue upon the interfacial bond strength of repaired composite resins. J. Dent., v.18, n.3, p.158-62, June 1990.

81. SHAADAD, S.A.; KENNEDY, J.G. Bond strength of repaired anterior composite resins: na in vitro study. J. Dent., v.26, n.8, p.685-94, Nov. 1998.

82. SILVA E SOUZA JÚNIOR, M.H. Facetas laminadas em porcelana. MaxiOdonto, v.1, n.6, p.38-9, nov./dez. 1995. 
83. SMITH, D.C. Posterior composite resin dental restorative materials: materials development. In: VANHERLE, G.; SMITH, D.C. Posterior composite resin dental restorative materials. St. Paul, Minnesota Minning, 1985. P.47-60.

84. SÖDERHOLM, K.-J. Flexure stregth of repaired dental composites. Scand J. den. Res., v. 94, n.4, p.364-9, 1986.

85. SÖDERHOLM, K.-J.; ROBERTS, M.J. Variables influencing the repair strength of dental composites. Scand. J. dent. Res., v.99, n.2, p.17380, Apr. 1991.

86. SÖDERHOLM, K.-J. et al. Hydrolytic degradation of dental composites. J. dent. Res., v.63, n.10, p.1248-54, Oct. 1985.

87. SWITH JUNIOR, E.J.; CLOE, B.C.; BOYER, D.B. Effect of a silane-coupling agent on composite repair strengths. Amer. j. Dent., v.7, n.4, p.200-2, Aug. 1994.

88. SWITH JUNIOR, E.J.; LE VALLEY, B.D.; BOYER, D.B. Evaluation of new methods for composite repair. Dent. Mat., v.8, n.6, p.362-5, Nov. 1992.

89. SWITH JUNIOR, E.J. et al. Treatment of composite surfaces for indirect bonding. Dent. Mat., v.8, n.3, p.193-6, May 1992.

90. TJAN, A.H.; GLANCY, J.F. Interfacial bond strengths between layers of visible ligth-activated composites. J. prosth. Dent., v.59, n.1, p.25-9, Jan. 1988. 
91. TURNER, C.W.; MEIERS, J.C. Repair of na aged, contamined indirect composite resin with a direct, visible-ligth-cured composite resin. Oper.Dent., v.18, n.5, p.187-94, Sept./Oct. 1993.

92. VANKERCKHOVEN, $H$. et al. Unreacted methacrylate groups on the surfaces of composite resins. J. dent. Res., v.61, n.6, p.791-5, June 1982.

93. VAN NOORT, R. et al. A critique of bond strength measurements. J. Dent., v.17, n.2, p.61-7, Apr. 1989.

94. VAN NOORT, R. et al. The effect of local interfacial geometry on the measutement of the tensile bond strength to dentin. J. dent. Res., v.70, n.5, p.889-93, May 1991.

95. VON BEETZEN, M. et al. Factors influencing shear strength of incrementally cured composite resins. Acta odont. Scand., v.54, n.5, p.275-8, 1996.

96. YAFFE, A.; ZALKIND, M. The effect of topical application of fluoride on composite resin restaorations. J. prosth. Dent., v.45, n.1, p.59-62, Jan. 1981. 
ABSTRACT 


\section{ABSTRACT}

This study had as objective to evaluate the stability of repairs in resin composites, by means of application of traction forces (micro-tensile bond strength). In the moment of the repair, each group received a specific surface treatment: fosforic acid at $37 \%$, hidrofluoridric acid to $10 \%$ or sandblasted with particles of oxide of aluminum of $50 \mathrm{~mm}$. Such treatments were followed by the an associated adhesive agent's application or not to an silane agent. They were prepared specimens that didn't suffer any repair treatment and was the control group. The repaired specimens and not repaired were stored in water during 18 months. Elapsed this period specimens were then taken to an universal machine for resistance tests by traction. After analysis of results it could be verified that the specimens that didn't suffer any repair (control group) presented statistically superior resistance to traction in relation to the repaired independently of the superficial treatment employee on the last ones. It was although observed that the employment of fosforic acid and posterior use of adhesive system, as well as the use of the silane agent followed by the application of adhesive system, presented statistical similar results to each other and superior significantly in relation to the other repaired groups. The employment of the hidrofluoridric acid as conditioning agent resulted in the lowest resistance results to traction in relation to the other superficial treatments. 